UNIVERSIDADE DE BRASÍLIA

FACULDADE DE MEDICINA

PROGRAMA DE PÓS-GRADUAÇÃO EM MEDICINA TROPICAL

Juliana Soares de França

CARACTERÍSTICAS CLÍNICAS, EPIDEMIOLÓGICAS E LABORATORIAIS DA CRIPTOCOCOSE NO DISTRITO FEDERAL NO PERÍODO DE 2006 A 2013.

BRASÍLIA/DF 


\title{
CARACTERÍSTICAS CLÍNICAS, EPIDEMIOLÓGICAS E LABORATORIAIS DA CRIPTOCOCOSE NO DISTRITO FEDERAL NO PERÍODO DE 2006 A 2013.
}

\author{
Juliana Soares de França
}

Dissertação de Mestrado apresentada ao Programa de Pós-Graduação em Medicina Tropical da Faculdade de Medicina da Universidade de Brasília, como requisito parcial para obtenção do título de Mestre em Medicina Tropical.

Orientador: Prof. Dr. Vitor Laerte Pinto Junior

BRASÍLIA/DF

2015 
Ficha catalográfica elaborada automaticamente, com os dados fornecidos pelo(a) autor(a)

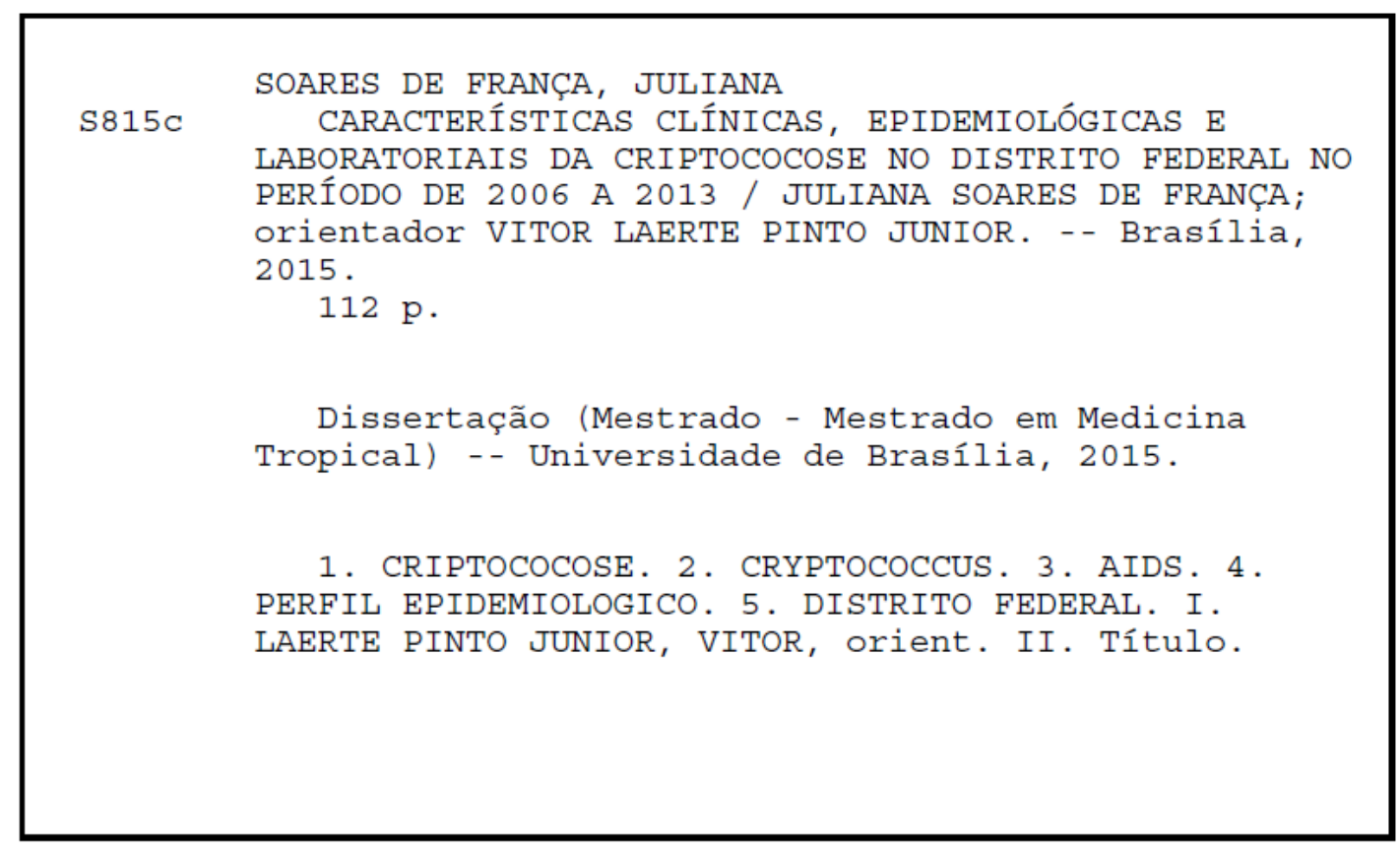


CARACTERÍSTICAS CLÍNICAS, EPIDEMIOLÓGICAS E LABORATORIAIS DA CRIPTOCOCOSE NO DISTRITO FEDERAL NO PERÍODO DE 2006 A 2013.

\section{UNIVERSIDADE DE BRASÍLIA}

\section{DATA DE DEFESA}

31 de Março de 2015

\section{BANCA EXAMINADORA}

Profa. Dra. Márcia dos Santos Lazera - Fundação Oswaldo Cruz- Instituto de Pesquisa Clínica Evandro Chagas

Prof. Dr. Gustavo Romero - Universidade de Brasília

Profa. Dra. Patrícia Albuquerque - Universidade de Brasília

Prof. Dr. André Moraes Nicola - Universidade de Brasília (Presidente) 


\section{DEDICATÓRIA}

Aos meus filhos João Pedro e Esther Vallentina... 


\section{AGRADECIMENTOS}

Primeiramente a Deus pelo dom da vida e por ter sido hoje e sempre o governador de tudo;

Ao meu orientador, Prof. Dr. Vitor Laerte Pinto Junior pela oportunidade, confiança depositada, paciência e apoio durante toda a trajetória do mestrado e que com certeza foram essenciais;

Aos professores do Núcleo de Pós Graduação em Medicina Tropical, em especial àqueles das disciplinas cursadas por transmitirem seus conhecimentos com muita clareza e precisão;

Aos professores, da Universidade Estadual de Montes Claros (UNIMONTES) em MG, Dra lara Soares de França e Dr. Rômulo Soares Barbosa, pela disponibilidade, dedicação e, sobretudo, amor, presentes desde os primeiros passos no mestrado, contribuindo para o meu crescimento na pesquisa com ensinamentos que com certeza serão para a vida toda;

A minha família pelo carinho incondicional e pela cumplicidade, em especial a minha irmã, pelas conversas, amizade e amor incondicional durante este percurso;

Ao meu esposo Fábio, pelo incentivo, sensibilidade, apoio, compreensão e suporte na criação dos nossos filhos quando precisei estar ausente para dedicação aos estudos;

À Universidade de Brasília e ao Núcleo de Medicina Tropical pelo acolhimento e oportunidade de qualificação;

Aos funcionários dos Núcleos de Arquivo Médico das unidades hospitalares visitadas, em especial aos responsáveis pelo Arquivo Médico do Hospital de Base do Distrito Federal e do Hospital Universitário de Brasília pelo apoio fundamental;

E a todos aqueles que por ventura não foram mencionados, mas que contribuíram em todas as etapas do meu trabalho.

Muito Obrigada!!! 


\section{LISTA DE TABELAS}

Tabela 1 - Fatores Relacionados à Virulência do Cryptococcus neoformans.

Tabela 2 - Recomendações de Tratamento Antifúngico para Meningoencefalite Criptocócica em indivíduos infectados pelo HIV 48

Tabela 3 - Recomendações de Tratamento Antifúngico para Meningoencefalite Criptocócica em pacientes humanos não infectados pelo

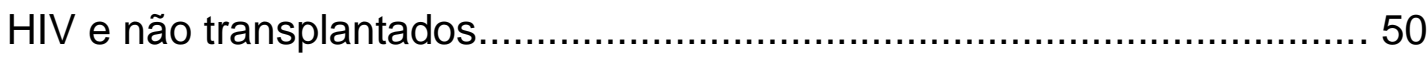

Tabela 4 - Recomendações de Tratamento Antifúngico para Criptococose Não Meníngea 51

Tabela 5- Sinais e sintomas clínicos presentes à admissão dos 87 casos de Criptococose. 74

Tabela 6 - Desfecho clínico dos pacientes com Criptococose associada à AIDS com contagem de CD4. 75

Tabela 7 - Associação entre sorologia para HIV X sexo X desfecho clínico 76 


\section{LISTA DE FIGURAS}

Figura 1- Ciclo de infecção por Cryptococcus spp................................ 28

Figura 2 - Modelo de disseminação de C. Neoformans.........................30

Figura 3 - Possíveis rotas utilizadas por C. neoformans para ultrapassar a barreira hematoencefálica

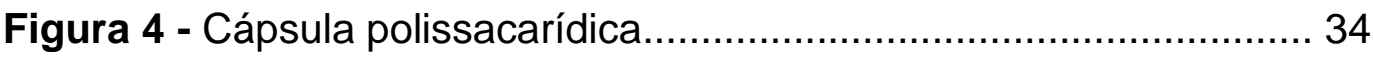

Figura 5 - Produção de Melanina por Cryptococcus neoformans........... 37

Figura 6 - Manejo da hipertensão intracraniana secundária a doença

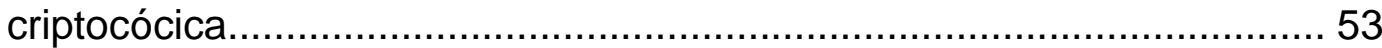

Figura 7 - Manejo da hipertensão intracraniana associada à

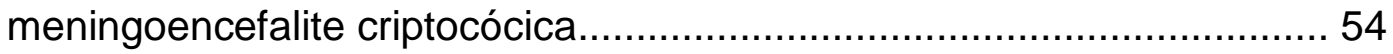




\section{LISTA DE GRÁFICOS}

Gráfico 1- Distribuição etária dos 87 pacientes acometidos pela Criptococose. 63

Gráfico 2 - Distribuição etária entre os casos de Criptococose ecom infecção pelo HIV 64

Gráfico 3 - Distribuição etária entre os casos de Criptococose sem infecção pelo HIV 64

Gráfico 4 - Naturalidade por Unidade Federativa entre os pacientes acometidos com Criptococose. 65

Gráfico 5 - Procedência por Regiões Administrativas entre os pacientes acometidos com Criptococose 67

Gráfico 6 - Desfecho Clínico segundo unidade de atendimento 71

Gráfico 7 - Ocupações entre os pacientes acometidos pela Criptococose..72 Gráfico 8 - Percentual de casos segundo ano de diagnóstico e status sorológico para HIV 73

Gráfico 9 - Desfecho clínico de pacientes com criptococose segundo status imunológico 76 


\section{LISTA DE MAPAS}

Mapa 1 - Distribuição dos casos segundo naturalidade por unidade

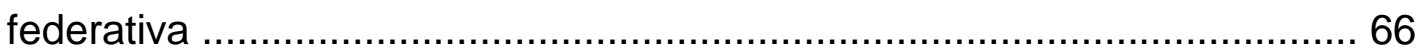
Mapa 2 - Distribuição dos casos segundo procedência no Distrito

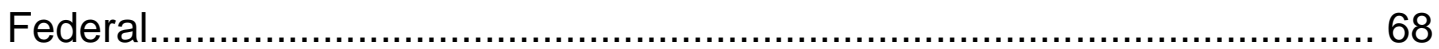

Mapa 3- Destino de atendimentos dos casos procedentes da região administrativa de Ceilândia............................................................. 69

Mapa 4- Destino de atendimentos dos casos procedentes da região administrativa de Taguatinga 69

Mapa 5- Distribuição dos casos segundoprocedência em cidades do Entorno do Distrito Federal. 70 


\section{LISTA DE ABREVIAÇÕES E SIGLAS}

AIDS Síndrome da Imunodeficiência Humana Adquirida

BHE Barreira Hemato - Encefálica

CDC Centros de Controle e Prevenção de Doenças

CEP Comitê de Ética em Pesquisa

Departamento de Micologia do Laboratório Central do Distrito Federal

DF Distrito Federal

Diretrizes Práticas para Tratamento da Doença Criptocóccica

DNA Ácido Dexorribonucleico

ESCS Escola de Ensino Superior em Ciências da Saúde do Distrito Federal

EUA Estados Unidos da América

FEPECS/ SES-DF Fundação de Ensino e Pesquisa em Ciências da Saúde

da Secretaria de Saúde do Distrito Federal

GALXM Galactoxilomanana

GXM Glucuronoxilomanana

HAART Highly Active Antiretroviral Therapy

HIC Hipertensão Intracraniana

HIV Imunodeficiência Humana

HBDF Hospital de Base do Distrito Federal

IRIS Reconstituição Imune Inflamatória

LACEN Laboratório Central de Saúde Pública

LCR Líquido Cefalorraquidiano

MA Macrófagos Alveolares Ativados

MAT Mating Type

MP Mananoproteinas

OMS Organização Mundial da Saúde

PCR Polymerase Chain Reaction

RNA ribonucleic Acid

SNC Sistema Nervoso Central 
Sociedade de Doenças Infecciosas dos Estados Unidos SUS Sistema Único de Saúde

UNB Universidade de Brasília 


\section{ÍNDICE}

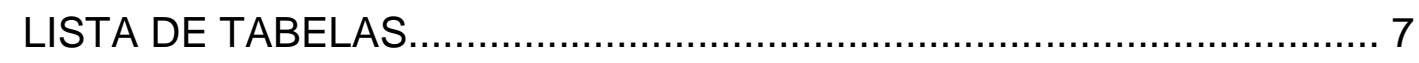

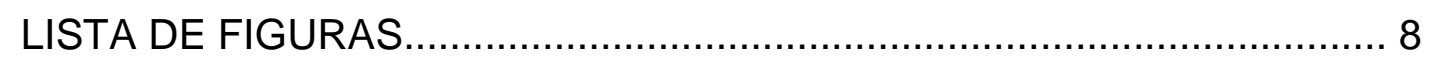

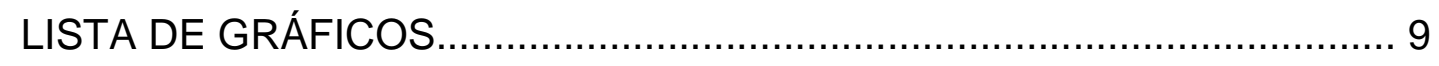

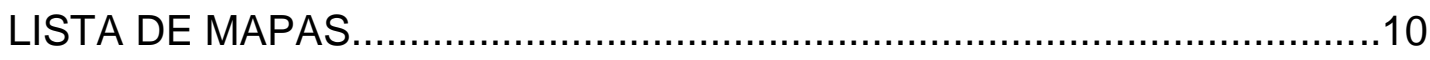

LISTA DE ABREVIAÇÕES E SIGLAS................................................ 11

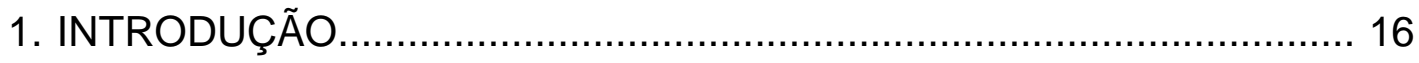

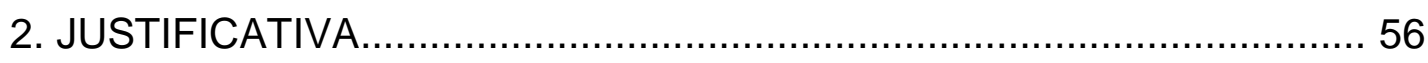

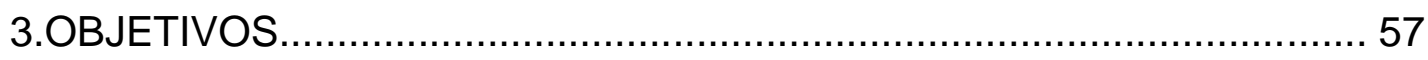

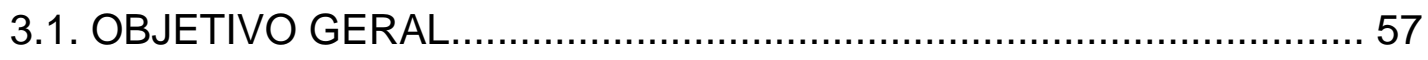

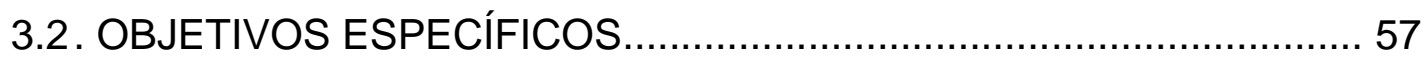

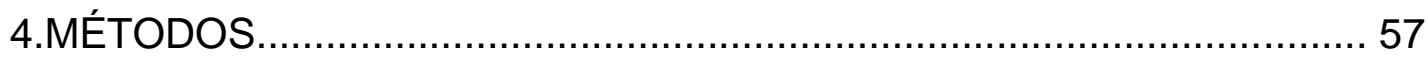

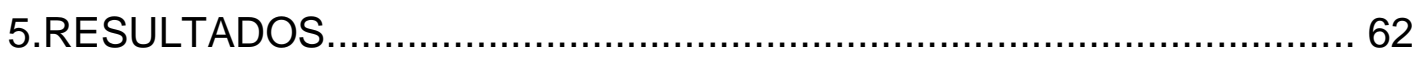

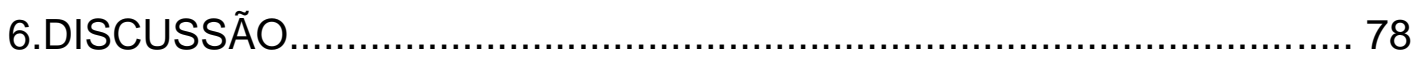

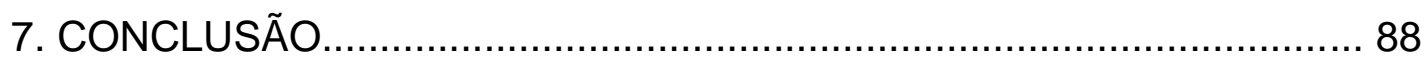

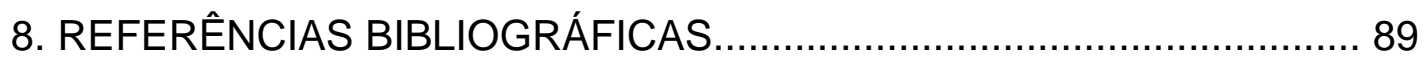

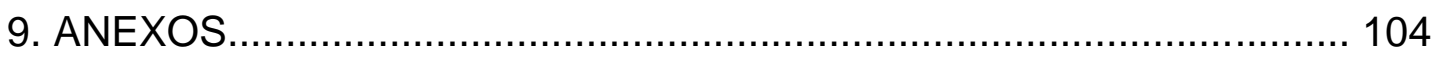




\section{RESUMO}

FRANÇA, Juliana Soares de. Características clínicas, epidemiológicas e laboratoriais da Criptococose no Distrito Federal no período de 2006 a 2013. Dissertação de Mestrado Programa de Pós-Graduação em Medicina Tropical, Universidade de Brasília, Brasília, 2015.

A criptococose, micose sistêmica causada por Cryptococcus neoformans e Cryptococcus gatti, tem emergido como importante infecção oportunista e primária. A porta de entrada no hospedeiro humano é o pulmão através da inalação de esporos ressecados da levedura presentes no ambiente. No Sistema Nervoso Central (SNC) observa-se marcado tropismo, onde desenvolve meningoencefalite grave após disseminação hematogênica. Para tentar elucidar o perfil clínico, epidemiológico e laboratorial da criptococose em pacientes atendidos na rede pública de saúde do Distrito Federal com diagnóstico laboratorial de Criptococose entre os anos de 2006 a 2013, realizou-se um estudo retrospectivo de "série de casos" a partir de registros hospitalares e laboratoriais em base eletrônica e prontuários impressos. Foram analisados 87 casos e as variáveis estudadas foram: sexo, idade, naturalidade, procedência, ocupação, unidade de atendimento, ano do diagnóstico, sintomatologia, status imunológico e achados laboratoriais de sangue e líquor, presença de comorbidades, conduta terapêutica e evolução. Observouse maior acometimento de indivíduos do sexo masculino, na faixa etária de 30 a 49 anos, sendo o HIV o principal fator de imunossupressão e a neurocriptococose como principal forma clínica. Os métodos diagnósticos foram pesquisa direta do fungo em tinta de china e cultura. A letalidade no grupo de pacientes soropositivos para o HIV mostrou-se elevada $(61,9 \%)$ quanto comparada aos indivíduos soronegativos (29,1\%). A criptococose acomete grande proporção de indivíduos imunocompetentes, além dos casos em paciente HIV positivos já esperados. Representou importante causa de infecção oportunista e morte entre os pacientes com HIV/AIDS e não AIDS configurando-se como micose de extrema relevância tornando importante compreender e caracterizar o perfil epidemiológico dos indivíduos acometidos por esse agravo.

Palavras-chaves: criptococose, Síndrome da Imunodeficiência adquirida, perfil epidemiológico. 


\begin{abstract}
The cryptococcosis, systemic mycosis caused by Cryptococcus neoformans and Cryptococcus gatti, has emerged as an important opportunistic and primary infection. The infection affects both immunocompromised as immunocompetent patients. Although the gateway in the human host is the lung by inhalation of dry spores of yeast present in the environment, the fungus has marked tropism for the central nervous system (CNS), where it causes severe case of meningoencephalitis after hematogenous dissemination. To try to elucidate the clinical, epidemiological and laboratory profile of cryptococcosis in patients treated in the public health of the Federal District with laboratory diagnosis of cryptococcosis between the years 2006-2013, there was a retrospective study of "number of cases" from hospital and laboratory records in electronic database and printed charts. We analyzed 87 cases and the variables studied were sex, age, nationality, origin, occupation, service unit, year of diagnosis, symptoms, immune status and laboratory findings of blood and cerebrospinal fluid, presence of comorbidities, therapeutics and evolution. It was observed higher prevalence of males, aged 30-49 years, HIV the main factor of immunosuppression and the neurocryptococcosis main clinical form. The diagnostic methods were direct exam of fungus paint china and culture. Mortality in the group of patients seropositive for HIV was high $(61.9 \%)$ as compared to seronegative individuals (29.1\%). The cryptococcosis affects large proportion of immunocompetent individuals, in addition to cases in HIV-positive patients have expected. It represented an important cause of opportunistic infection and death among patients with HIV /AIDS and non-AIDS configured as extremely relevant ringwormbecoming important to understand and characterize the epidemiology of individuals affected by this injury.
\end{abstract}

Keywords: Cryptococcosis, acquired immunodeficiency syndrome. Epidemiological profile. 


\section{INTRODUÇÃO}

\subsection{A Criptococose}

A importância clínica das infecções fúngicas tem aumentado drasticamente nas últimas décadas. A Criptococose é uma micose sistêmica emergente, subaguda ou crônica, ubiquamente distribuída, causada pelos fungos patogênicos Cryptococcus neoformans e Cryptococcus gatti estando associada à significativa morbidade e mortalidade (Perfectet al, 2010).Estes microrganismos podem causar infecção em indivíduos hígidos; entretanto, a maior proporção de humanos acometidos são os imunodeprimidos. (Casali et al, 2003).

Segundo Calvo et al. (2001), Lugarini (2007) e Bivanco; Machado \& Martins, (2006) o trato respiratório é a habitual porta de entrada para 0 fungo, através da inalação de propágulos infectantes. Inicialmente observase um quadro pulmonar geralmente regressivo caracterizando a fase de primoinfecção. Por disseminação hematogênica, pode atingir outros órgãos, todavia tem predileção pelo Sistema Nervoso Central (SNC) cursando clinicamente com quadro de meningoencefalite associado à elevada taxa de letalidade (Bivanco; Machado; Martins, 2006).

O estabelecimento de um quadro clínico e a disseminação da infecção tem uma estreita relação com a imunidade do hospedeiro (Larsson et al, 2003). O SNC e o trato respiratório são os órgãos que apresentam maiores repercussões clinicas na criptococose. Entretanto a doença pode manifestar-se em qualquer órgão do corpo humano, e a disseminação pode ocorrer para múltiplos órgãos em pacientes que estão gravemente imunodeprimidos (Perfect\& Casadevall, 2002).

O acometimento cutâneo secundário ocorre em $10-15 \%$ dos casos de Criptococose sistêmica e manifesta-se geralmente como conseqüência da disseminação fúngica. Clinicamente, as lesões são polimórficas, podendo manifestar-se sob a forma de pápulas, nódulos, placas, vesículas, bolhas, 
abscessos, celulite, úlceras ou púrpura, mimetizando facilmente outras entidades, como molusco contagioso, sarcoma de Kaposi ou outras infecções fúngicas sistêmicas. (Murakawa et al, 1996; Pinto Junior et al, 2003; Dharmshale et al, 2006).

$\mathrm{Na}$ Síndrome da Imunodeficiência Humana Adquirida (AIDS), a criptocococe manifesta-se majoritariamente como meningoencefalite, sendo ela a infecção oportunista neurológica de maior prevalência neste grupo de pacientes. É considerada doença definidora de AIDS já que se associa a baixas contagens de linfócitos T CD4 no soro (abaixo de 100 células) (Nadrous et al, 2003)

Globalmente, estima-se que a infecção criptocócica cause cerca de um milhão de casos de meningite por ano entre pessoas com AIDS no mundo, resultando em aproximadamente 625 mil mortes (Centros de Controle e Prevenção de Doenças, CDC, Atlanta, EUA, http://www.cdc.gov/). A maior carga de doença encontra-se na África Subsaariana e no Sudeste Asiático, onde são registrados cerca de $88 \%$ dos casos mundiais e mais de $90 \%$ das mortes por meningite criptocócica (Park et al., 2009).Segundo Kronstad et al., (2011) o número de casos fatais nestes países podem exceder as mortes por tuberculose em algumas áreas de alta endemicidade.

Nos países em que o acesso à terapia antirretroviral potente (HAART) é facilitado, como no Brasil e em países desenvolvidos, há tendência à diminuição da ocorrência de infecções oportunistas, incluindo-se a criptococose (CDC, Atlanta, EUA). Todavia, mesmo com esta queda progressiva da incidência de infecções oportunistas, estas complicações ainda constituem a principal causa de morbidade e mortalidade para a população portadora do vírus da imunodeficiência humana (HIV) em países em desenvolvimento, além de manterem elevada letalidade em todos os cenários.

No Brasil, dados epidemiológicos acerca das micoses sistêmicas são escassos uma vez que não há obrigatoriedade de notificação dos casos. Estudo realizado em 2009 por Prado e colaboradores, demonstrou um aumento anual de mortes causadas por Criptococose (de $24,5 \%$ a $26,8 \%$ ). A 
Criptococose mostrou-se prevalente nas Regiões Sul e Sudeste, com maior número de casos em homens, muito embora venha sendo observado o crescimento do número de casos em mulheres (Prado et al, 2009).

Segundo dados do Ministério da Saúde (2010), 6\% dos pacientes com AIDS, no momento do diagnóstico desta doença, tinham Criptococose. Estima-se que $5 \%$ a $13 \%$ dos pacientes com AIDS venham a desenvolver a doença. A letalidade ainda é inaceitavelmente elevada no Brasil, de $45 \%$ a $65 \%$ em casos de meningite, seja associada ou não à AIDS.

Entre os casos de criptocococe humana, o C. neoformans é o isolado mais comum em todo o mundo. Esse sorotipo totaliza mais de $95 \%$ dos casos de criptocococe oportunística. Nas regiões Sul e Sudeste do Brasil predominam a criptococose associada à AIDS, em homens, causada por $C$. neoformans, com letalidade de 35 a $40 \%$ e casos de C. gattii ocorrem esporadicamente. Nas regiões Norte e Nordeste do Brasil ocorrem em frequênciaelevada decasos de Criptococose em indivíduos sem evidências de imunossupressão, tanto no sexo masculino quanto feminino, HIV negativos, causados pela variedade gattii, comportando-se como endemia regional (Correa et al, 1999; Santos, 2000; Severo et al, 2009). Nessas regiões, a meningoencefalite criptocócica ocorre em jovens e crianças com elevada morbidade e letalidade (37 a 49\%).

\subsection{Aspectos Históricos}

A etimologia da palavra Cryptococcus, oriundo da palavra grega "Kryptos" significa "escondido", "secreto", "misterioso". Tal terminologia foi criada em 1833 por Kurtzing (Heitman et al, 2011).

A primeira descrição da Criptococose se deu em 1861 por Zenker, entretanto a validação do caso era questionável uma vez que não havia métodos para comprovar evidência da cultura do microrganismo (Heitman et al, 2011). Assim, o crédito da primeira descrição do fungo Cryptococcus neoformans foi em 1894, na Alemanha quando o patologista Otto Busse e o 
clínico Abraham Bucschke isolaram levedura capsulada a partir de um sarcoma em uma mulher de 31 anos, portadora de uma úlcera crônica em região tibial. A partir de necropsia evidenciaram-se leveduras no tecido da lesão e em múltiplos órgãos da paciente. A patogenicidade foi confirmada por meio da re-inoculação na pele da própria paciente, o que resultou em infecção disseminada e consequente morte. As leveduras isoladas foram então nomeadas por Busse e Abraham de Saccharomyces hominis e a infecção Saccharomycosis hominis (Knoke; Schwesinger, 1994).

No mesmo ano, na Itália, Francesco Sanfelice isolou a partir de suco de pêssego, uma levedura encapsulada e no ano seguinte demonstrou sua patogenicidadeem animais de laboratório, denominando-a Saccharomycesneoformans devido a sua tendência de causar lesões semelhantes a tumores cancerígenos (Khan et al, 2010; Littman\& Zimmerman, 1956 apud Casadevall \& Perfect,2003).

Em 1885, um ano após a descrição da Criptococose por Busse e Buschke, Ferdinand Curtis, na França, descreveu uma levedura em uma lesão de quadril de um homem jovem e relatou o segundo caso de Criptococose, denominando-a segundo suas observações morfológicas de Saccharomyces subcutaneous tumefaciens considerando ser distinta das leveduras descritas por Sanfelice e Busse.

Devido à incapacidade de formação de ascósporos e de fermentação por fontes de carbono, características das espécies do gênero Saccharomyces em 1901, Vuillemin reclassificou os isolados de Busse, Bushcke e Sanfelice colocando-os no gênero Cryptococcuse as espécies $C$. hominis e C. neoformans (KHAN ET AL., 2010).

A primeira metade do século $X X$ marcou a consolidação de Criptococcus neoformans como levedura patogênica. Em 1902, Fronthingham reconheceu a patogenicidade da levedura através de lesão pulmonar em um cavalo que era similar aos fungos isolados por Busse e Buschke. Com seus achados comprovou-se que o fungo era patogênico tanto para humanos quanto animais. Em 1905, Cryptococcus neoformans foi descrito como agente causador de meningoenceflite por Von Hansemann. 
No caso referido, foram descritas lesões císticas, de aspecto gelatinoso, com visualização de leveduras em abundância.

A meningite por Cryptococcus foi descrita por Verse em 1914 em mulher antes da sua morte. Dois anos depois, outros dois casos de meningoencefalite foram descritos por Stoddard e Cutler que denominaram o fungo de Torula histolytica e a doença de torulose. Anos mais tarde, entre 1917 e 1927, foram publicados estudos mostrando o uso de tinta de nanquim para visualização da cápsula em suspensões de cultivos (Lazéra; Igreja; Wanke, 2004; Perfect, 2010).

Em 1935, Benham estudando inúmeros isolados recuperados de humanos, sendo 22 cepas patogênicas, que haviam sido identificadas como pertencentes aos gêneros Saccharomyces, Cryptococcus e Torula e analisando possíveis semelhanças e diferenças quanto à morfologia, patogenicidade e reatividade a fatores séricos, concluiu que pertenciam a um só gênero e espécie, agrupando-os dentro do gênero Cryptococcus.Em 1950, a própria pesquisadora propôs que o nome torulosi e torula meningite fosse renomeada para Criptococose e que o nome Cryptococcus neoformans fosse conservadodevido a forma imperfeita da levedura, tornando-se definitiva e utilizadanos dias atuais(Heitman et al,2011).

Ao final da década de 1940 iniciaram-se os estudos de sorotipagem baseados em reação imunológica com antissoro produzido contra diferentes epítopos do polissacarídeo capsular que permitiram descrever padrões diferentes de aglutinação a anticorpos presentes em soros hiperimunes de coelhos. Em 1949, Evans descreveu diferenças sorológicas entre as cepas isoladas a partir de pacientes com Criptococose. Os sorotipos A, B, C e o sorotipo D foi descrito posteriormente. Em 1950, Emmons publicou estudo mostrando a relação de $C$. neoformans com matéria orgânica rica em excretas de pombos e solos contaminados. Staib, em 1962, ao realizar estudos em meio de cultura com presença de sementes de Níger (Guizotia abyssinica) percebeu a coloração negra de $C$. neoformans pela produção de melanina, desde então o extrato dessa semente, associado a antibióticos e Agar passaram a ser utilizados como método seletivo para isolamento da 
levedura, colaborando com estudos ambientais (Emmons, 1951; Làzera; Igreja; Wanke, 2004).

Em 1970, Gattii e Eeckels isolaram cepas de C. neoformans de uma criança que sofria de meningoencefalite no Zaire. No mesmo ano, Vanbreuseghem e Takashio descreveram que o isolado produzia células alongadas "in vivo" e na cultura assemelhava a um típico isolado de $C$. neoformans, assim descreveu-se uma nova variedade e foi nomeado $C$. neoformans var.gatti. Em 1975, Kwon- Chung et al (1975) reproduziram a forma sexuada do fungo in vitro e determinaram que $C$. neoformans var neoformans e $C$. neoformans var.gattii, diferiam consideravelmente nas características morfológicas, bioquímicas e sorológicas e que o isolado do Zaire era idêntico a uma cepa teleomórfica de Filobasidiella bacillisporareclassificando o fungo como pertencente $C$. bacillisporus (Kwon-Chung et al, 1975; Popkin, 1976). Em 2002, o nome C. bacillisporus foi renomeado para C.gattii, pois o termo "gattii" era mais amplamente usado pelo mundo (Heitman et al.,2011).

Desde os primeiros isolados de Cryptococcus sua taxonomia vem passando por novas revisões. Através de embasamentos genéticos houve mudança taxonômica das variedades para a categoria de espécie: $C$. neoformans e C. gatti (Kwon- Chung,2002; Lazéra; Igreja; Wanke, 2004).

Em 2005, um estudo multicêntrico descreveu todas as características a respeito do projeto genoma para $C$. neoformans. O sequenciamento genômico foi realizado inicialmente a partir de duas cepas de sorotipo $D$ ( $C$. neoformans). $O$ projeto genoma possibilitou o alcance de novas ideias e posterior avanço em pesquisa, facilitou o estudo da doença e seus agentes etiológicos bem como a patogênese da espécie fúngica (Hughes et al, 2008). 


\subsection{Classificação Taxonômica}

Para Kurtzman, Fell e Boekhout (2011) a classificação taxonômica do complexo Cryptococcus neoformans e Cryptococcus gattii distingue-se no seu estado teleomórfico e anamorfos, sendo:

Estado teleomórfo:

a) Reino Fungi

b) Filo Basidiomycota;

c) Ordem Tremellales;

d) Família Tremellaceae;

e) Gênero Filobasidiella

Espécie:

a) Filobasidiella neoformans variedade neoformans (sorotipo $A$ e D)

b) Filobasidiella neoformans variedade bacillispora (sorotipo $B$ e $C$ )

No estado anamorfo os correspondentes são:

a) Cryptococcus neoformans (sorotipos A e D)

b) Cryptococcus gatti (sorotipos B e C).

\subsection{Micologia}

O gênero Cryptococcus é conhecido há mais de 100 anos e atualmente existem 68 espécies com ampla distribuição em uma variedade de ambientes como solo, árvores e animais, principalmente aves (Kurtzman; Fell; Boekhout, 2011; Heitmanet al, 2011; Bocca\&Casadevall,2013).

Cryptococcus neofrormans e C. gatti são consideradas leveduras não fermentadoras, assimiladoras de inositol, produtoras de urease e reativas ao azul de diazônico B. São geralmente haplóides, globosas ou ovaladas, com diâmetro variando entre 3-8 $\mu \mathrm{m}$. Frequentemente expressam cápsula volumosa in vitro e reproduzem-se por brotamento único ou múltiplo, 
configurando a forma assexuada de reprodução (Lazéra; Igreja; Wanke,2004). Atualmente cryptococcus neoformans e cryptococcus gatti são as únicas espécies primariamente patogênicas, no entanto, recentemente outras espécies como $C$. albidus, $C$. laurentii e $C$. curvatus, têm sido descritas na literatura como causa de infecção em humanos (Pfaller; Mcgginnis \& Anaissie, 2009).

Embora no passado o agente etiológico da criptococose tenha sido considerado uma espécie anamórfica homogênea (C.neoformans), atualmente as duas espécies, Cryptococcus neoformans (sorotipos A, D, e híbrido AD) e Cryptococcus gattii (serótipos B e C), foram separadas considerando que diferem genotipicamente, fenotipicamente, em epidemiologia, bem como na sua distribuição geográfica e ecologia (Perfect \& Casadevall 2002, Kwon Chung \& Varma 2006; Lazéra; Igreja; Wanke, 2004; Perfect, 2010).

Estudos filogenéticos, empregando tipagem molecular permitiram a divisão das duas espécies em oito tipos moleculares: $C$. neoformans var.grubii em VNI, VNII e VNB; VNIII a um tipo híbrido sorotipo AD e VNIV a $C$. neoformans var. neoformans (sorotipo D). Os tipos moleculares VGI, VGII, VGIII e VGIV correspondem a C. gattii. O genótipo VGIl foi subdividido em VGlla, VGllb por Kidd et al. (2004).

Os tipos moleculares $\mathrm{VNI}$ e VNII de $C$. neoformans possuem ocorrência global respondendo por $95 \%$ das infecções criptocóccicas em todo o mundo e $98 \%$ em pacientes com HIV/ AIDS. O tipo molecular VNB é geograficamente descrito em isolados na África do Sul.

O genótipo VGlla foi isolado predominantemente em pacientes e fontes ambientais durante o surto na llha de Vancouver em 1999 e na Costa Oeste do Pacífico, reafirmando a presença desse patógeno para além das regiões tropicais e subtropicais, para em regiões temperadas (Kidd et al. 2004). Em 2004 registrou-se ocorrência de infecção humana em Oregon e Washington, EUA (Byrnes et al, 2010). 
Enquanto o $C$. neoformans tem caráter oportunista acometendo predominantemente, pacientes com AIDS ou imunodeprimidos por outras causas (Mitchell \& Perfect.,1995), C. gattii age como patógeno primário causando doença em indivíduos imunocompetentes (Rozembaum et al 1990 ; Mitchell \& Perfect.,1995; Corrêa et al 1999).

O surto na llha de Vancouver acometeu 38 pessoas, sendo a maioria delas imunocompetentes, resultando em lesões pulmonares, associadas à meningite, com letalidade de $10 \%$. Identificou-se ainda a micose em animais domésticos e silvestres (Kiddet al, 2004; Costa, 2009).

\subsection{Epidemiologia e Distribuição Geográfica}

Atualmente na literatura Criptococcus é descrito como cosmopolita com ocorrência em diversos nichos ecológicos, solo, tecidos, secreções e excreções dos animais e do próprio homem. Está bem estabelecido que as excretas de pombos e outras aves são meios de cultura férteis para o crescimento do fungo e as fezes velhas são ricas em bases nitrogenadas (uréia e creatinina) nutrientes importantes para o fungo. $O$ desenvolvimento em excretas de aves provavelmente se deve à adaptação bioquímica, que consiste na habilidade de assimilar creatinina, bem como ácido úrico e purinas como fontes de nitrogênio, compostos estes encontrados em abundância nesse nicho ecológico (Morettiet al, 2008).

No entanto, as aves dificilmente se infectam com Cryptococcus, uma vez que apresentam temperatura interna de $42^{\circ} \mathrm{C}$ responsável pela inibição da multiplicação fúngica (KWON et al., 2006). Contudo, podem ser vetores potenciais para a disseminação do fungo. Os estudos de Swinne-Desgain (1976) demonstraram que muitos pombos transportama levedura e que estas podem permanecer viáveis por até 86 dias no intestino, o que sugere 0 importante papel destas aves na disseminação ambiental de $C$. neoformans.

Além dos nichos descritos, recentes trabalhos descrevem 0 isolamento deste fungo em igrejas, sótãos, janelas de prédios antigos, 
praças, estábulos, celeiros e barracões. Praças e parques são considerados potenciais nichos para Cryptococcus spp por serem locais onde concentramse restos alimentares e lixo que servem de alimentos para as aves associadas. $\mathrm{O}$ ambiente domiciliar, particularmente a poeira doméstica, pode apresentar positividade (50\% e 13\%) (Baroniet al, 2006).

Passoni et al (1998) coletaram 824 amostras ambientais em 154 residências da cidade do Rio de Janeiro (poeira domiciliar, solo de área externa domiciliar, excretas de pássaros). Isolaram C. neoformans em 15,6\% das 32 residências de pacientes com Criptococose associada a AIDS, em $8,9 \%$ das 45 residências de pacientes com AIDS mas sem Criptococose e em $14,3 \%$ das 77 residências de indivíduos saudáveis ( $p>0,05$ ). $O$ isolamento de C. neoformans em $13 \%$ das 154 residências reforça a observação da exposição frequente do ser humano ao fungo. Posteriormente, em 2006, Baroni et al (2006) isoloramCryptococcus neoformans de fezes de pombo em torres de igreja no Rio de Janeiro. Ainda neste ano, com objetivo de isolar o fungo a partir de excretas de aves comercializadas em "Pet Shop", após análise de 1268 amostras, verificou $6.7 \%$ de positividade.

Para Casadevall \& Perfect (1998) C. neoformans tem distribuição global com grande capacidade de adaptação, sobrevivendo ao frio congelante da Antártida, a elevadas altitudes do Himalaia e a salinidade dos mares. Os mesmos autores acrescentam que apesar da ampla distribuição do Cryptococcus no ambiente, a Criptococose é uma infecção de ocorrência esporádica, demonstrando desproporção entre o número de pessoas expostas e as que adoecem (Casadevall\& Perfect, 1998).

Os isolados ambientais iniciais de $C$. gattii em diversos continentes indicam principalmente as árvores de eucaliptos como principal fonte de desta variedade (Ellis; Pfeiffer,1990; Chakrabartet al, 1997; Pfeiffer; Ellis,1992; Halliday\&Carter, 2003; Vilcins et al, 2002; Casali et al, 2003; Granados\& Castaneda,2006; Montenegro; Paula,2000; Refojo et al, 2009; Pfeiffer; Ellis,1991; Chakrabart et al, 1997). Contudo, alguns estudos recentemente publicados com amostras ambientais têm sugerido a presença 
cosmopolita de $C$. gattii ocupando nichos ecológicos similares ao do $C$. neoformans, associando-o a madeira deteriorada, restos de vegetais e solo(Cogliati, 2013).

Estudo que se baseou numa análise detalhada da distribuição geográfica dos principais tipos moleculares das duas espécies de Cryptococcus apontou que na América do Sul e Central entre as 10.548 estirpes de Cryptococcus isoladas 53\% foram descritas no Brasil, $22 \%$ da Colômbia, $15 \%$ da Argentina, e uma menor percentagem de em outros países. Um total de $8.590(81 \%)$ estirpes foram isoladas a partir de fontes clínicas e 1958 (19\%) a partir do ambiente e animais.

Foram detectados isolados naturais de $C$. neoformans a partir de excretas de pombos e outras aves, solo, poeira e habitações contaminadas, assim como em espécies de eucalipto, árvore de amêndoa,entre outros. Alguns isolados também foram recuperadosa partir de excretas de insetos, touroe ovelhas. C. gattii foi isolado a partir do solo, poeira, e excrementos de aves e em madeira em decomposição(Cogliati, 2013).

No Brasil a maioria dos isolados pertencia ao tipo molecular VNI seguido por VGIl e os tipos VNII,VNIV, VGI e VGIII ocorreramem um menor proporção e em semelhante proporção.

Estudos anteriores mostraram heterogeneidade na distribuição geográfica de C. neoformans e C. gattii no Brasil, (Correa et al 1999, Nishikawa et al 2003, Pappalardo \& Melhem, 2003). Nishikawa et al (2003), em análise de 467 amostras, referem isolamento de $C$. neoformans e $C$. gattii de material clínico, respectivamente, de $89 \%$ e $7,5 \%$ no sul/sudeste e de, respectivamente, $34,3 \%$ e $62,7 \%$ no nordeste; do meio ambiente (excretas de pássaros, madeira em decomposição, poeira doméstica), C. neoformans foi isolado em $90,2 \%$ das amostras no sul/sudeste e $34,5 \%$ no nordeste e $C$. gattii em $1,96 \%$ no sul/sudeste e $62 \%$ no nordeste.A primeira descrição de casono Brasil ocorreu em 1999 em Belém do Pará, com registro de 19 casos sendo que em nove foi registrada a ocorrência de C.gattii. A média de idade dos pacientes foi de 7,8 anos e todos os casos resultaram em comprometimento do SNC. Montenegro \& Paula (2000) 
verificaram que nas áreas urbanas da cidade de São Paulo o C.neoformans e o $C$. Gatti estão presentes. O C. gattii foi isolado a partir de material derivado de eucaliptos e o $C$. neoformans foi isolado em fezes de pombos.

Em 2005, Soares et al (2005) analisaram 79 amostras de fezes de pombos e 37 de ar atmosférico, próximo dos excrementos das aves na cidade de Santos, sendo que dessas amostras uma ampla variedade de espécies de Cryptococcus foram encontradas e dentre elas $13,9 \%$ de $C$. neoformans var grubbi.

C. gattii é considerado endêmico no Nordeste do Brasil, tem sido isolado em ocos de árvores de diferentes espécies, como mangueira (Manguira indica), gameleira (Ficus spp.), cássia gigante (Cassia grandis) e também eucalipto (E. camaldulensis) (Lazéra; Igreja; Wanke,2004). Lazéra et al (2000) de 1995 a 1998, isolaram o C.gattii de ocos de árvores das cidades de Teresina e Rio de Janeiro, na opinião da pesquisadora, os ocos de árvores representam, ainda, interessante correlação potencial com aves, pois os utilizam para fazerem ninhos dentro dessas cavidades, roendo madeira. Tais biótopos permitem interações entre fungo e protozoários, insetos, pequenos roedores e morcegos de ambientes urbanos e silvestres.

Com base em estudos brasileiros Cryptococcus spé a sexta causa de infecção oportunista em pacientes com AIDS, após Candida sp, Mycobacterium sp, $P$. carinii, Toxoplasma gondii e o vírus da herpes simples (Guimarães 2000, Menezes et al 2002; Batista et al, 2005).

\subsection{Imunopatogênese}

A levedura $C$. neoformans é um patógeno intracelular capaz de interagir com o sistema imune do hospedeiro humano para estabelecer a doença. A infecção inicia-se quando o hospedeiro suscetível entra em contato com as leveduras desidratadas presentes no meio ambiente através da inalação de propágulos infecciosos conforme ilustra a figura 1. Por possuírem tamanho muito pequeno (cerca de $3 \mu \mathrm{m}$ ) as partículas infecciosas 
conseguem depositar-se em regiões profundas do trato respiratório humano (Lazéra; Igreja; Wanke, 2004; Velagapudi et al, 2009; Sabiiti \&May,2012).

A patogênese da Criptococose é determinada por três fatores principais: o status imunológico do hospedeiro, a virulência da cepa e o tamanho do inoculo. A relativa importância de cada fator como determinante de doença clínica permanece incerta, entretanto assegura-se que a complexidade dessas interações decide a apresentação final (PERFECT, 2010).

Figura 1: Ciclo de infecção por Cryptococcus spp.

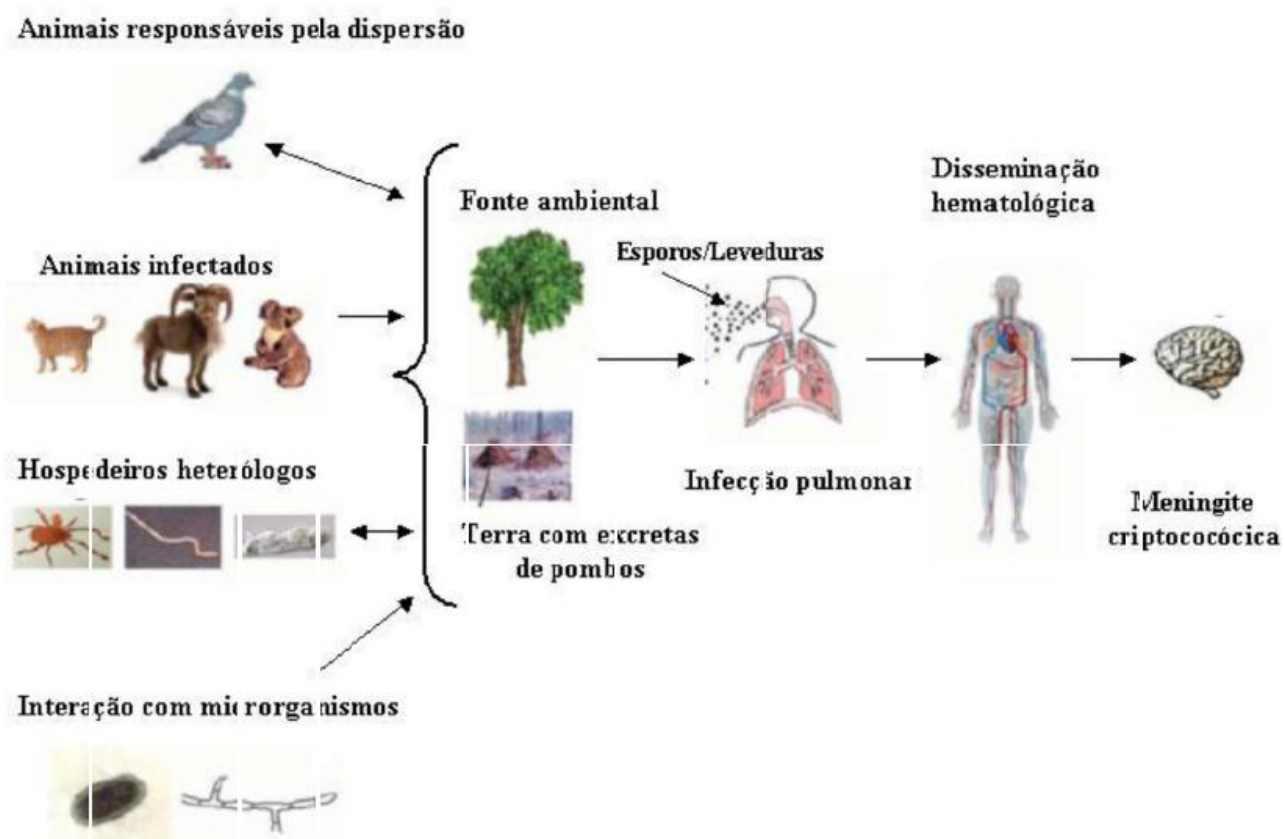

A levedura pode ser encontrada no solo ou associada a excretas de pombos e troncos de árvores, podendo infectar hospedeiros de várias espécies distintas, como gatos, cabras e coalas. As células fúngicas podem sobreviver em associação com hospedeiros ambientais como amebas, carrapatos e vermes. Os pombos são considerados a principal forma de dispersão do fungo, e acredita-se que a principal forma de infecção ocorre por inalação de esporos ou leveduras dessecadas, que podem estabelecer infecção primária no pulmão e posteriormente sofrer disseminação hematogênica, causando meningite criptocócica. Adaptado de Lin e Heitman, 2006 (Lin e Heitman,2006). 
Nos alvéolos, o contato das leveduras com os macrófagos locaise células dendríticasdeterminam a fagocitose com o recrutamento de outras células inflamatórias através de citocinasou quimiocinas, consistindo o primeiro passo para que uma resposta Th1 seja deflagrada. A partir de então, uma de três vias pode ocorrer: 1)em indivíduos imunossuprimidos ocorre proliferação e disseminação da levedura causando a doença pulmonar caracterizada por nódulos pulmonares e/ou inflamação e doença disseminada com maior frequência no cérebro; 2) não desenvolvimento da doença com eliminação completa do fungo diante de uma resposta imune eficaz ou; 3) infecção assintomática quando o fungo entra em estado de latência em linfonodos pulmonares. $O$ fungo permanece dormente e 0 hospedeiro sem sintomatologia até que um quadro de imunossupressão leve a reativação, replicação e posterior disseminação para outros órgãos (Perfect, 2010; Kronstad e al,2011; Sabiiti\& May,2012). Esta fisiopatologia é semelhante ao cenário proposto para a reativação da tuberculose e histoplasmose (Garcia-Hermoso; Janbon; Dromer, 1999).

Os macrófagos alveolares compõem cerca de $95 \%$ das células no lavado bronco alveolar e são os fagócitos de primeira linha de defesa contra patógeno (Gordon\& Read,2002). Frequentemente, este processo resulta na formação de "criptococomas",ouseja, granulomas contendo células fúngicas que são essenciais para a contenção da disseminação extrapulmonar.

Estes granulomas resultam de uma resposta polarizada para células T- helper 1 (Th1), as citocinas como fator de necrose tumoral, interferon- y e interleucina-2 fazem-se necessários, resultando em granuloma benigno composto por fagócitos mononucleares maduros, histiócitos e células multinucleadas gigantes envolvidas pelas células (Coelho, Bocca; Casadevall,2013). Os mesmos autores acrescentam que os macrófagos são importantes tanto para o controle quanto para a persistência da infecção o que foi demonstrado que a depleção dos macrófagos diminui a disseminação da levedura para o cérebro de ratos uma vez que para transporte do fungo há a internalização em macrófagos. 
Para que ocorra a disseminação das células fúngicas são descritos três possíveis mecanismos pelos quais o fungo pode atravessar a barreira hematoencefálica e penetrar no (SNC) resultando na meningoencefalite, manifestação mais importante e comum (figuras 2 e 3). $O$ primeiro mecanismo conhecido como "Cavalo de Tróia" a levedura é engolfada por células fagocíticas e no interior dos fagócitos o fungo trafega na BHE sem exposição ao sistema imune (Luberto et al, 2003; Kronstad et al, 2011).

Figura 2: Modelo de disseminação de $C$. neoformans.

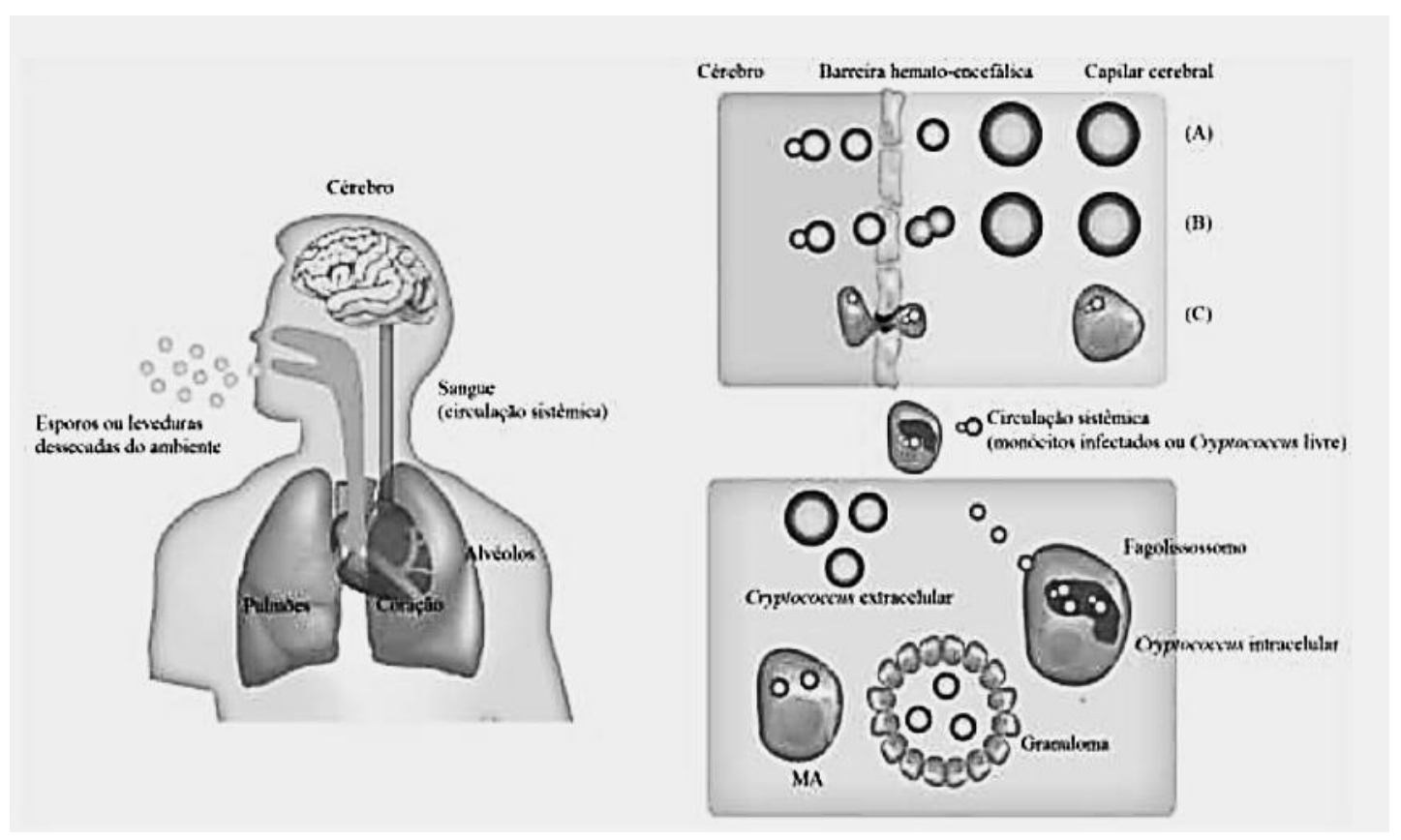

Através da inalação, esporos ou leveduras dessecadas colonizam o espaço alveolar nos pulmões. Em indivíduos imunocompetentes, macrófagos alveolares ativados (MA) fagocitam e matam ou envolvem as células de Cryptococcus em granulomas. No interior de granulomas as células de Cryptococcus podem ficar em estágio de latência ou serem reativadas para causar infecção, dependendo do estado imune do indivíduo. O fungo Cryptococcus, pode a disseminar-se na circulação sistêmica e penetrar a barreira hemato- encefálica (BHE) através do $(A)$ mecanismo paracelular, onde as células fúngicas causam danos às células epiteliais, (B) por transcitose, onde as células fúngicas ligam-se ou são internalizadaspor células endoteliais do cérebro ou (C) pelo mecanismo conhecido como "Cavalo de Tróia”, onde as células fúngicas atravessam a BHE no interior de macrófagos ou monócitos. Figura adaptada de Sabiiti e May, 2012 (Sabiiti \& May, 2012). 
Já é bem estabelecida a sobrevivência e proliferação de células fúngicas nos macrófagos alveolares, resistindo ainda ao estresse oxidativo e ao ambiente adverso no interior do fagossomos. As leveduras podem escapar de macrófagos por exocitose não lítica sem causar danos tanto para as células fúngicas quanto para a célula fagocítica do hospedeiro ( $M a$ \& May, 2009). O segundo processo sugere que pode ocorrer uma transferência lateral, mecanismo de "transcitose", em queos fagócitos infectados internalizam a levedura para ascélulas endoteliais microvasculares que revestem os vasos sanguíneos do cérebro gerando mudanças no citoesqueleto que auxiliam a entrada da levedura no cérebro (Ma \& May, 2009; Kronstad et al, 2011).

No terceiro mecanismo, no modelo paracelular as células fúngicas são capazes de ultrapassar sozinhas as células endoteliais e assim atingir o tecido cerebral (Ma \& May, 2009; Sabiiti e May,2012)

Figura 3: Possíveis rotas utilizadas por $C$. neoformans para ultrapassar a barreira hematoencefálica.

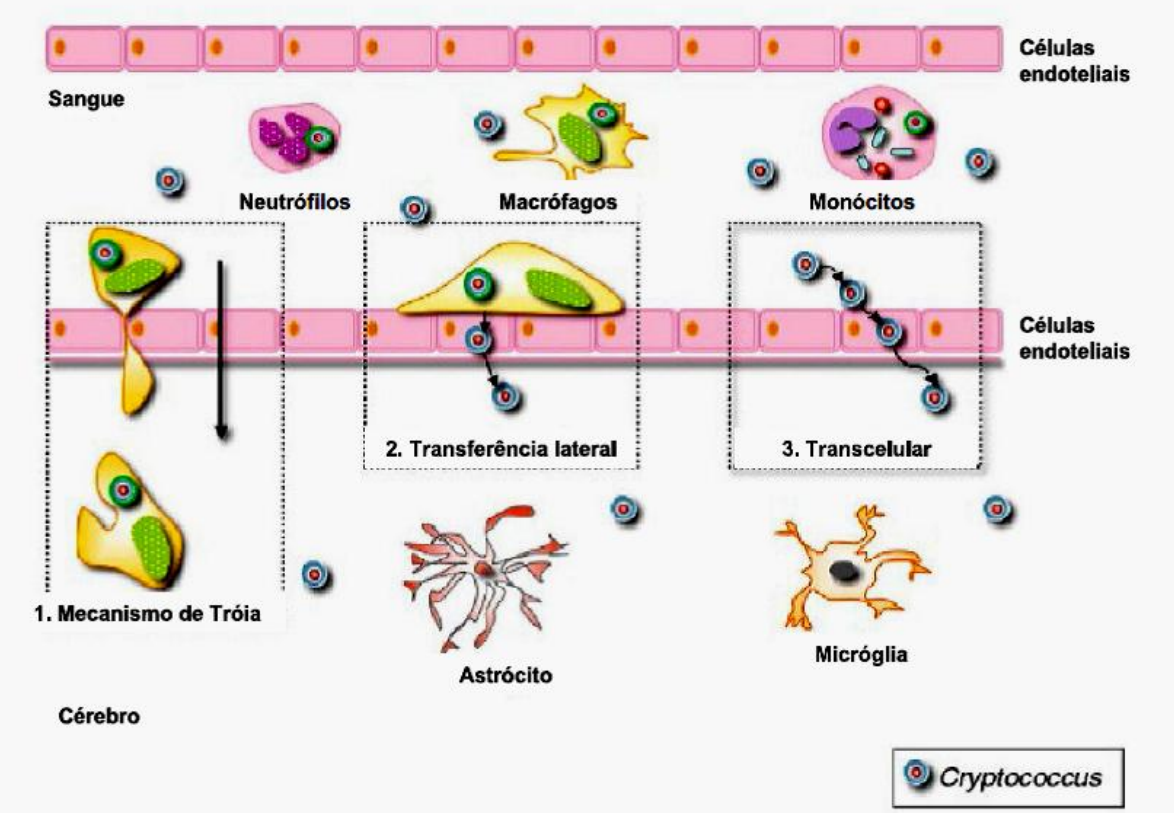

(1) mecanismo de "cavalo de Tróia"; (2) transferência lateral de macrófagos para células endoteliais; e (3) travessia de leveduras isoladas por uma via transcelular. Adaptado de Ma \& May, 2009. 
A imunidade celular é uma importante defesa do hospedeiro contra C. neoformans e C. gattii, sendo crucial para conter a Criptococose. Não é só o estado de ativação celular ou o tipo de célula do hospedeiro, mas também o quantitativo de células no sítio da infecção quesão responsáveis por uma resposta imune eficaz. Os estudos em pacientes HIV/AIDS evidenciam que o risco da infecção aumenta drasticamente quando há grande depleção de linfócitos T CD4 (helper) abaixo de 50 a 100 células por microlitro de sangue (Pongsai; Atamasirikul; Sungkanuparph,2010). A Criptococose em pacientes com AIDS ocupa a terceira ou quarta infecção oportunista no mundo e no Brasil estima-se que $5 \%$ a $13 \%$ dos pacientes com AIDS venham a desenvolver a doença.

O caráter oportunista da doença resulta do comprometimento da imunidade celular abrangendo assim pacientes com quadros de importante imunodepressão como linfomas, leucemias crônicas, diabetes, lúpus eritematoso sistêmico, sarcoidose, AIDS, uso de corticóides e transplante de órgãos.

\subsection{Determinantes de/ ou Fatores relacionados à virulência}

Para garantir sobrevivência e replicação o $C$. neoformans e $C$. gattii possuem diversas estratégias para evadir dos mecanismos de destruição de microrganismos intra e extracelulares e desenvolveram a capacidade de modular a resposta imune contra elespor meio daexpressão defatores de virulência que permitem invasão tecidual, fontes nutricionais e mecanismos de escape e agressão às defesas do hospedeiro contribuindo para sua patogenicidade (Sabiiti \& May,2012).

A liberação destes fatores de virulência fúngicos para 0 ambiente extracelular ocorre a partir de vesículas ligadas à membrana que atravessam 
a parede celular. Rodrigues et al, em 2008 demonstraram que o $C$. neoformans é capaz de secretar vesículas contendo muitos de seus fatores de virulência, incluindo glucuronoxilomanana-GXM, lacase, uréase e fosfolipase B podendo estimular macrófagos. A tabela 1 destaca os principais fatores realcionados à virulência do Cryptococcus.

Tabela 1: Fatores Relacionados à Virulência do Cryptococcus neoformans

Fator de Virulência

\begin{tabular}{|c|c|}
\hline $\begin{array}{l}\text { Cápsula e polissacarídeos } \\
\text { associados }\end{array}$ & $\begin{array}{ll}\text { - } & \text { Evasão da fagocitose } \\
\text { - } & \text { Redução da apresentação de antígeno } \\
\text { - } & \text { Redução da produção de citocinas } \\
\text { - Indução de células T supressoras que inibem a } \\
\text { imunidade mediada porcélulas } \\
\text { - } \quad \text { Inibição da resposta das células T pela GXM } \\
\text { - } \text { de ibição pela GXM da migração de leucócitos a sítios } \\
\text { de }\end{array}$ \\
\hline Melanina & $\begin{array}{l}\text { - } \quad \begin{array}{l}\text { Tolerância ao calor e frio } \\
\text { - }\end{array} \text { Proteção contra radiação UV e radicais livres derivados } \\
\text { de oxigênio e nitrogênio } \\
\text { - } \quad \text { Contribuição com o tropismo pelo SNC } \\
\text { - } \quad \text { Contribuição para carga célula negativa }\end{array}$ \\
\hline Proteases extracelulares & $\begin{array}{l}\text { - } \quad \text { Atividade proteolítica } \\
\text { Degradação de proteínas envolvidas na integridade } \\
\text { tecidual e imunidade do hospedeiro; } \\
\text { - Dano tecidual }\end{array}$ \\
\hline Fosfolipases & $\begin{array}{l}\text { - Invasão tecidual pela degradação de lipídeos de } \\
\text { membrana de mamíferos e surfactante pulmonar }\end{array}$ \\
\hline Ureases & $\begin{array}{l}\text { - } \quad \text { Captação de nitrogênio } \\
\text { - } \quad \text { Transferência do Cryptococcus para SNC }\end{array}$ \\
\hline Mating Type & $\begin{array}{ll}\text { - } & \text { Reprodução sexuada } \\
\text { - } & \text { Regulação dos fatores de virulência } \\
\text { - } & \text { Aumento da síntese de difenoloxidase (tipo de lacase) }\end{array}$ \\
\hline Crescimento a temperatura de $37^{\circ} \mathrm{C}$ & Sobrevivência e persistência no hospedeiro \\
\hline Tolerância a pH baixo & Sobrevivência e persistência no ambiente \\
\hline Tolerância a níveis elevados de sal & Sobrevivência e persistência no ambiente \\
\hline Mudança Fenotípica & $\begin{array}{l}\text { - Mudança no tamanho da cápsula-variante mais } \\
\text { virulenta e capaz de ultrapassar a barreira } \\
\text { hematoencefálica }\end{array}$ \\
\hline
\end{tabular}

Fonte: Casadevall et al., 2003; Ashwin et al., 2000 


\subsubsection{Cápsula Polissacarídea}

Cápsulas são em geral de extrema importância para a sobrevivência de alguns microorganismos, fornecendo resistência a condições de estresse tal como desidratação e desenvolvendo papel chave na interação com o ambiente. Nas últimas décadas a cápsula do $C$. neoformans vem sendo extensivamente estudada. Os principais aspectos dizem respeito a sua estrutura, as propriedades antigênicas e sua função como um fator de virulência. A cápsula corresponde uma estrutura extracelular composta por dois polissacarídeos complexos, a glucoronoxilomanana (GXM) que representa $92 \%$ da massa polissacarídea; e a galactoxilomanana (GalXM) e uma pequena proporção de uma mananoproteinas (MP) proteínas ligadas a glicanas ricas em resíduos de manose (figura 4) (De Jesus et al, 2010; Zaragoza et al, 2009).

Figura 4: Cápsula polissacarídica

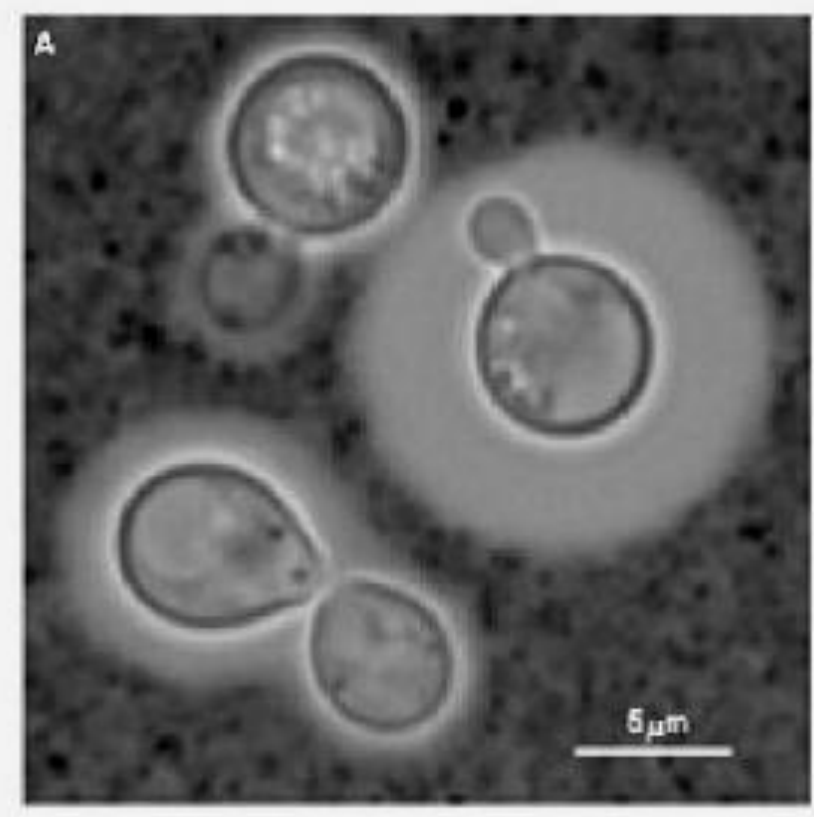

Coloração com tinta da china revela a cápsula que circunda as células leveduriformes de $C$. neoformans. Adaptado de Ma \& May, 2009. 
A especificidade antigênica dos sorotipos em $A, B, C, D$ e $A D$ é determinada pelo principal polissacárideo capsular, a GXM sendo baseado pelas diferenças estruturais no número de resíduos de xilose e o grau de Oacetilação de grupos hidroxilas da GXM. A produção da cápsula é o maior fator de virulência de $C$. neoformans e $C$. gattii, uma vez que confere ao fungo propriedades anti-fagocíticas, além de envolver-se na modulação da resposta imune (Lazéra; Igreja;Wanke, 2004; Zaragoza et al, 2009).

Estudos apontam que infecções causadas por cepas acapsulares ou pobremente capsuladas são menos virulentas; ou ainda linhagens altamente encapsuladas são menos fagocitadas por macrófagos, o que diminui a proliferação de células $\mathrm{T}$ e apresentação de antígenos pelos macrófagos, assim como também reduz a disseminação sistêmica (Alspaugh; Perfect; Heitman, 1998; Zaragozaet al, 2009).

A síntese da cápsula polissacarídea envolve dezenas de genes como - CAP10, CAP59, CAP60 E CAP64 considerados essenciais para a biossíntese de GXM. Os mecanismos reguladores do tamanho e da estrutura capsular ainda precisam ser melhores identificados, masacreditase na influência do soro sanguíneo, limitações de ferro, níveis de $\mathrm{CO} 2$ e contato com macrófagos(Bose et al, 2003; Janbon,2004).

Para Lupo e colaboradores (2008) a cápsula inibe a maturação das células dendríticas e a expressão de receptores de superfície e citocinas como IL2, IL12, IL $\alpha$, IL $\beta$, IL6, IL10, TNF $\alpha$, proteínas de membrana, genes envolvidos no processamento e apresentação de antígenos, bem como no ciclo celular e apoptose.

Alguns pesquisadores têm evidenciado que a expressão capsular protege o fungo de estresse oxidativo quando internalizado na célula hospedeira. O componente capsular age como barreira antifagocítica, depleta complemento, produz irresponsividade de anticorpos, promove desregulação na secreção de citocinas e na apresentação de antígenos, permitindo carga altamente negativa ao redor da levedura (Zaragoza \&Casadevall,2004; Zaragozaet al, 2008). 
Entretanto estudos recentes têm demonstrado que independentemente da cápsula o fungo possui estratégias antifagocíticas como a expressão de proteínas como App1, que inibe a fagocitose através da ligação aos receptores CR2 e CR3, e do fator de transcrição GAT201, com deleção que gera fungo hipocapsulado que é mais susceptível à fagocitose (Chun, Brown \&Madhani,2011)

\subsubsection{Produção de Melanina}

A produção de melanina é o segundo fator de virulência mais estudado e observado em muitos fungos, incluindo algumas espécies patogênicas para o ser humano. São macromoléculas de coloração preta ou marrom, hidrofóbicas, de alto peso molecular, sintetizadas pela polimerização oxidativa de compostos fenólicos e/ou indólicos.C. neoformans tem a capacidade de sintetizar melanina partir da ação da enzima lacase que catalisa a conversão decompostos exógenos difenólicos como L-DOPA, dopamina, norepinefrina e epinefrina no pigmento (Figura 5), vinculada à parte interna da membrana plasmática (Casadevall et al., 2003; Karkowska-Kuleta et al, 2009)

A produção de melanina por $C$. neoformans foi primeiramente descrita em 1962. Staib relatou colônias de Cryptococcus com coloração marrom em Agar contendo extrato de semente de Guizotia abyssinica (Heitmanet al, 2011). 
Figura 5. Produção de melanina por Cryptococcus neoformans.

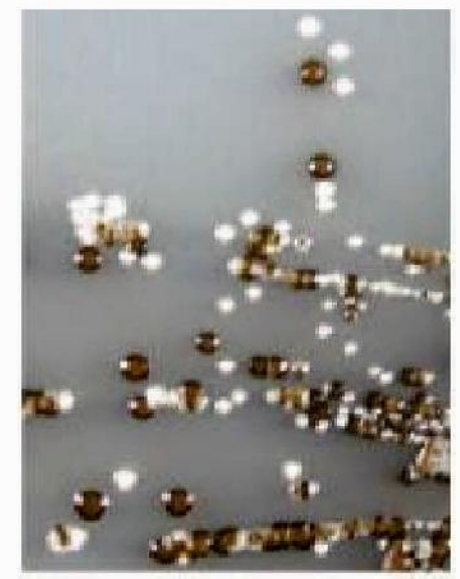

Colônias de C. neoformans em contraste com colônias de Candida albicans (brancas), destacando a produção da melanina, em meio de cultura contendo compostos fenólicos. Adaptado de Idnurm et al., 2005.

O neurotropismo do fungo pelo SNC pode ser explicado em parte pela habilidade do fungo em converter as catecolaminas norepinefrina e dopamina para produção de melanina (Casadevallet al, 2000; Steenbergen \& Casadevall, 2003). Essa hipótese é corroborada pelas observações de que áreas no cérebro ricas nesses neurotransmissores têm maior propensão para serem infectadas durante a meningoencefalite criptocócica (Casadevalletal,2000).

A melanina confere ao fungo uma proteção adicional por suas propriedades antioxidantes, protegendo-o da morte oxidativa por fagócitos (Sabiiti \&May,2012). Outros possíveis mecanismos são a proteção por parte da melanina da integridade da parede, interferência com a resposta imune celular e com a fagocitose mediada por anticorpos, bem como participação na proteção contra mudanças de temperatura e contra drogas antifúngicas (Perfect, 2010). Estudos demonstram que células melanizadas foram resistentes à morte por fármacos oxidantes e antifúngicos como Anfotericina B e Caspofungina (Van Duin; Casadevall; Nosanchuk, 2002; Sabiiti \& May, 2012) 


\subsubsection{Habilidade de desenvolvimento à $37^{\circ} \mathrm{c} /$ Termotolerância}

A maioria dos fungos patogênicos possui capacidade de bom crescimento na temperatura do corpo dos mamíferos. C. neoformans $e$ C.gattii são as únicas espécies do gênero que crescem a $37^{\circ} \mathrm{C}$. Estudos acrescentam que estirpes que não crescem bem a esta temperatura são tidos como hipovirulentos mesmo diante da cápsula e melanina, assim como os isolados de Cryptococcus sorotipo A são menos sensíveis às altas temperaturas do que o Cryptococcus sorotipo D (Martinez; Garcia-Riveira; Casadevall,2001;Garcia-Solache;Casadevall,2010).

Estudos moleculares identificaram uma variedade de genes associados ao desenvolvimento a $37^{\circ} \mathrm{C}$ (Perfect,2006). Os genes regulados pela temperatura identificados em $C$. neoformans atuam em uma variedade de processos biológicos e são apenas uma fração de alvos potenciais para inibição do desenvolvimento da levedura no hospedeiro (Perfect,2005).

O gene CNA1 codifica a calcineurina A necessária para resposta ao estresse e integridade celular em leveduras (Odom et AL., 1997). Os genes SPE3- LYS9 (espermidina sintase sacaropina desidrogenase)e ILV2 (acetolactato sintase) relacionam-se à biossíntese de aminoácidos e são necessários para sobrevivência de C. neoformans a $37^{\circ} \mathrm{C}$. Rosa e Silva e colaboradores (2008) avaliaram os genes diferencialmente expressos por $C$. neoformans a $37^{\circ} \mathrm{C}$ e identificaram produtos gênicos envolvidos em integridade da parede celular, resposta ao estresse, filamentação e metabolismo oxidativo.

Em análise genética da virulência de $C$. neoformans, Liu e colaboradores (2008) construíram 1201 mutantes nulos e identificaram dezenas de genes ainda não descritos envolvidos na produção de cápsula, síntese de melanina, crescimento a temperatura corporal e virulência. 


\subsubsection{Outros fatores de Virulência}

\subsubsection{Secreção de Enzimas}

Ambas as leveduras, C.neoformans e $C$. gattii produzem enzimas capazes de degradarem às membranas e causarem comprometimento a integridade da célula hospedeira, permitindo assim a disseminação do fungo até o cérebro (Sabiiti e May,2012).

As fosfolipases compreendem cinco classes (A1, A2, B, C e D) dependendo do sítio de hidrólise nas ligações ester fosfolipídicas. Das cinco classes de fosfolipase, a fosfolipase $B$ e $C$ estão envolvidas na virulência de Cryptococcus ssp (Cox et al, 2001; Siafakas et al, 2006). São capazes de causar uma desestabilização de membranas e consequente lise celular que estimula a infecção pulmonar e disseminação da levedura, a fosfolipase $B$ aumenta a aderência às células epiteliais pulmonares, a fagocitose por macrófagos e sua sobrevivência intracelular, assim como também contribui para aumentar a penetração da barreira hematoencefálica (Ghannoum, 2000; Soares et al,2010; Santangelo et al, 2004). Em conclusão, a fosfolipase parece exercer papel importante no escape da resposta imune do hospedeiro, na destruição de tecido pulmonar e na proteção do fungo contra ação dos macrófagos. Estudos têm verificado que esta proteção pode estar associada à produção de eicosanóides pelo fungo, modulando negativamente a função dos macrófagos (Noverr etal, 2003)

A família das proteases inclui enzimas que catalisam a clivagem de ligações peptídicas, digerindo proteínas a peptídeos ou aminoácidos livres. As proteases são importantes fatores de virulência para diversos patógenos. Em Cryptococcusneoformans é um determinante de virulência uma vez que confere a capacidade do fungo em degradar proteínas da membrana celular do hospedeiro e inativa proteínas do sistema complemento, auxiliando na invasão tecidual e no escape dos mecanismos de defesa (Ruma-Haynes et al, 2000). 
A produção de proteases pelos fungos permite maior número de fontes de nitrogênio disponíveis para esses microrganismos (Portelaetal, 2010; Rambach et al, 2010. Juntamente com as fosfolipases, as proteases causam danos à membrana fagossomal e assim, promovem a replicação de C. neoformans no interior de macrófagos, permitindo a levedura escapar da morte por enzimas fagocíticas (Tucker \& Casadevall,2002).

As ureases são metaloenzimas que catalizam a hidrólise de uréia a amônia e carbamato o que resulta em maior disponibilidade de fonte de nitrogênio e aumento do $\mathrm{pH}$ do meio onde ocorre a reação. Acredita-se que a uréase criptcocóccica é um importante fator de virulência, sendo necessária durante o processo de invasão da levedura no SNC, que ocorre através da captação da própria levedura para o interior de microcapilares do cérebro (Olszewski et al, 2004).

Nos estudos de Cox e colaboradores (2001) as linhagens nulas para o gene que codifica para esta enzima apresentaram reduzida virulência em modelos de infecção em camundongos, o que sugere a importância desta enzima na patogenicidade fúngica. Em 2010,Shi e colaboradores (2010) utilizaram modelo murino de transmigração e demonstraram que a urease criptocócica é responsável pelo aumento da transmigração da levedura até a BHE.

\subsubsection{Mating type}

O mating type (MAT) de $C$. neoformans é definido por um lócus com 2 alelos alternativos Mat a e MATa, sua identificação se dá pelo cruzamento entre isolados com tipos opostos e atualmente é realizada pela técnica de PCR, com primes específicos para cada tipo. A análise por PCR permitiu maior compreensão da epidemiologia do fungo, identificando a predominância do tipo $\alpha$, e sua relação com a virulência do fungo. Estudos conduzidos têm demonstrado a maior virulência do MAT a em relação a MAT a. Barchiese e colaboradores (2005) analisaram a patogenicidade de diferentes sorotipos e mating types de $C$. neoformans, os isolados Aa e os 
híbridos Aa/Dalevaramà morte $100 \%$ dos animais em menor intervalo de tempo quando comparados a outros sorotipos e mating types analisados.

\subsection{Diagnóstico}

Do ponto de vista laboratorial a meningite criptocócica pode ser facilmente diagnosticada através exame direto de LCR, cultivo e deteç̧ão de antígeno capsular (Lazéra et al, 2005).

A levedura também pode ser observada ao microscópio a partir de uma grande variedade de materiais clínicos: líquor, urina, fragmentos de tecido, aspirado de lesões cutâneas e medula óssea, escarro e secreções do trato respiratório. Normalmente, o diagnóstico baseia-se no achado microscópico de leveduras encapsuladas evidenciadas por tinta de china, no crescimento de fungo em cultura e na detecção do antígeno capsular e material genético em amostras biológicas apresentando esta maior sensibilidade e rapidez no diagnóstico (Lacaz et al, 2002; Perfect \&Casadevall, 2002; Kon et al, 2008). A pesquisa direta em tinta de china consiste na visualização da cápsula em contraste negativo. A sensibilidade como método diagnóstico é baixa em torno de $30-50 \%$ em pacientes sem AIDS e de $80 \%$ para pacientes com AIDS (Perfect, 2010; Chayakulkere \& Perfect, 2006).

Sempre que possível a pesquisa direta de Cryptococcus deve está associada à técnica de cultivo do microrganismo. Cryptococcus cresce bem em vários meios de cultivos e em temperaturas entre 25 a $37^{\circ} \mathrm{C}$. Os meios de cultura mais utilizados são o Ágar-Sabouroud e Ágar-niger, neles as colônias de $C$. neoformans e $C$. gattii se apresentam de coloração que variam entre o branco e o creme, de aspecto brilhante e textura mucóide decorrente da produção de melanina pelo fungo. Na maioria dos meios de rotina do laboratório, colônias do fungo aparecem dentro 1 a 3 dias (48 a 72 horas) (Lazéra; Igreja; Wanke, 2004). 
Embora a cultura seja considerada o padrão-ouro para diagnóstico o método requer maiores quantidades de amostra, aliado a infraestrutura laboratorial (centrifugação). O LCR deve ser centrifugado para realização do exame direto e cultura. Em alguns casos, os resultados negativos podem ser atribuídos ao acondicionamento inadequado da amostra após coleta, transporte e processamento das amostras por profissionais não especializados. A sensibilidade em pacientes imunocompetentes é de $89 \% \mathrm{e}$ de 95 a 100\% em pacientes com HIV(Fries et al, 2001; Lacaz et al, 2002; Kon et al, 2008).

Os testes imunológicos como a reação de aglutinação para detecção do antígeno polissacarídeo circulante no soro e LCR são realizados a partir do LCR ou soro de pacientes com suspeita clínica de Criptococose demonstrando alta sensibilidade e especificidade, com sensibilidade de $90 \%$ em pacientes com meningoencefalite criptocócica são considerados menos trabalhosos e demorados quando comparados a cultura. No entanto, requerem condições de refrigeração, transporte e conhecimentos especializados por parte dos profissionais envolvidos na análise; assim sua realização condiciona a laboratórios de referência e os custos não são acessíveis para a prática clínica (Kon et al, 2008; Lindsley et al, 2011).

Os testes sorológicos são sensíveis, específicos e permitem um diagnóstico rápido e seguro quando disponíveis. O método de aglutinação de látex consiste na utilização de partículas de látex sensibilizadas com anticorpos policlonais hiperimunes contra antígenos da cápsula polissacarídea do $C$. neoformans; quando entram em contato com amostras que contém estes antígenos realizam uma reação de aglutinação detectando e quantificando aproximadamente $3.2 \mathrm{ng} / \mathrm{ml}$ de antígenos capsulares em LCR ou soro (Mitchel \& Perfect, 1995). Esta técnica tem indicação na detecção e acompanhamento do tratamento do paciente com neurocriptococose e tem sido empregada diante de resultados negativos para cultura e pesquisa direta. $O$ teste tem aproximadamente $95 \%$ de sensibilidade e especificidade (Stevenset al,2002).

Em 2009, desenvolveu-se o teste de imunoensaio de fluxo lateral (LFA) para a detecção de antígenos criptocócicos sendo hoje considerado 
uma ferramenta potencial para detecção de Cryptococcus neoformans e Cryptococcus gattii. Consiste em tiras impregnadas com anticorpos monoclonais para detectação dos quatros sorotipos criptocócicos e um diluente. O kit de LFA é estável à temperatura ambiente, durante até um ano. O exame tem rápido tempo de resposta, requer mínima habilidade técnica e pode ser realizada com infra-estrutura laboratorial mínima. Os resultados são obtidos de 5 minutos a 15 minutos de acordo com as instruções do fabricante. Para análise, a presença de duas bandas (banda de controle e banda teste) é interpretada como um resultado positivo e uma única banda na zona de teste ( banda de controle ) é interpretado como um resultado negativo.

Os métodos moleculares baseiam-se na identificação de sequências de DNA e RNA são realizados diretamente a partir de amostras biológicas como LCR, urina, escarro, soro. As sequências de DNA geradas por PCR e sequenciamento são consideradas promissoras. A técnica mais utilizada em fungos é a amplificação de rDNA por reação da polimerase em cadeia (PCR). Esta técnica permite a amplificação de regiões específicas do genoma, no entanto, a utilização desta metodologia torna-se inviável para a rotina de diagnóstico de $C$. neoformans devido ao alto custo em relação às técnicas convencionais.

Apesar dos avanços nas técnicas diagnósticas, o Cryptocococcusapresenta variações morfológicas que dificultam o seu reconhecimento, como em seu tamanho, a espessura da cápsula ou de ambos. Além disso, ocorrem formas não capsuladas, ora de tamanho médio, ora de tamanho pequeno (Stevenset al,2002).

O diagnóstico tardio aliado às dificuldades em controlar a infecção são importantes causas da mortalidade e morbidade o que se torna imperativo o empenho no diagnóstico precoce aliado ao tratamento adequado (Perfectet al, 2010). 


\subsection{Tratamento}

O tratamento da Criptococose continua sendo um importante desafio com pouco desenvolvimento de medicamentos novos ou estudos recentes. O principal objetivo do tratamento é a negativação em cultivo do microrganismo a fim de prevenir sequelas neurológicas e mortes. $\mathrm{O}$ fato das infecções fúngicas representarem parasitismo de um organismo eucariótico sobre outro eucariótico, com diferenças fisiológicas extremamente pequenas, faz-se necessário que as drogas antifúngicas tenham aplicação clínica adequada, com o mínimo de efeitos colaterais (Lacaz \& Negro, 1991)

Para Perfect et al (2010) o uso apropriado dos antifúngicos diminui a mortalidade significativamente, mas requer terapia contínua e prolongada para prevenir recidivas. Quando o diagnóstico é feito precocemente e se houver adesão dos profissionais na terapêutica padronizada com concomitante controle da doença de base; a criptococose pode ser enfrentada com sucesso na grande maioria dos pacientes.

\subsubsection{Classes de drogas antifúngicas utilizadas no tratamento da Criptococose}

O ritmo da descoberta e desenvolvimento de antifúngicos é excessivamente lento. A Sociedade de Doenças Infecciosas dos Estados Unidos e a Organização Mundial da Saúde (OMS) emitiram recentemente uma atualização das Diretrizes de Tratamento, mas na rotina dos serviços a indisponibilidade de drogas dificultam a implementação dessas recomendações.

Atualmente existem três classes de drogas antifúngicas: os poliênicos (anfotericina B em apresentação de desoxicolato, lipossomal e coloidal), os azóis (cetoconazol, itraconazol, fluconazol e voriconazol) e o derivado 
piramidínico (5-flucitosina) que começaram a ser empregados na prática clínica somente em 1980. Desde esta época há uma carência por novos agentes antifúngicos de uso terapêutico (Oddset al, 2003).

A descoberta dos triazóis na década de 80 , sendo o fluconazol o que demonstrou maior atividade contra o $C$. neoformans, coincidiu com 0 surgimento da pandemia de AIDS e intenso aumento da incidência de Criptococose associada a esta doença. Tendo em vista este cenário, vários estudos foram realizados com o objetivo de se definir o melhor esquema terapêutico para esta micose.

Os azóis induzem à depleção do ergosterol e estão divididos em imidazóis como, miconazol e cetoconazol e os triazóis como fluconazol e itraconazol. Dentre estes citados o fluconazol e o itraconazol apresentam maior eficácia e baixa toxicidade. Os triazóis inibem a enzimado citocromo P-450 dos fungos que é responsável pela síntese do ergosterol da membrana citoplasmática o que pode resultar emdistúrbios em enzimas hepáticas fazendo-se necessário o monitoramento freqüente dos níveis séricos (Pauw, 2000).

Em 1989, ensaio terapêutico comparando-se a anfotericina B, associada ou não à flucitosina, com o fluconazol, concluiu que ambas as opções eram aceitáveis. Todavia o fluconazol apresentou melhor desempenho em pacientes com baixo risco de falha terapêutica. Larsenet al(1990) publicou estudo semelhante em quedemonstrou que a combinação de anfotericina $B$ com flucitosina é superior ao uso isolado de fluconazol. $O$ itraconazol também foi comparado com a anfotericina $B$ associado à flucitosina para o tratamento da Criptococose na AIDS, mostrando menos eficácia.A taxa de sucesso terapêutico do fluconazol aumenta com a associação da flucitosina, o que foi demonstrado em outro trabalho de Larsen e colaboradores (Larsenet al, 1994).

Apesar de sua toxicidade, a anfotericina B continua sendo a droga de escolha no tratamento de infecções fúngicas sistêmicas. Seu mecanismo de atuação se dápor meio do aumentoda permeabilidade da membrana celular fúngica, ligando-se ao ergosterol presente na membrana citoplasmática 
provocando sua desestruturação e produzindo poros. Ela também interage com o colesterol na membrana celular humana, o que provavelmente determina a sua toxicidade e obriga a interrupção do tratamento. Entretanto, esta droga apresenta um amplo espectro de atividade sendo comumente usada no tratamento de infecções sistêmicas causadas por leveduras em pacientes imunocomprometidos (Wasan et al, 1997; Pauw, 2000).

A anfotericina-B desoxicolato tem sido considerada o padrão ouro para otratamento das infecções fúngicas mais graves. $O$ desenvolvimento de novasformulações de anfotericina- $B$, as quais usam lipossomas ou complexos lipídicos comosistema de liberação representa um avanço importante no tratamento de infecções fúngicas, devidoaos seus perfis de segurança favoráveis e farmacocinética. Entretanto o efeito fungicida da droga contra o $C$. neoformans depende da concentração usada, o tipo celular e de um bom veículo de condução (Araujo et al, 2005)

A 5-flucitosina constitui um análogo da droga antineoplásica 5fluorouracil atua incorporando-se ao RNA e inibindo asíntese de ácidos nucléicos. Possui uma boa penetração em diferentes cavidades do corpo, incluindo o fluido cerebroespinhal, mas o uso clínico é limitado pela ocorrência de resistência primária, bemcomo de resistência adquirida, particularmente quando utilizada isoladamente. Altasdoses de 5 -flucitosina podem suprimir a hematopoiese (Pauw, 2000).

As equinocandinas atuam inibindo a síntese de B-1,3-glucana da parede fúngicaerepresentam o primeiro alvo novo, em vinte anos de descoberta de antifúngicos, emtermos de drogas de uso clínico (Odds et al, 2003).

A combinação sinérgica de antifúngicos tem diversas vantagens, incluindo o potencialpara diminuição do desenvolvimento de resistência às drogas, um amplo espectro antifúngico e uma redução potencial na dose e toxicidade de cada medicamento (Lupetti et al, 2003). 


\subsubsection{Esquemas terapêuticos atualmente preconizados}

Segundo as "Diretrizes Práticas para tratamento da Doença Criptocóccica", atualizada em 2010 pela Sociedade de Doenças Infecciosas dos Estados Unidos, o tratamento dos pacientes com quadro de meningoencefalite criptocócica em três grupos de risco:

(1) indivíduos infectados pelo vírus da imunodeficiência humana (HIV);

(2) receptores de transplante de órgãos, e

(3) não-infectado pelo HIV e não transplantados;

Há recomendações específicas para outras populações de risco únicas, como a crianças, mulheres grávidas, pessoas em ambientes de recursos limitados, e aqueles com infecção Cryptococcus gattii. Existem ainda recomendações para o tratamento em outros locais de infecção, incluindo estratégias para Criptococose pulmonar. As possíveis complicações como aumento da pressão intracraniana, a síndrome de reconstituição imune inflamatória (IRIS), resistência a drogas, e criptococomas foram abordados.

A abordagem terapêutica em indivíduos com meningoencefalite infectados pelo HIV envolve três fases conforme demonstrado na tabela 3 , sendo a primeira de redução da carga de fungos no organismo do paciente, chamada fase de indução. A Organização Mundial da Saúde (OMS) e a Sociedade de Doenças Infecciosas dos Estados Unidos recomendam que essa primeira linha de ataque seja feita com a combinação de dois antifúngicos, a anfotericina $B(A M B)$ e 5 -flucitosina (5FC). No Brasil e em vários outros países em desenvolvimento, da Ásia e da África, o 5FC não se encontra disponível, no entanto. A utilização da $5 F C$ com a $A M B$ ainda é a melhor opção terapêutica, com a menor taxa de mortalidade. 
Tabela 2 - Recomendações de Tratamento Antifúngico para Meningoencefalite Criptocócica em indivíduos infectados pelo HIV

\begin{tabular}{|c|c|c|}
\hline Regime & Duração & Evidência \\
\hline \multicolumn{3}{|l|}{ Terapia de Indução } \\
\hline $\begin{array}{l}\text { Anfotericina B desoxicolato }(0.7-1.0 \mathrm{mg} / \mathrm{kg} \text { por dia) mais } \\
\text { flucitosina ( } 100 \mathrm{mg} / \mathrm{kg} \text { por dia) }\end{array}$ & 2 semanas & $A-I$ \\
\hline $\begin{array}{l}\text { Anfotericina B lipossomal (3-4 mg / kg por dia) ou } \\
\text { ABLC ( } 5 \mathrm{mg} / \mathrm{kg} \text { por dia) mais flucitosina ( } 100 \mathrm{mg} / \mathrm{kg} \text { por } \\
\text { dia) em pacientes com quadro de disfunção renal }\end{array}$ & 2 semanas & B- II \\
\hline $\begin{array}{l}\text { Anfotericina B desoxicolato }(0.7-1.0 \mathrm{mg} / \mathrm{kg} \text { por dia) ou } \\
\text { Anfotericina B lipossomal (3-4 } \mathrm{mg} / \mathrm{kg} \text { por dia) ou ABLC ( } 5 \\
\mathrm{mg} \mathrm{/} \mathrm{kg} \text { por dia) para pacientes com intolerância a } \\
\text { flucitosina }\end{array}$ & 4-6 semanas & B- II \\
\hline
\end{tabular}

Alternativas para a terapia de indução $b$

AmBLipossomal (6 mg / kg por dia) ou ABLC ( $5 \mathrm{mg} / \mathrm{kg}$ por $4-6$ semanas B-III dia)

\begin{tabular}{|c|c|c|}
\hline AmBd mais fluconazol & $\ldots$. & B-I \\
\hline Fluconazol mais flucitosina & $\ldots$ & B-II \\
\hline Fluconazol & .... & B-II \\
\hline Itraconazol & $\ldots$ & C- II \\
\hline \multicolumn{3}{|c|}{ Terapia de Consolidação } \\
\hline Fluconazol (400 mg por dia) & 8 semanas & $A-I$ \\
\hline \multicolumn{3}{|c|}{ Terapêutica de manutenção } \\
\hline Fluconazol (200 mg por dia) & $\geq 1$ ano $c$ & $A-I$ \\
\hline \multicolumn{3}{|c|}{ Alternativas para a terapia de manutenção } \\
\hline Itraconazol (400 mg por dia) d & $\geq 1$ ano $c$ & C-I \\
\hline Anfotericina B desoxicolato (1.0 mg/kg por semana) $\mathrm{d}$ & $\geq 1$ ano $\mathrm{c}$ & C-I \\
\hline
\end{tabular}

Fonte: Adaptado de Perfect et al (2010).

NOTA. ABLC, a anfotericina B complexo lipídico; AmB, anfotericina B; AmBd, anfotericina $B$ desoxicolato, HAART: terapia antiretroviral

iniciar a terapia antiretroviral 2 semanas após início do tratamento antifúngico inicial.

b Em situações clínicas exclusivas em que recomendações primárias não estão disponíveis, a consideração de regimes alternativos pode ser feita, mas não deve ser incentivada como substitutos.

c Com introdução bem sucedida de HAART, uma contagem de células CD4 maior ou igual a 100 células / mL ecarga viral baixa ou não detectável nos últimos 3 meses, com mínimo de 1 ano de tratamento antifúngico.

d recomendação inferior à primária. 
Estudo que envolveu 236 pacientes tratados com anfotericina $B+$ flucitosina, evidenciou melhor prognóstico no grupo de pacientes com cultura negativa no LCR na $2^{\text {a }}$ semana de tratamento, reforçando ser uma das metas de escolha no tratamento da neurocriptococose (Robinson et al; 1999). A terapia de indução para meningoencefalite utilizando anfotericina $B$ desoxicolato, 0,7-1,0 mg/Kg/dia, associada a flucitosina $100 \mathrm{mg} / \mathrm{Kg} / \mathrm{dia}$, pelo menos por duas semanas divididas em quatro doses. Com resposta clínica de sucesso, a terapêutica pode ser trocada por fluconazol, 400 a $800 \mathrm{mg} / \mathrm{dia}$ durante 8 a 10 semanas. Outra alternativa é a utilização de anfotericina $B$ lipossomal, principalmente em casos graves, pacientes com disfunção renal ou sem ingestão oral efetiva.O esquema deve ser instituído por pelo menos 2 semanas, seguido de fluconazol $400 \mathrm{mg} / 6 \mathrm{mg} / \mathrm{kg} /$ por dia por via oral) por um período mínimo de 8 semanas (A-I). Na dose de3-4 $\mathrm{mg} / \mathrm{kg}$ por dia de anfotericina $B$ lipossomal IV ou $5 \mathrm{mg} / \mathrm{kg}$ por dia de e anfotericina $B$ formulações lipídicas IV por pelo menos dois semanas em pacientes com ou predispostos a disfunção renal.

Um estudo randomizado duplo cegodemonstrou não haver inferioridade na substituição da anfotericina lipossomal (3 e $6 \mathrm{mg} / \mathrm{kg} / \mathrm{dia}$ ) pela anfotericina $B$ desoxicolato $0,7 \mathrm{mg} / \mathrm{kg} / \mathrm{dia}$ e o grupo que usou anfotericina lipossomal 3mg/kg/dia apresentou menos efeitos colaterais (HAMIL et al.; 2010).

Após as duas semanas da fase de indução inicia-se a fase de consolidação com fluconazol na dose de $400 \mathrm{mg} /$ dia em uma única tomada por oito semanas ou até negativação das culturas de LCR. O itraconazol é uma alternativa na dose de $400 \mathrm{mg} / \mathrm{dia}$, todavia menos efetiva. A fase de manutenção é instituída após o tratamento efetivo, e objetiva a redução do número de recaídas, sendo utilizado o fluconazol na dose de $200 \mathrm{mg} / \mathrm{dia}$ por período indefinido podendo ser superior a 12 meses. Outras opções incluem a anfotericina $B$ desoxicolato $1 \mathrm{mg} / \mathrm{Kg}$ por semana e itraconazol $400 \mathrm{mg} / \mathrm{dia}$.

A tabela 4 ilustra a terapêutica a ser implementada a pacientes sem status sorológico deinfecção pelo HIV e não transplantados. 
Tabela 3 - Recomendações de Tratamento Antifúngico para Meningoencefalite Criptocócica em pacientes humanos não infectados pelo HIV e não transplantados

\begin{tabular}{|c|c|c|}
\hline Regime & Duração & Evidência \\
\hline \multicolumn{3}{|l|}{ Terapia de indução } \\
\hline $\begin{array}{l}\text { AmBd }(0,7-1,0 \mathrm{mg} / \mathrm{kg} \text { por dia) mais flucitosina }(100 \mathrm{mg} / \mathrm{kg} \\
\text { por dia) }\end{array}$ & $\begin{array}{l}\geq 4 \\
\text { semanas }^{a}\end{array}$ & B-II \\
\hline AmBd $(0,7-1,0 \mathrm{mg} / \mathrm{kg} \text { por dia })^{\mathrm{c}}$ & $\begin{array}{l}\geq 6 \\
\text { semanas }^{a}\end{array}$ & B-II \\
\hline $\begin{array}{l}\text { AmBLipossomal (3-4 mg / kg por dia) ou ABLC (5 mg / kg por } \\
\text { dia) combinada com flucitosina, se possível }{ }^{d}\end{array}$ & $\begin{array}{l}\geq 4 \\
\text { semanas }^{a}\end{array}$ & B-III \\
\hline $\begin{array}{l}\text { AmBd }(0,7 \mathrm{mg} / \mathrm{kg} \text { por dia) mais flucitosina (100 mg / kg por } \\
\text { dia) }\end{array}$ & 2 semanas & B-II \\
\hline Terapêutica de consolidação: fluconazol (400-800 mg por dia) ${ }^{\dagger}$ & 8 semanas & B-III \\
\hline Terapêutica de manutenção: fluconazol (200 mg por dia) ${ }^{\text {b }}$ & $\begin{array}{l}6 \text { a } 12 \\
\text { meses }\end{array}$ & B-III \\
\hline
\end{tabular}

\section{Fonte: Adaptado de Perfect et al, 2010}

NOTA.ABLC, a anfotericina B complexo lipídico; AmB, anfotericina B; AmBd, anfotericina B desoxicolato.

a Quatro semanas são reservados para pacientes com meningite que não têm complicações neurológicas, que não têm doenças subjacentes significativos ou imunodepressão, e para os quais a cultura líquido cefalorraquidiano realizada no fim de 2 semanas de tratamento não produz leveduras viáveis; durante o segundo de 2 semanas, as formulações lipídicas de AmB pode ser substituído por AmBd.

${ }^{B}$ O fluconazol é ministrado a $200 \mathrm{mg}$ por dia para prevenir recaídas após a terapia de indução, e terapêutica de consolidação é recomendada.

${ }^{\mathrm{C}}$ Para os pacientes intolerantes a flucitosina.

${ }^{\mathrm{d}}$ Para os pacientes intolerantes a AmBd.

ePara os pacientes que têm um baixo risco de falha terapêutica. Baixo risco é definido como um diagnóstico precoce pela história, nenhuma condição descontrolada subjacente ou imunocomprometidos estado grave, e uma excelente resposta clínica à inicial de 2 semanas de curso de combinação antifúngica.

f Uma dosagem mais elevada de fluconazol (800 mg por dia) é recomendado se foi usado o regime de indução de duas semanas, e se há uma função renal normal.

Para tratamento das formas pulmonares leve a moderada tanto em pacientes imunocompetentes como em imunossuprimidos existe indicação de fluconazol 400/dia mg /dia se mantendo por período de 6 a 12 meses e nos 
casos graves aplica-se o mesmo tratamento abordado em casos de doença do SNC por um período de 12 meses conforme ilustra a tabela 6 .

Tabela 4 - Recomendações de Tratamento Antifúngico para Criptococose Não Meníngea

\begin{tabular}{|c|c|c|c|}
\hline Grupo de Pacientes & $\begin{array}{c}\text { Regime } \\
\text { antifúngico } \\
\text { inicial }\end{array}$ & Duração & Evidência \\
\hline $\begin{array}{l}\text { Pacientes imunodeprimidos } \\
\text { eimunocompetentes com Criptococose } \\
\text { pulmonar leve a moderada }\end{array}$ & $\begin{array}{l}\text { Fluconazol } \\
\text { (400 mg por } \\
\text { dia) }\end{array}$ & $\begin{array}{l}6 \text { a } 12 \\
\text { meses }\end{array}$ & B-III \\
\hline $\begin{array}{l}\text { Pacientes imunodeprimidos }{ }^{\mathrm{a}} \mathrm{e} \\
\text { imunocompetentes com Criptococose } \\
\text { pulmonar grave }\end{array}$ & $\begin{array}{l}\text { Mesmo } \\
\text { como } \\
\text { doença do } \\
\text { SNC }\end{array}$ & 12 meses & B-III \\
\hline \multicolumn{4}{|c|}{ Pacientes com Criptococose não meníngea, não pulmonar } \\
\hline Pacientes com Criptococose & $\begin{array}{l}\text { Mesmo } \\
\text { como } \\
\text { doença do } \\
\text { SNC }\end{array}$ & 12 meses & B-III \\
\hline $\begin{array}{l}\text { Pacientes para os quais doenças do SNC } \\
\text { foram descartadas, sem fungemia, com um } \\
\text { único local da infecção, e sem fatores de } \\
\text { risco de imunossupressão }\end{array}$ & $\begin{array}{l}\text { Fluconazol } \\
400 \text { mg por } \\
\text { dia }\end{array}$ & $\begin{array}{l}6 \text { a } 12 \\
\text { meses }\end{array}$ & B-III \\
\hline
\end{tabular}

Fonte: Adaptado de Perfect et al., 2010

NOTA.SNC, Sistema Nervoso Central.

${ }^{a} A$ doença do SNC deve ser monitorada com punção lombar

Em manifestações pulmonares em pacientes sem histórico de infecção pelo HIV preconiza-se o uso do fluconazol, itraconazol e anfotericina $B$ dependendo da positividade da cultura liquórica. Nos casos de infecção do SNC e meningoencefalite criptocócica as drogas disponíveis são anfotericina B formulações lipídicas, itraconazol e fluocitosina (5-FC); nas fases de consolidação, que compreende o período de manutenção de 
negatividade micológica e normalização de parâmetros clínicos e laboratoriais, preconiza-se o uso do fluconazol (MORETTI et al.,2008).

Para o planejamento terapêutico é imprescindível conhecer a extensão da doença, em especial a presença ou não do acometimento do SNC. Nos casos de criptocococe pulmonar, é fundamental garantir que a doença não seja disseminada, devido á necessidade de se tratar mais efetivamente a neurocriptococose.

\subsubsection{Hipertensão intracraniana (HIC)}

A hipertensão intracraniana (HIC) ocorre em aproximadamente $50 \%$ dos pacientes com neurocriptococose, contribuindo para significativo aumento da morbimortalidade da doença (Saag et al, 2000).

Defini-se HIC como aumento da pressão liquórica inicial medida por raquimanometria $\geq 200 \mathrm{mmH} 20$ com o paciente em decúbito lateral. O adequado diagnóstico e manejo terapêutico são fundamentais para diminuição da morbidade e mortalidade em pacientes.

Clinicamente, os pacientes com HIC podem se apresentar com sinais e sintomas característicos como hipertensão arterial sistêmica, diminuição do sensório, alteração dos nervos cranianos, diminuição da acuidade visual e audititva, papiledema, alteração dos reflexos e cefaleia intensa (Mitchell \& Perfect, 1995). Entretanto, estes achados podem estar ausentes. Desta forma, o controle da HICse dá por meio da aferição da pressão de abertura liquórica por punção lombar com raquimanometria.A exclusão de lesões de massa pela tomografia computadorizada de crânio é necessária para realização dapunção lombar (Graybillet al, 2000).

Uma vez diagnosticada, existem várias opções terapêuticas disponíveis, no entanto os estudos não são consistentes em garantir a melhor alternativa. A principal intervenção descrita para redução da HIC é a punção lombar intermitente. Entretanto em casos refratários quando há falhas das punções sequenciais em controlar os níveis pressóricos e os 
sinais e sintomas ou déficits neurológicos persistem ou são progressivos, uma derivação ventrículo-peritonial está indicada.

No Brasil, segundo a OMS (2011) e o Consenso em Criptococose (2008) o fluxograma de acompanhamento de pacientes é determinado a partir dos achados dapressão liquórica eresultados da tomografia de crânio e algumas medidas para abordagem da HIC estão descritas nas figuras abaixo.

Figura 6: Manejo da hipertensão intracraniana secundária a doença criptocócica

- Se a pressão de abertura liquórica for superior a $25 \mathrm{~cm} \mathrm{H} 20$ e estiverem presentes sinais de edema cerebral, esta deve ser reduzida em $50 \%$ da pressão inicial por meio de punção lombar de alívio (normalmente com retirada de 20 a $30 \mathrm{~mL}$ de líquor).

- A PL de alívio deve ser repetida diariamente até a estabilização da pressão intracraniana (PIC).

- Na presença de PIC estável e normal em duas aferições consecutivas, recomendase punção lombar semanal para monitoramento de resposta terapêutica.

- Se a PIC se mantiver persistentemente elevada após duas semanas de PL diária, considerar a abordagem neurocirúrgica para derivação liquórica.

Manitol ou acetazolamida não devem ser utilizados no manejo de HIC secundária a criptococose.

Fonte: OMS (2011) 
Figura 7: Manejo da hipertensão intracraniana associada à meningoencefalite criptocócica

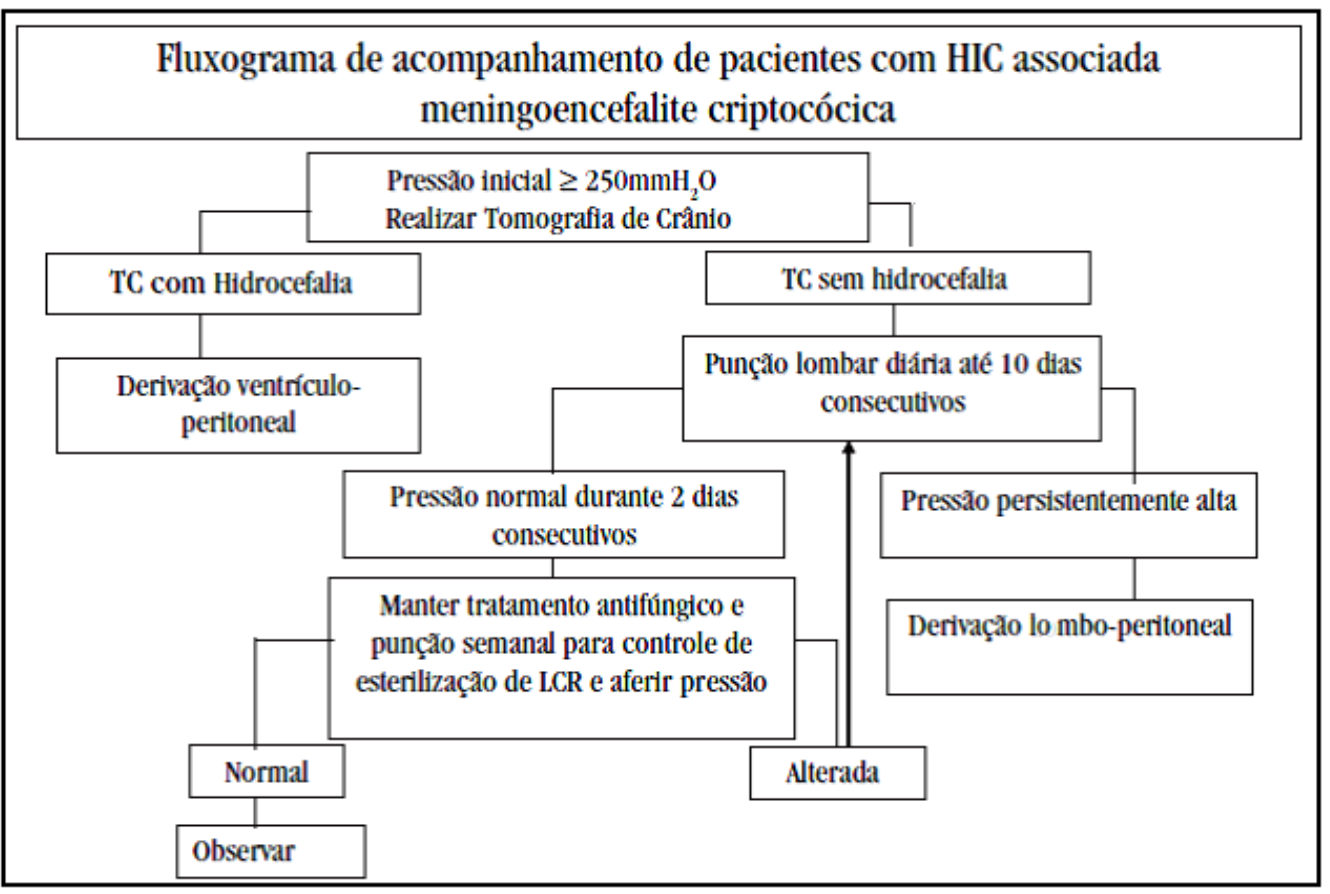

Disponível em: Consenso em Criptococose (2008)

\subsubsection{Prevenção}

As terapias antifúngicas atuais têm sido muitas vezes ineficazes, devido à toxicidade do fármaco, o surgimento de organismos resistentes a fármacos, e / ou a incapacidade das defesas imunológicas do hospedeiro emauxiliar na erradicação da levedura. Portanto, existe urgência no desenvolvimento de terapias de base imunitária e / ou vacinas para combater a Criptococose.

Atualmente, estudos em modelos animais demonstram a eficácia das várias estratégias de vacinação e terapias imunológicas para induzir proteção contra Criptococose. Uma vacina constituída por uma proteína sintetizada GXM- conjugada a um heptapolissacarídeo pode ser um potencial avanço na indução de produção de anticorpos monoclonal específico contra a Criptococose. Embora tenham sido desenvolvidos, os 
ensaios clínicos em seres humanos encontram-se na fase inicial de determinação de toxicidade. Sem dúvida são necessários mais estudos quanto àeficácia, a avaliação da resposta e risco para o paciente e o custobenefício das estratégiasimunológicas passiva ou ativa. 


\section{JUSTIFICATIVA}

Cryptococcus neoformans e C. gattii são fungos patogênicos com ampla distribuição mundial, agentes da criptococose, micose sistêmica com elevada morbidade e letalidade. Estudos sorológicos das populações humanas mostram uma alta prevalência de infecção humana, o que raramente progride para a doença em hospedeiros imunocompetentes. No entanto, a diminuição da imunidade do hospedeiro coloca os indivíduos com alto risco de doença criptocócica. Tendo em vista a gravidade da Criptococose, o aumento significativo de sua ocorrência e ausência de estudos até os dias de hoje a respeito do perfil epidemiológico dessa micose no Distrito Federal, o estudo deta micose se faz relevante uma vez que descreve as características clínicas e sócio demográficas de pacientes atendidos em unidades hospitalares da rede pública do Distrito Federal (DF) que tiveram diagnóstico confirmado laboratorialmente de infecção fúngica pelo Cryptococcus.

Apesar de a Criptococose vir ganhando importância como problema de saúde pública no Brasil e no mundo, muitos aspectos da epidemiologia desta doença ainda são pouco conhecidos, com registros em bases de dados somente quando a criptococose assume caráter oportunista em pacientes com HIV ou diante da existência de surtos, dificultando a suspeição clínica e tratamento precoce e adequado. Baseado nos resultados obtidos, o estudo fornecerá importantes contribuições para futuros estudos e para o conhecimento do comportamento desta micose no Distrito Federal. 


\section{OBJETIVOS}

\subsection{Objetivo Geral}

Caracterizar os aspectos clínicos, laboratoriais e epidemiológicos dos casos de Criptococose diagnosticados entre os anos de 2006 a 2013 e atendidos na rede pública de saúde do Distrito Federal.

\subsection{Objetivos Específicos}

- Determinar as características clínicas e laboratoriais da Criptococose em hospedeiro com e sem fatores predisponentes associados no DF;

- Descrever o perfil epidemiológico e a evolução clínica dos casos de criptococose primária e oportunista no Distrito Federal;

- Identificar a frequência de isolamento de $C$. neoformans nos diferentes anos de diagnóstico, caracterizando as formas clínicas e distribuição geográfica da Criptococose no Distrito Federal.

\section{MÉTODOS}

No intuito de compreender as especificidades do perfil epidemiológico da Criptococose no Distrito Federal a presente pesquisa analisou o perfil da Criptococose segundo as variáveis: sexo, idade, naturalidade, procedência, ocupação, unidade de atendimento, ano do diagnóstico, sintomatologia, status imunológico e achados laboratoriais de sangue e líquor, presença de comorbidades, conduta terapêutica e evolução; utilizando questionário de pesquisa (anexo 1). Para o estudo do tema em questão, optou-se pela escala temporal, que marca o período de 2006 a 2013 tendo em vista a disponibilidade de registros de resultados laboratoriais devidamente documentados junto ao sistema de informação da Secretaria de Saúde do Distrito Federal. 


\subsection{Delineamento do Estudo}

Estudo retrospectivo, analítico de série de casos para levantamento e caracterização dos casos de Criptococose no Distrito Federal, tendo como base os registros hospitalares (prontuários e bases laboratoriais) de pacientes com diagnóstico de Criptococose dos últimos 7 anos (2006-2013).

\subsection{Coleta de dados}

- A busca pelos dados ocorreu a partir dos seguintes instrumentos:

- registros hospitalares disponíveis através do prontuário eletrônico ou impresso;

- bases eletrônicas do Laboratório Central (LACEN) e laboratório do hospital de Base do Distrito Federal (HBDF);

- bases eletrônicas disponíveis na rede SUS de saúde do Distrito Federal (TRACK CARE).

\subsection{População do Estudo}

Foram incluídos indivíduos de ambos os sexos e todas as faixas etárias, com diagnóstico clínico - laboratorial de Criptococose primária ou associada a co-infecção pelo HIV ou a outros fatores predisponentes doenças malignas, transplantes, diabetes, uso de corticóide e/ou outros imunossupressores e imunobiológicos (rituximab, etc), cirrose, doenças inflamatórias crônicas, tuberculose, gravidez e outros).

\subsection{Critérios de Inclusão}


Foram considerados pacientes com Criptococose aqueles que apresentaram pesquisa direta positiva ou cultura positiva para Cryptococcus spp; em qualquer espécime, conforme descrito abaixo:

a. Líquido Cefalorraquidiano (LCR) - exame direto positivo ou cultivo positivo ou látex positivo; Hemocultura, urina, e outros espécimes clínicos (exceto escarro), biópsia de qualquer tecido positivo em cultivo.

b. Escarro positivo em cultivo com lesão pulmonar suspeita.

c. Plasma ou soro com látex positivo para o antígeno capsular de Cryptococcus sp. : caso provável, análise individual de caso.

\subsection{Critérios de exclusão}

Todo paciente sem confirmação do diagnóstico etiológico pelos critérios laboratoriais discriminados acima.

\subsection{Levantamento e análise dos prontuários nas unidades hospitalares do Distrito Federal}

Mediante a devida aprovação do projeto pelo Comitê de Ética em Pesquisa, foram levantados os resultados positivos a partir dos registros existentes junto ao Departamento de Micologia do Laboratório Central do Distrito Federal considerado o local de referência para recebimento e análise de amostras provenientes da rede pública do Distrito Federal. Da pesquisa inicial foi obtida uma totalidade de 89 registros dos quais após avaliação de duplicidade alcançou-se 88 resultados positivos para Cryptococcus neoformans em pesquisa direta e cultura.

O Laboratório Central de Saúde Pública do DF - LACEN-DF, é um órgão vinculado à Subsecretaria de Vigilância à Saúde, da Secretaria de Estado de Saúde. Tem como objetivo realizar pesquisas científicas e exames laboratoriais como atividades de vigilância sanitária e epidemiológica. Na área de Biologia Médica realiza, para a rede pública de 
Saúde do DF, que compreende 12 hospitais, 61 centros de saúde, 3 unidades mistas de saúde, 7 postos de saúde urbanos e 23 postos de saúde rurais, exames laboratoriais para o diagnóstico e controle, de mais de 30 doenças transmissíveis, dentre as quais se destacam AIDS, tuberculose, meningite, dengue, hepatite, leptospirose, cólera e difteria.

Em conseguinte, realizou-se visita aos Núcleos de Arquivo Médico das unidades hospitalares de atendimento dos casos para coleta e análise de dados a partir dos prontuários. Nesta fase houve perda de 01 prontuário físico, devido a não localização do mesmo em nenhuma das unidades hospitalares, assim foram analisados 87 prontuários.

A partir desses dados, tornou-se possível uma caracterização geral dos casos de Criptococose, tendo em vista suas especificidades. Nessa etapa identificou-se limitação ou a precariedade das informações, com prontuários pouco consistentes e ausência das informações relevantes para o acompanhamento do paciente e definição da pesquisa.

Outra dificuldade encontrada na pesquisa documental diz respeito à disponibilização dos prontuários nas unidades de atendimento, assim os gestores responsáveis pelo Núcleo de Arquivo Médico de cada Unidade de Saúde foram contatados com antecedência via telefone e ofício para a disponibilização dasinformações. No entanto,em alguns casos mesmo após intensa dedicação por parte dos envolvidos as informaçõesnão foram integralmente disponibilizadas.

\subsection{Processamento e Análise Estatística dos Dados}

Todas as informações coletadas através da revisão de prontuários foram codificadas e armazenadas em banco de dados com a utilização do software Excel®.Posteriormente, os dados foram representados na forma de tabelas, gráficos e mapas. Os mapas de fluxo e intensidade foram elaborados no softwareArcGis $\AA 9$ 9.3, obedecendo-se aos critérios cartográficos. Para isso, utilizou-se a base cartográfica (shapefile) com todos os municípios que foram levantados como local de procedência e 
naturalidade dos casos de Criptococose. Os dados referem-se à tabulação de informações obtidas por meio dos prontuários pesquisados no período de outubro a dezembro de 2014 durante visita às unidades de atendimento.

Os dados de intensidade foram representados nos mapas coropléticos, nos quais as intensidades de procedência e naturalidade e local de atendimento foram representadas por escalas de cores em que as cores mais claras representam os menores registros e as cores mais fortes indicam ocorrência de maiores registros.

\subsection{Aspectos éticos}

A pesquisa cumpriu com todas as exigências éticas contidas nos termos da Resolução do Conselho Nacional de Ética em Pesquisa, foi submetida e aprovada pelo Comitê de Ética em Pesquisa da Fundação de Ensino e Pesquisa em Ciências da Saúde da Secretaria de Saúde do Distrito Federal- FEPECS/ SES-DF, com número do Parecer: 799.605 em 22/09/2014. Houve dispensada assinatura do termo de consentimento livre e esclarecido pelos pacientes envolvidos na pesquisa uma vez que firmou-se $o$ compromisso de mantero anonimato dos sujeitos da pesquisa. 


\section{RESULTADOS}

\subsection{População do estudo}

Foram encontrados 89 registros dos quais após avaliação de duplicidade alcançou-se 88 resultados positivos para Cryptococcus neoformans em pesquisa direta e/ou cultura. Na tentativa de resgate dos 88 prontuários nos Núcleos de Arquivo Médico das unidades hospitalares onde ocorreram os atendimentos foram localizados 87 prontuários, arrolados então na pesquisa.

\subsection{Descrição Epidemiológica}

O estudo do sítio de infecção envolvido na micose mostrou que 86 tiveram diagnóstico de meningoencefalite e 01 paciente o diagnóstico de forma pulmonar. O diagnóstico laboratorial da Criptococose foi feito através de exame direto com tinta da china e cultura de líquidos corporais como líquor, urina e sangue. Todas as amostras foram analisadas pela pesquisa direta e cultura para Cryptococcusspp; e não houve nenhuma amostra analisada pelo método de aglutinação em látex. Das amostras com pesquisa direta para fungo positiva não houve nenhum resultado divergente quanto à cultura para fungo.

Todos os pacientes foram investigados quanto à positividade para o HIV. A sorologia resultou positiva em 63 (72\%) pacientes e negativa em 24 (28\%) pacientes.

Com relação à distribuição etária de forma global, a faixa etária com maior número de pessoas acometidas foi relativa às idades entre 30 a 39 anos (Gráfico1). 
Gráfico 1: Distribuição etária dos 87 pacientes acometidos pela Criptococose

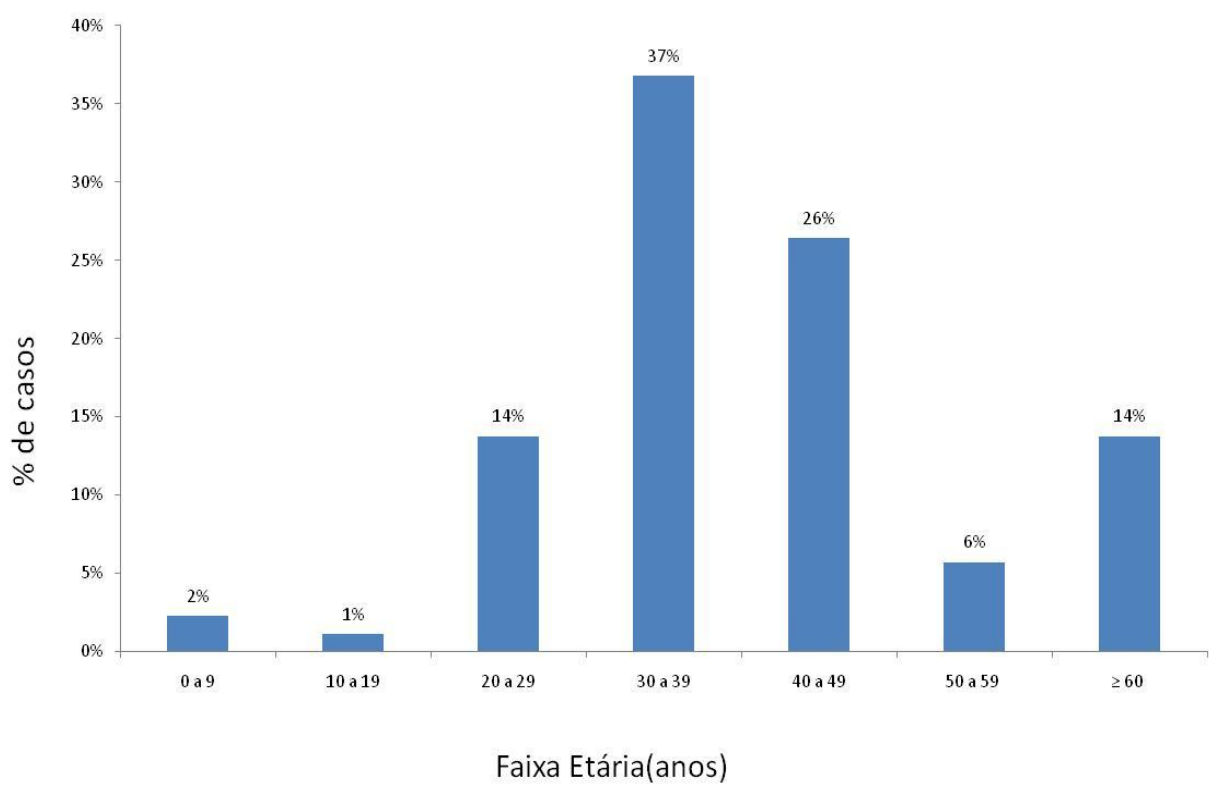

Fonte: Pesquisa Direta, 2014.

$\mathrm{Na}$ análise estratificada por grupos, a proporção de número de casos em pacientes soropositivos para HIV mostrou-se maior na faixa etária de 30 a 39 anos correspondendo a $46 \%$ do universo. Observou-se ainda concentração de casos em indivíduos soropositivos para o HIV em faixas etárias de menores idades do que os soronegativos (Gráfico 2 e 3). 
Gráfico 2: Distribuição etária entre o numero de casos de criptococose e infecção pelo HIV

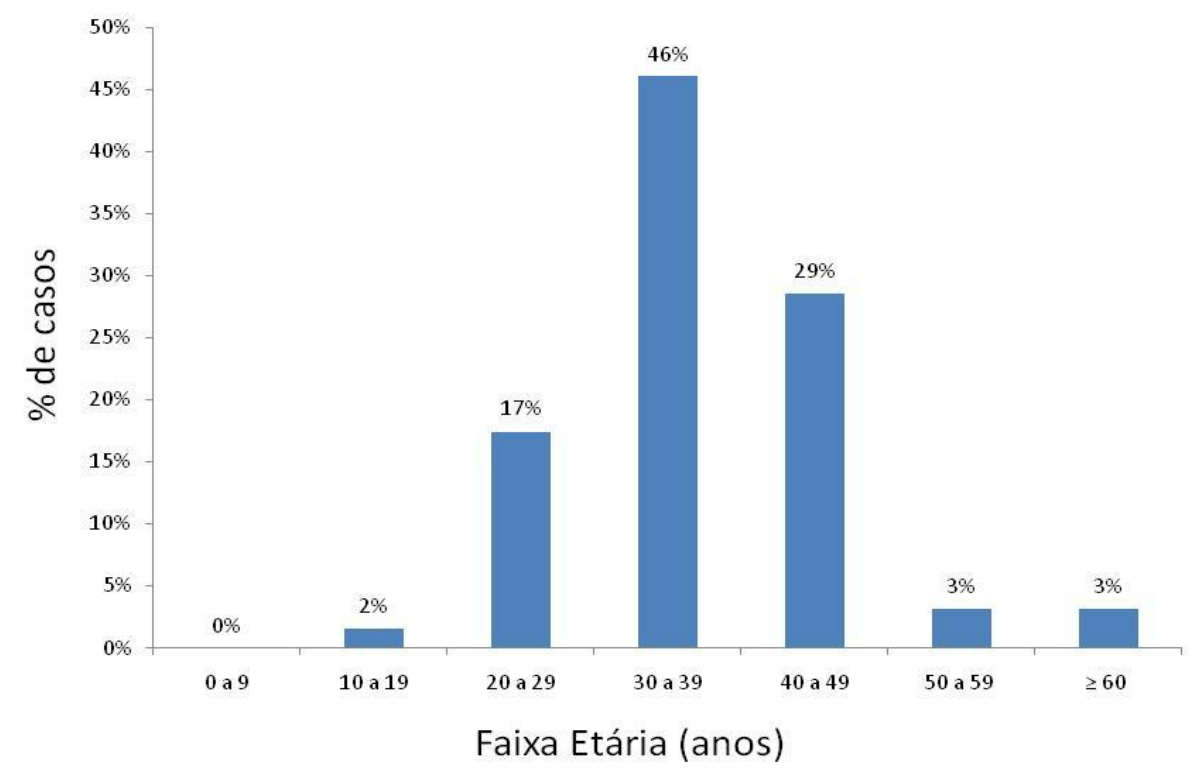

Fonte: Pesquisa Direta, 2014.

Gráfico 3: Distribuição etária entre o número de casos de criptococose sem infecção pelo HIV

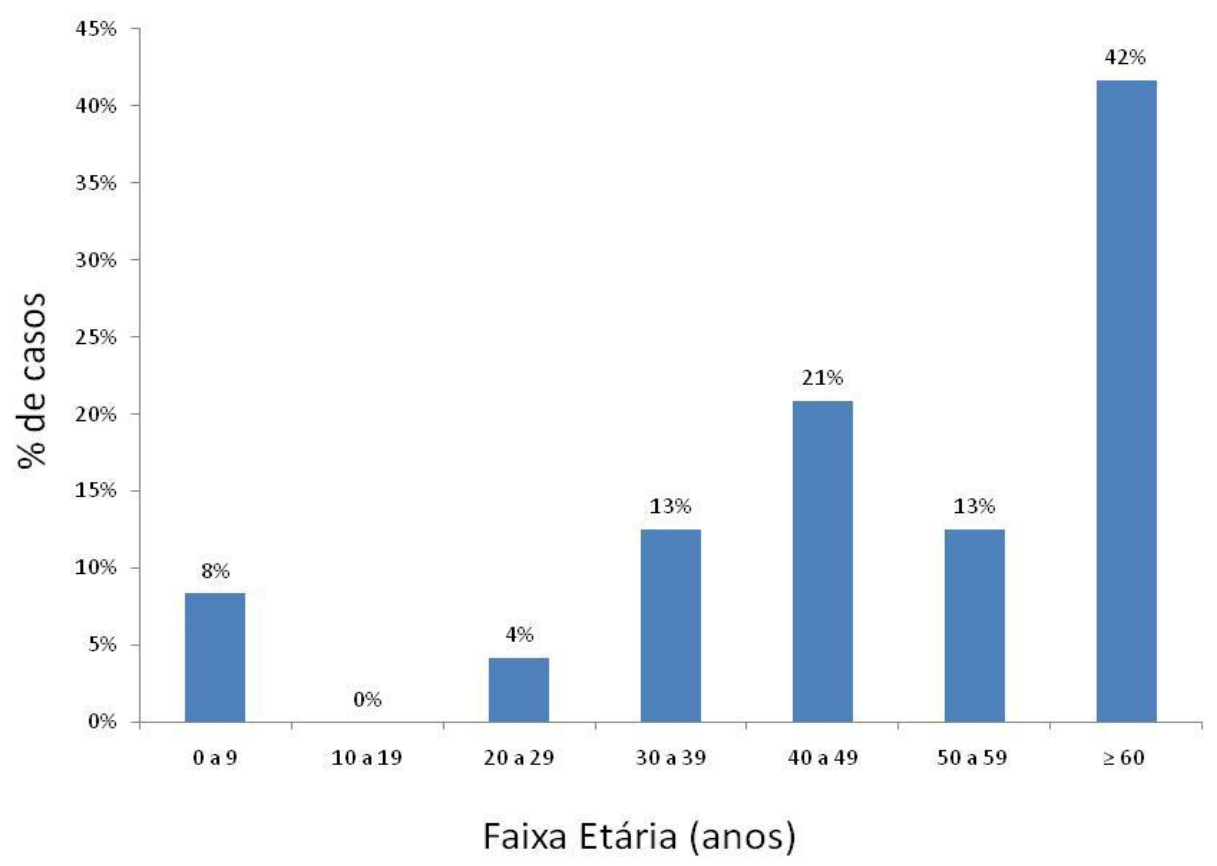

Fonte: Pesquisa Direta, 2014. 
Em relação ao gênero, 56 (64\%) pacientes eram do sexo masculino e 31 (36 \%) do sexo feminino. Observou-se predomínio de casos de Criptococose em homens e ao fragmentar quanto ao status imunológico e soropositividade para o HIV, observou-se que dentre os 31 casos de Criptococose no sexo feminino, 19 (61\%) eram soropositivos para HIV enquanto que dentre os 56 casos de criptococose no sexo masculino, 44 (79\%) eram soropositivos para o HIV demonstrando maior acometimento do sexo masculino pela micose dentre o grupo de soropositivo para o HIV.

Com relação à naturalidade dos casos de Criptococose, o DF e o seu entorno (Goiás) foram às unidades federadas com maior predominância de casos segundo local de nascimento (42) correspondendo a $48 \%$ quando comparados aos demais estados conforme ilustra a Gráfico 4. Os estados da Bahia, Maranhão e Minas Gerais apresentaram respectivamente 10 (11\%), 7 $(8 \%)$ e $7(8 \%)$ da totalidade dos casos.

Gráfico 4: Naturalidade por Unidade Federativa entre os pacientes acometidos com Criptococose

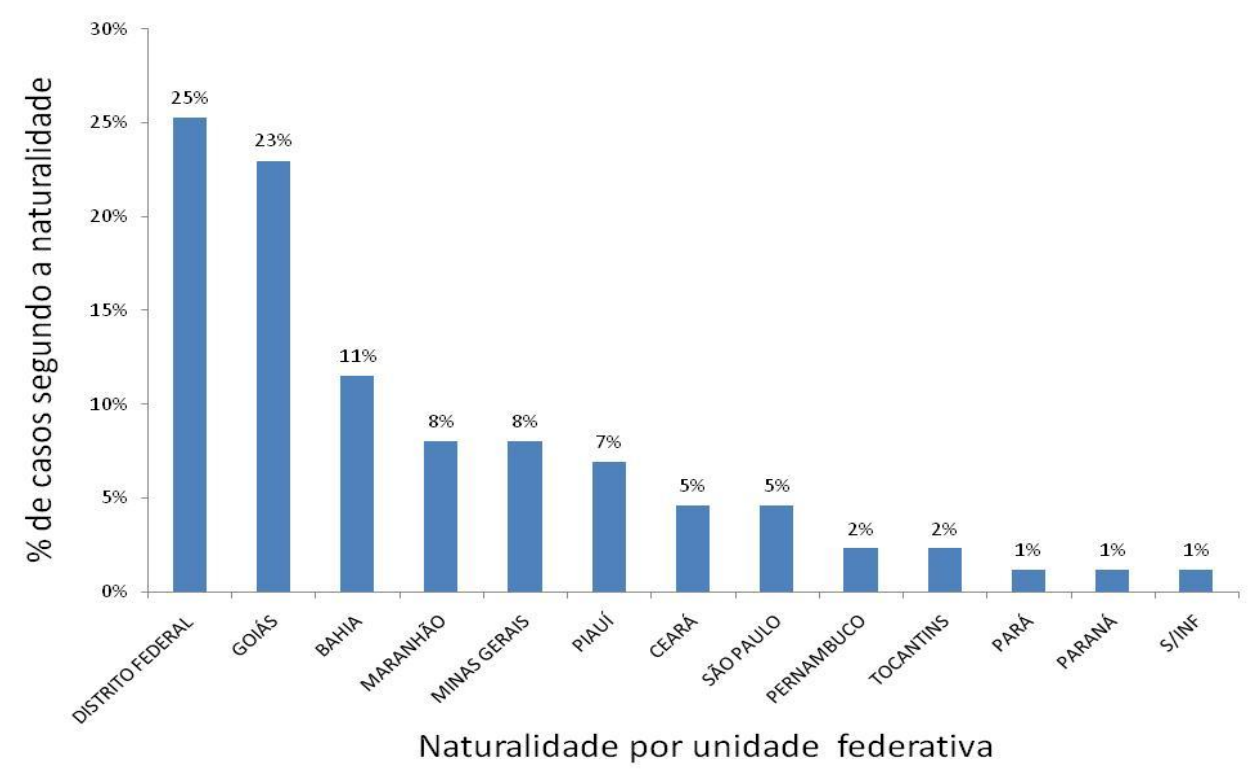

Fonte: Pesquisa Direta, 2014. 
Para ilustração da distribuição dos casos segundo a naturalidade descrita nos prontuários dos pacientes elaborou-se mapa conforme as unidades federadas (Mapa 1).

Mapa 1: Distribuição dos casos segundo naturalidade por unidade federativa.

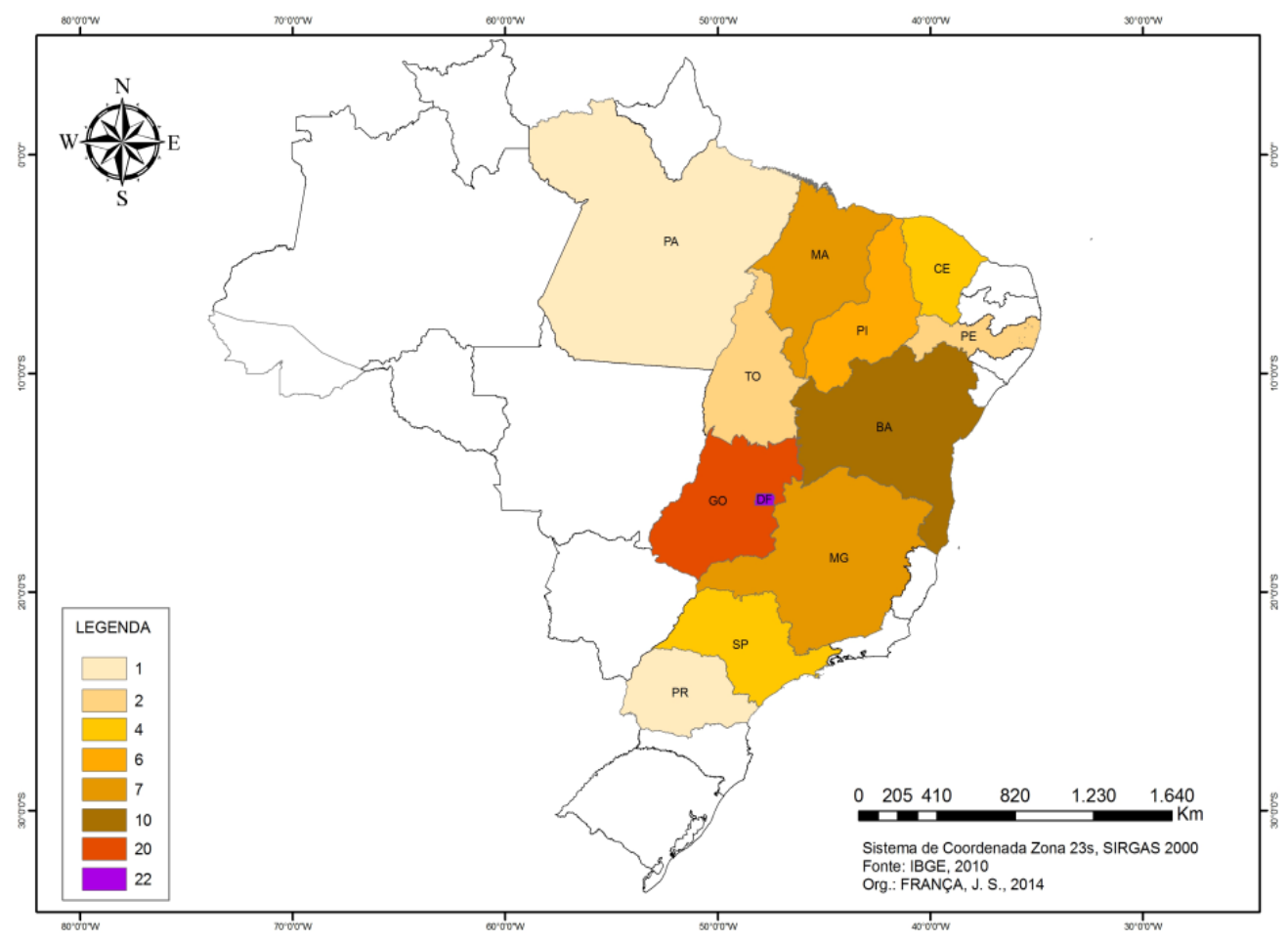

Fonte: Pesquisa Direta, 2014.

Quando se avaliou a procedência dos casos; Ceilândia registrou 15 casos (17\%),seguida por Taguatinga 14 (16\%). Entretanto,observou-se registros em todas as regiões administrativas do Distrito Federal assim como também em municípiosdo entorno (Gráfico 5). 
Gráfico 5: Procedência por Regiões Administrativas entre os 87 pacientes acometidos com criptococose

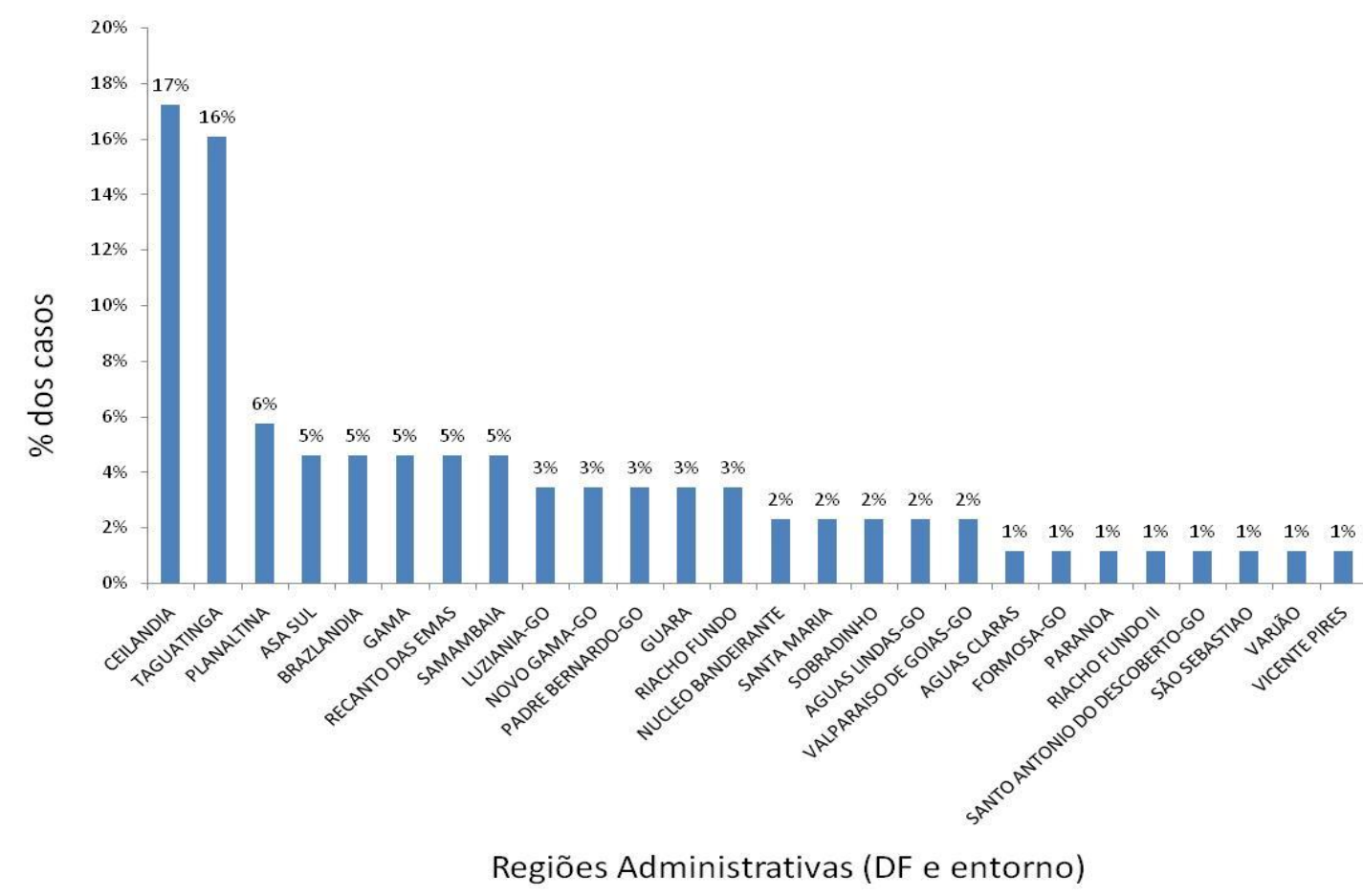

Fonte: Pesquisa Direta, 2014.

Para espacialização dos casos segundo procedência elaborou-se mapa de fluxo conforme ilustra o Mapa 2. 
Mapa 2: Distribuição dos 87 casos de criptococose segundo procedência no Distrito Federal

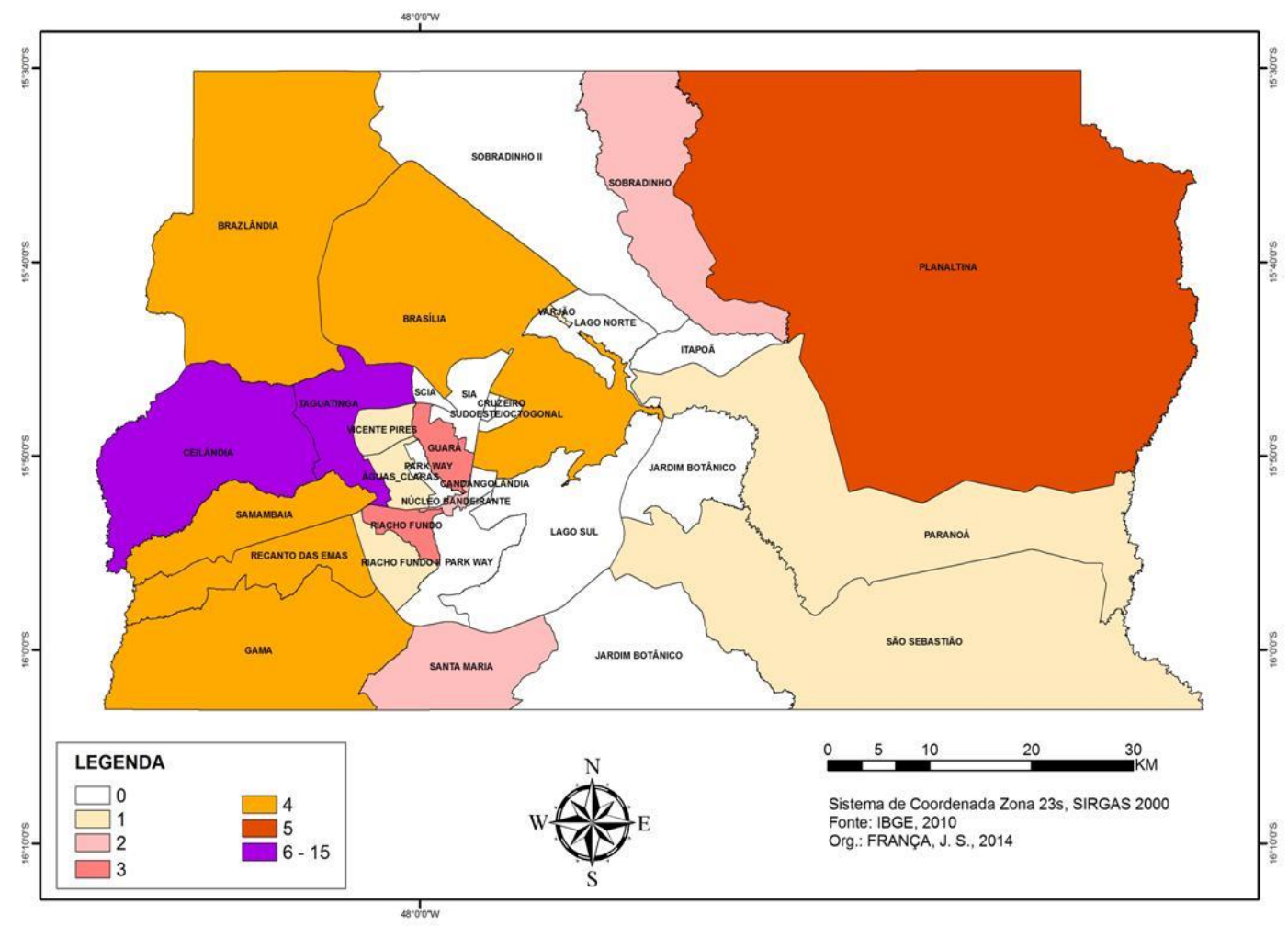

Fonte: Pesquisa Direta, 2014.

As regiões administrativas de Ceilândia e Taguatinga responderam por $34 \%$ da totalidade dos pacientes acometidos pela Criptococose e atendidos na rede pública de saúde. Os mapas 3e 4 ilustram os locais de procura de atendimento pelos casos. 
Mapa 3: Local de atendimento dos casos procedentes da região administrativa de Ceilândia

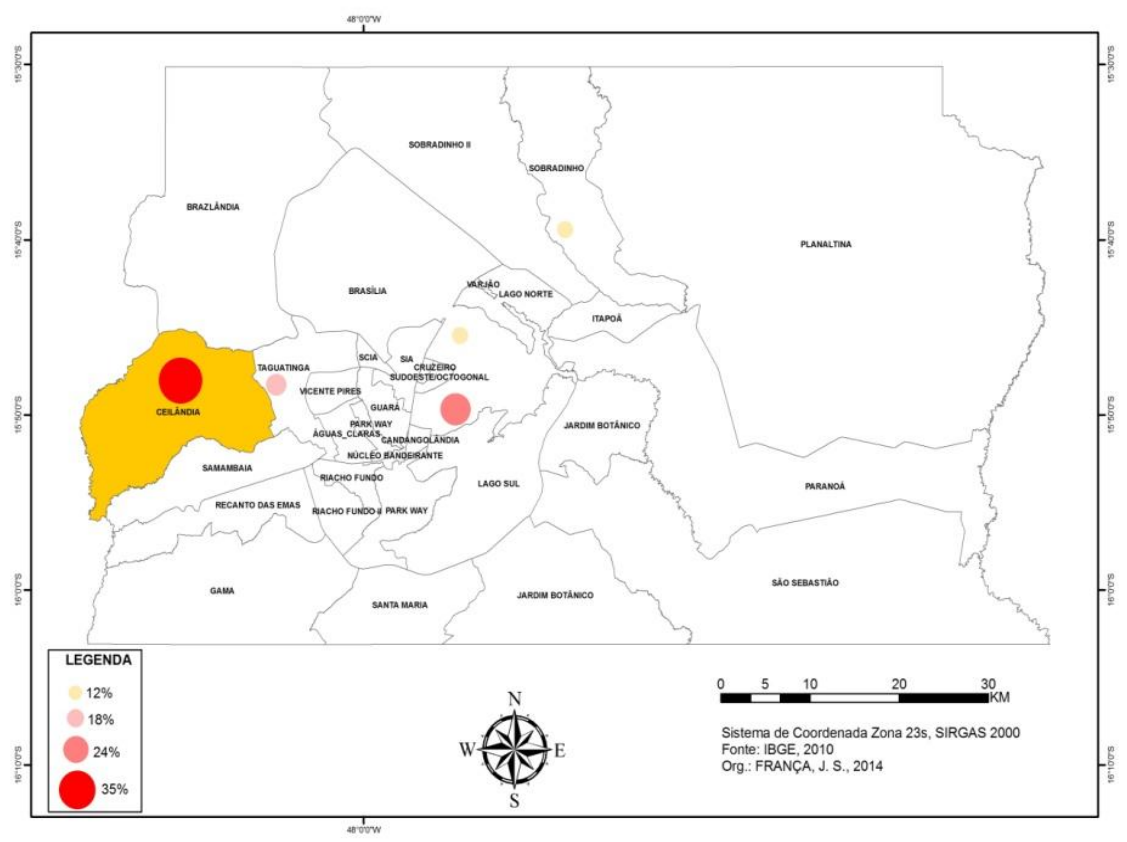

Fonte: Pesquisa Direta, 2014.

Mapa 4: Local de atendimentos dos casos procedentes da região administrativa de Taguatinga

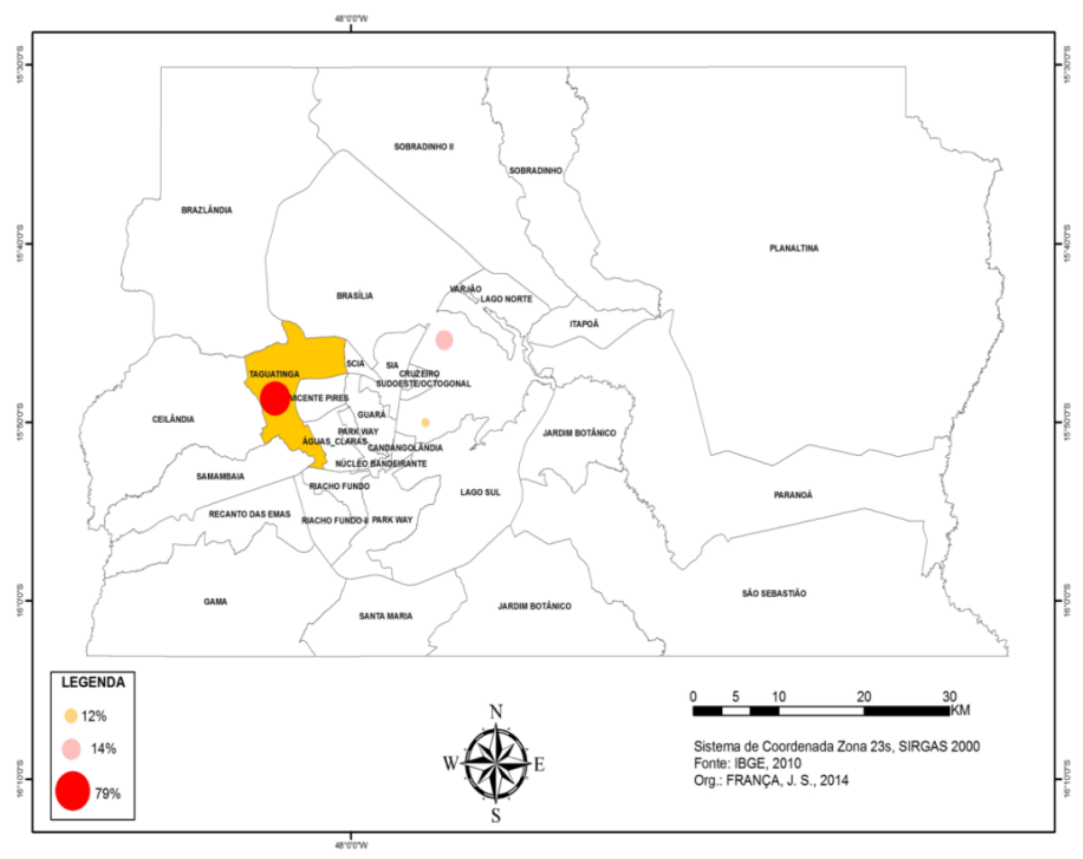

Fonte: Pesquisa Direta, 2014. 
A ilustração dos casos procedentes do entorno do distrito Federal se deu pela execução do mapa 5. Embora a maioria dos casos tenham sido procedentes do próprio Distrito Federal, 15 casos tiveram local de procedência as cidades do entorno.

Mapa 5: Mapa de distribuição dos casos segundo procedência em cidades do Entorno do Distrito Federal

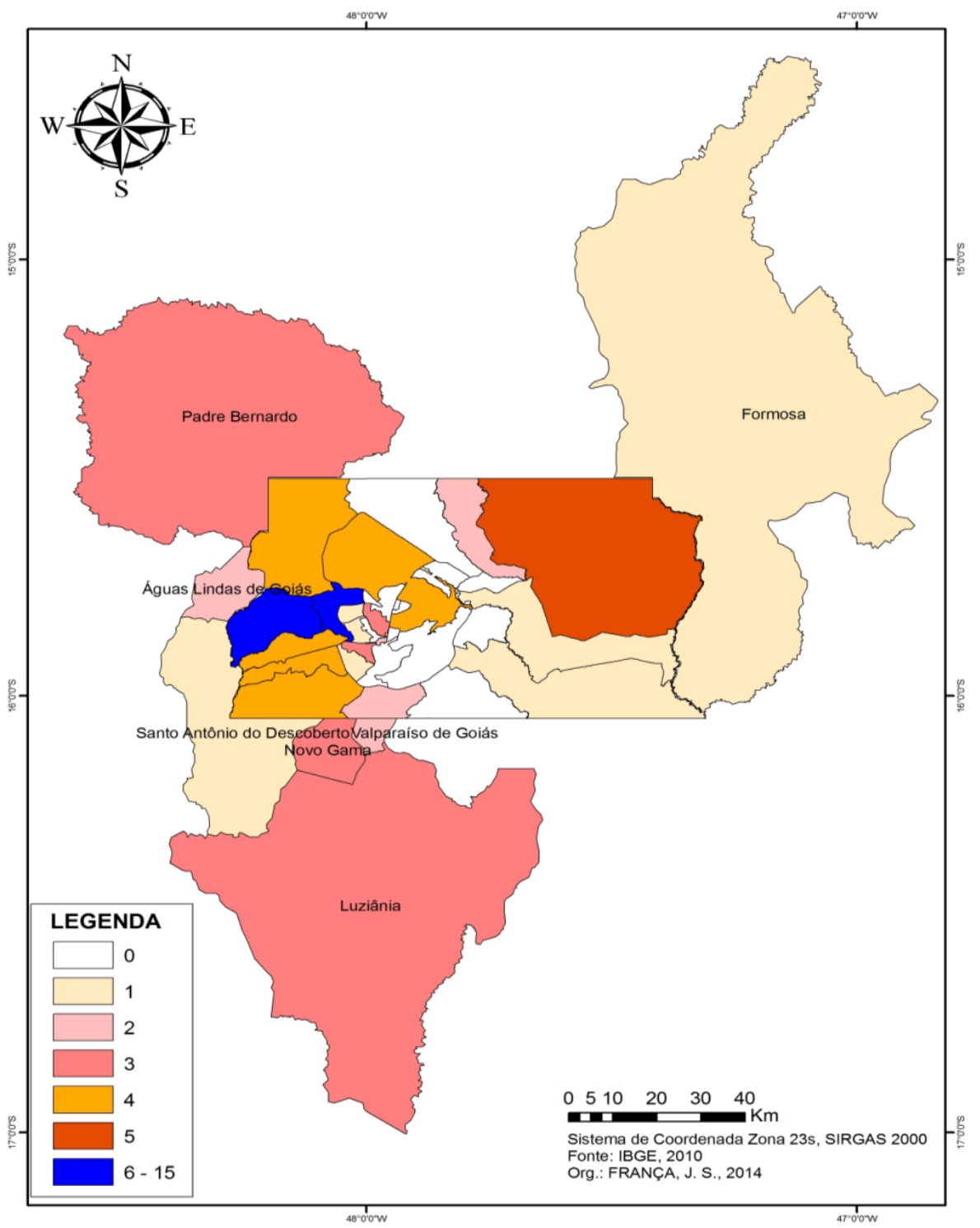

Fonte: Pesquisa Direta, 2014. 
O gráfico 6 ilustra o número de casos segundo local de atendimento. O Hospital de Base do Distrito Federal foi a unidade hospitalar onde houve maior procura pelo atendimento (26\%) seguido pelo Hospital Regional de Taguatinga (22\%) e Hospital Regional da Asa Norte (13\%).

Gráfico 6: Desfecho Clínico segundo unidade de atendimento

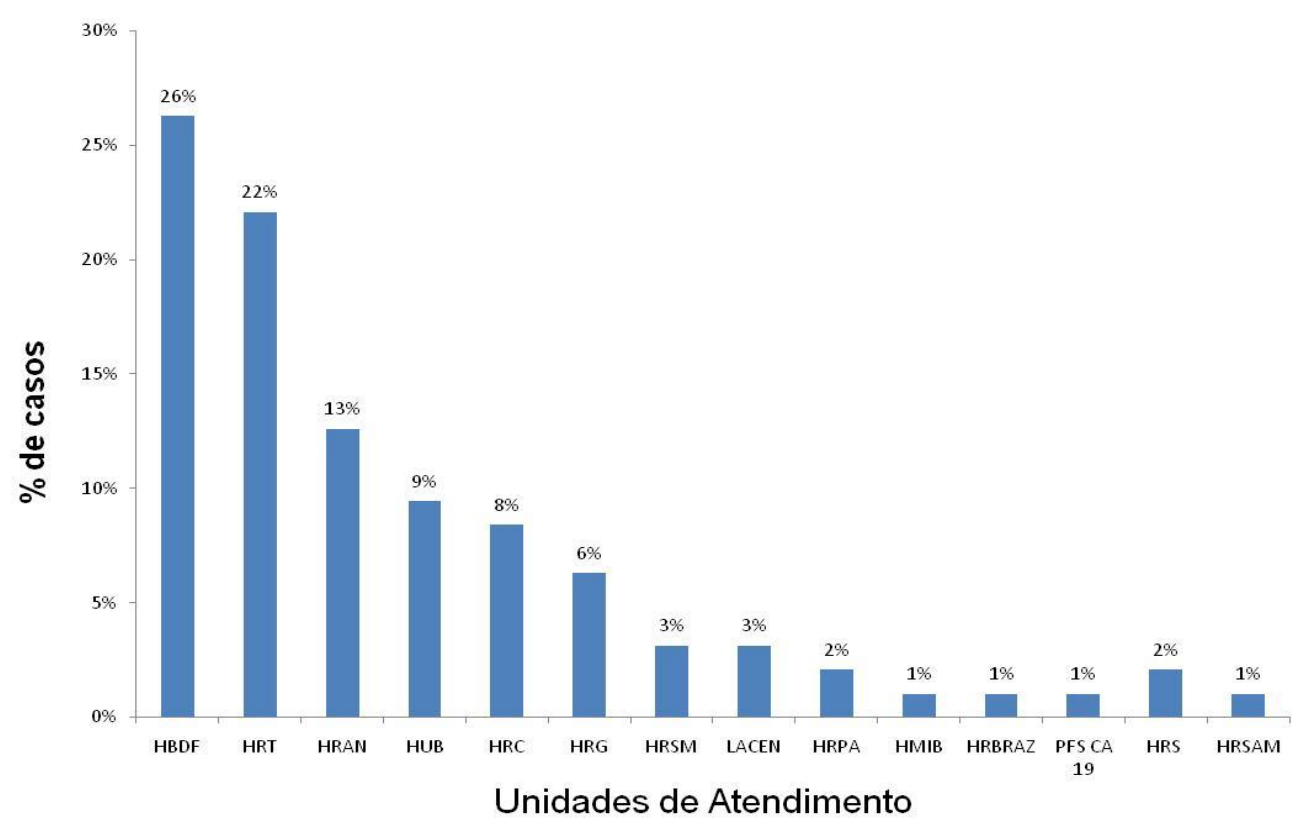

Fonte: Pesquisa Direta, 2014.

Os registros nos prontuários mostraram que, as principais ocupações foram no ramo da construção civil e aposentaria pelo HIV ou pela idade (Gráfico 7). Entre as mulheres a doença acometeu mais as diaristas e donas de casa (com 6 e 4 registros respectivamente). 
Gráfico 7: Ocupações entre os pacientes acometidos pela Criptococose

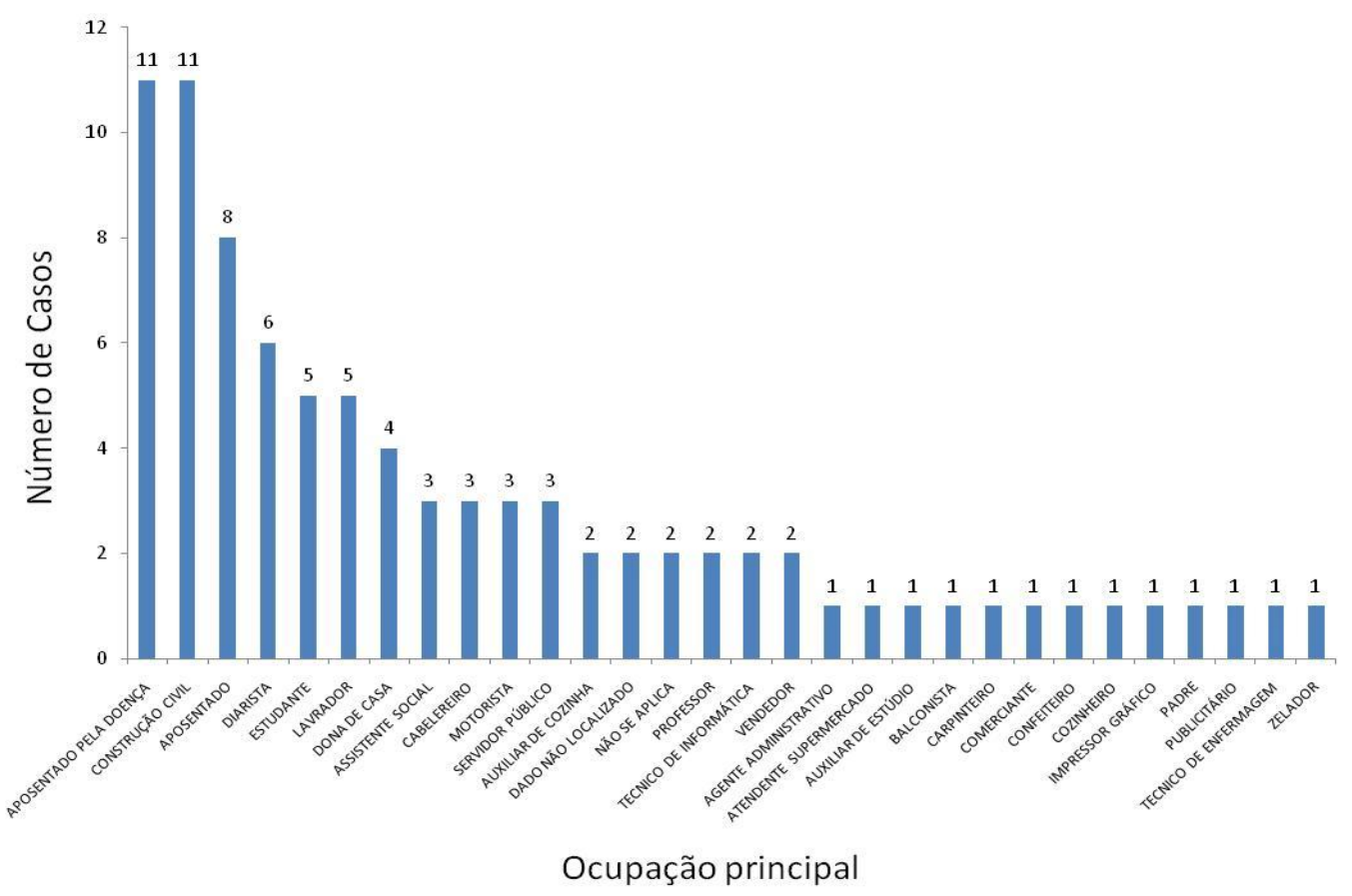

Fonte: Pesquisa Direta, 2014.

Para análise da ocorrência dos casos de Criptococose segundo os anos de diagnóstico e status para o HIV realizou-se gráfico de escala temporal que ilustra a distribuição de frequência de casos de Criptococose segundo ano de diagnóstico e a porcentagem dos casos para cada ano. 
Gráfico 8: Percentual de casos segundo ano de diagnóstico e status sorológico para HIV

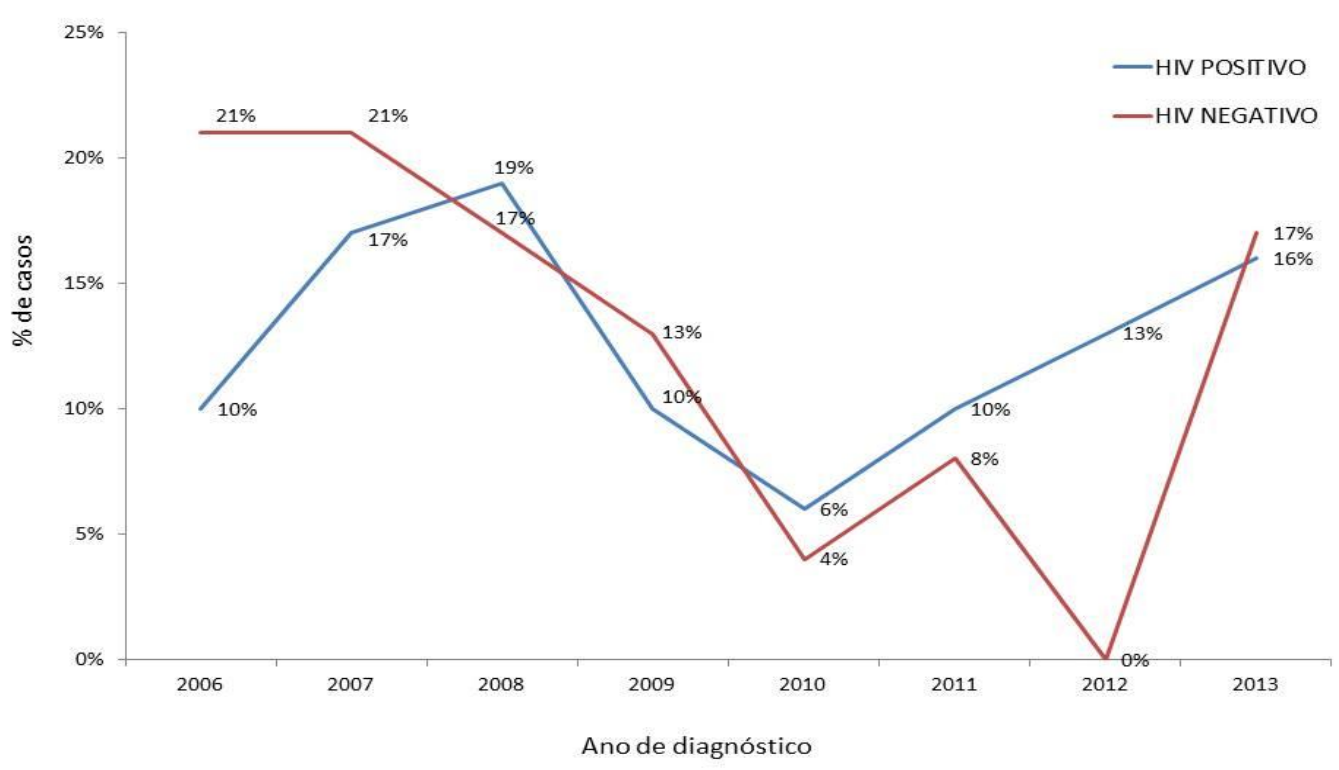

Fonte: Pesquisa Direta, 2014.

A Tabela 7, seguinte, mostra a frequência de alguns sintomas apresentados pelos casos e registrados. É importante ressaltar que 19 pacientes apresentaram síndrome diarreica associada ao quadro e que 12 dos indivíduos acometidos apresentaram alguma queixa visual; dentre estes, dois evoluíram com amaurose. 
Tabela 5: Sinais e sintomas clínicos presentes à admissão dos 87 casos de Criptococose

\begin{tabular}{lll}
\hline Sinais e Sintomas & Número de Relatos & $\%$ \\
\hline Cefaléia & 62 & 71.2 \\
Febre & 60 & 68.9 \\
Vômitos & 51 & 58.6 \\
Convulsão & 27 & 31.0 \\
\hline Desorientação & 44 & 50.5 \\
\hline Tontura & 41 & 47.1 \\
Rigidez de Nuca & 22 & 25.3 \\
Coma & 3 & 3.4 \\
\hline Tosse & 28 & 32.2 \\
Dor Pleurítica & 11 & 12.6 \\
Sudorese & 24 & 27.5 \\
Emagrecimento & 52 & 59.7 \\
\hline Lesões de Pele & 4 & 4.6 \\
\hline Diarréia & 19 & 21.8 \\
\hline Alterações Visuais & 12 & 13.8 \\
\hline Náuseas & 6 & 6.9 \\
Agitação psicomotora & 4 & 4.6 \\
\hline Dispnéia & 7 & 8.0 \\
\hline HIDROCEFALIA & 2 & 2.3 \\
\hline DESMAIO & 2 & 2.3 \\
\hline & & \\
\hline
\end{tabular}

Fonte: Pesquisa Direta, 2014.

O desfecho da infecção dos 87 pacientes que integravam o universo amostral, 41 (47\%) evoluíram com alta hospitalar e 46 (53\%) apresentaram o desfecho clínico óbito.

Com relação à contagem de CD4, 18 pacientes (28,5\%) tinham exames com intervalo inferior a dois meses da admissão os resultados seguem descritos na Tabela 8. Não foi possível correlacionar o quantitativo de carga viral com o desfecho apresentado pelo caso assim como também com a unidade de atendimento. 
Tabela 6: Desfecho clínico dos 18 pacientes com criptococose associada à AIDS e com contagem de CD4

\begin{tabular}{ccccc}
\hline CASO & CD4 & CARGA VIRAL & DESFECHO & UA \\
\hline $\mathbf{1}$ & 45 & $>500000$ & ALTA & HRT \\
$\mathbf{2}$ & 101 & 193774 & ALTA & HRT \\
$\mathbf{3}$ & 180 & $<50000$ & ÓBITO & HRT \\
$\mathbf{4}$ & 477 & $<50000$ & ALTA & HRAN \\
$\mathbf{5}$ & 130 & 96388 & ALTA & HRAN \\
$\mathbf{6}$ & 24 & 20103 & ÓBITO & HRAN \\
$\mathbf{7}$ & 156 & 26914 & ALTA & HRAN \\
$\mathbf{8}$ & 34 & $>200000$ & ÓBITO & HRAN \\
$\mathbf{9}$ & 98 & 9446 & ÓBITO & HUB \\
$\mathbf{1 0}$ & 11 & 47000 & ALTA & HUB \\
$\mathbf{1 1}$ & 5 & 100000 & ALTA & HUB \\
$\mathbf{1 2}$ & 33 & 500000 & ALTA & HUB \\
$\mathbf{1 3}$ & 6 & 100000 & ÓBITO & HUB \\
$\mathbf{1 4}$ & 54 & 3898 & ALTA & HBDF \\
$\mathbf{1 5}$ & 12 & 264 & ÓBITO & HBDF \\
$\mathbf{1 6}$ & 66 & 38010 & ÓBITO & HBDF \\
$\mathbf{1 7}$ & 35 & 110000 & ÓBITO & HBDF \\
$\mathbf{1 8}$ & 133 & 104641 & ALTA & HBDF \\
\hline & & & & \\
\hline
\end{tabular}

Fonte: Pesquisa Direta, 2014.

Comparando-se o desfecho clínico e status imunológico dos pacientes em relação à sua condição sorológica para o HIV, observou-se que $71 \%$ da evolução para alta ocorreram em soronegativos para HIV e $62 \%$ do desfecho óbito ocorreram nos pacientes soropositivos para HIV conforme Gráfico 9. 
Gráfico 9: Desfecho clínico de 87 pacientes com criptococose segundo status imunológico

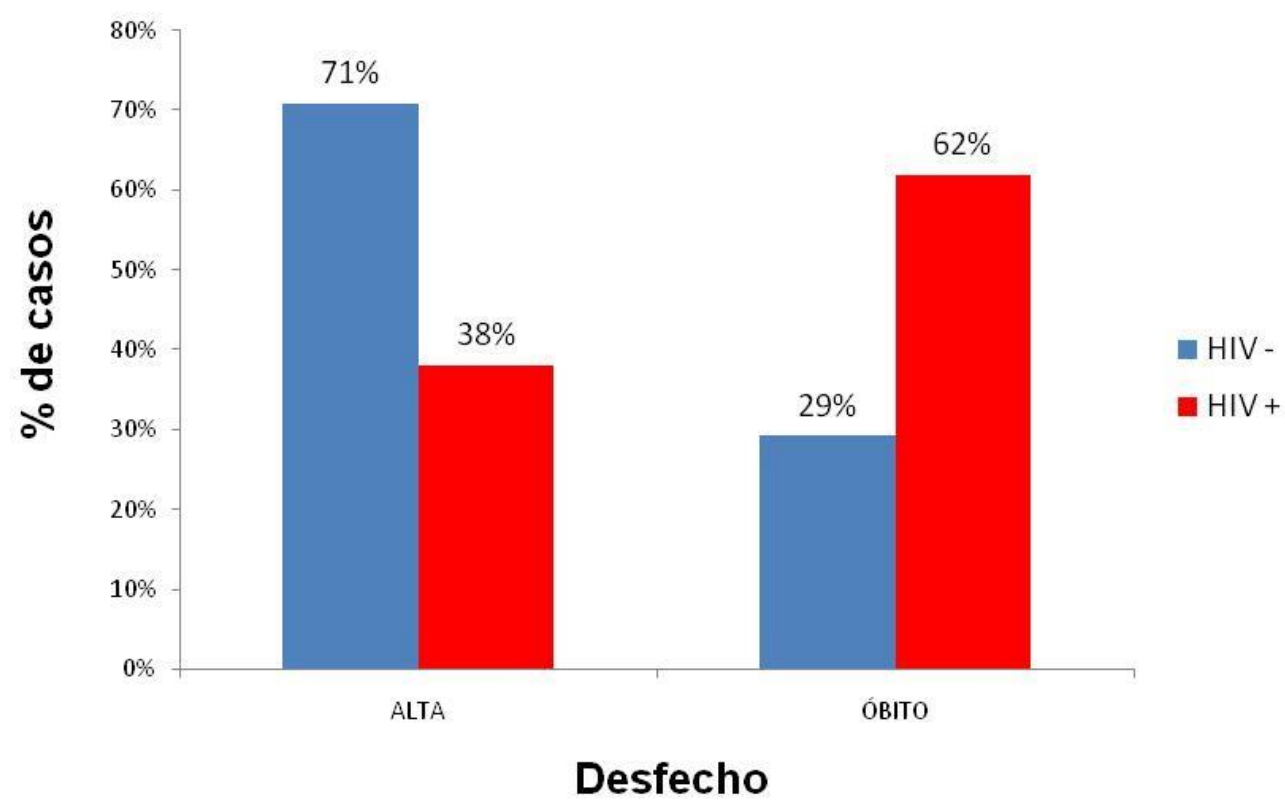

Fonte: Pesquisa Direta, 2014.

Tabela 7: Associação entre sorologia para HIV X sexo X desfecho clínico

\begin{tabular}{ccccc} 
STATUS & \multicolumn{3}{c}{ DESFECHO } & DESFECHO \\
IMUNOLOGICO & SEXO & ALTA & ÓBITO & TOTAL \\
HIV + & MASCULINO & $17(39 \%)$ & $27(61 \%)$ & 44 \\
& & & & $(100 \%))$ \\
\multirow{2}{*}{ HIV - } & FEMININO & $7(37 \%)$ & $12(63 \%)$ & $19(100 \%)$ \\
& MASCULINO & $6(50 \%)$ & $6(50 \%)$ & $12(100 \%)$ \\
TOTAL & FEMININO & $11(92 \%)$ & $1(8 \%)$ & $12(100 \%)$ \\
& GLOBALMASCULINO & $23(41 \%)$ & $33(59 \%)$ & $56(100 \%)$ \\
& GLOBAL FEMININO & $18(58 \%)$ & $13(42 \%)$ & $31(100 \%)$
\end{tabular}

Fonte: Pesquisa Direta, 2014.

Ao realizar a análise do desfecho clínico segundo variável sexo, observou-se que pacientes com criptococose e negativas para o HIV 
apresentaram melhor desfecho clínico com evolução para alta em $92 \%$ dos casos; quando comparada aos pacientes do sexo masculino de mesmo status imunológico que evoluíram para alta em $50 \%$ dos casos (tabela 9 ).

Em pacientes soronegativos do sexo masculino, os desfechos óbito ou alta apresentaram a mesma frequência (50\%) o que não pode ser observado em relação aos soropositivos do mesmo sexo em que o número de casos que evoluíram para óbito mostrou-se significativamente maior $(61 \%$ de óbitos contra $39 \%$ de alta). 


\section{DISCUSSÃO}

A criptococose continua a representar desafio para a prática clínica em decorrência da sua elevada gravidade tanto em hospedeiros imunocompetentes quanto em imunodeprimidos. Para o avanço na melhoria da atenção, há necessidade de se aprimorar o conhecimento epidemiológico e clínico acerca da doença. No DF observou-se que a micose acomete grande proporção de indivíduos que não apresentavam evidencias de fatores predisponentes sabidamente conhecidos como facilitadores de infecções oportunistas, além dos casos em paciente HIV positivos já esperados.

Os casos de meningoencefalite criptocócica não associada ao HIV atribuem-se a condições de imunossupressão como tratamento prolongado com corticosteróides, receptores de órgãos sólidos, doenças malignas como linfomas, sarcoidose entre outros (Sloan \& Parris, 2014). Entretanto a Criptococose pode manifestar-se em indivíduos imunocompetentes, nos estudos de Lee et al., 2010 portadores de diabetes melito, insuficiência renal terminal e cirrose hepática foram os principais fatores de risco para os pacientes sem HIV e $20 \%$ dos pacientes analisados não apresentavam nenhuma doença aparente (Lee et al., 2010). Na casuística de Mezzari et al., 2013 diabetes mellitus (DM) e a tuberculose pleural foram fatores de imunosupressão associados à Criptococose.

Apesar da introdução da HAART, a Criptococose ainda ocupa importante papel entre as infecções oportunistas do SNC em pacientes com AIDS em países desenvolvidos e subdesenvolvidos (MAZUELOS; GARCIA, 2010; Manzardo et al, 2005; Teja et al, 2005) e no Brasil ocupa a terceira posição de infecção oportunista do SNC mais frequente (Ministério da Saúde, 2012). A maior parte dos pacientes neste estudo apresentava sorologia positiva para HIV, configurando-se o $C$. neoformans um importante agente oportunista no nosso meio. 
O quadro clínico mais frequente da criptococose descrito na literatura é a meningoencefalite de caráter subagudo ou crônico (Perfect \& Casadevall, 2002; Singh et al., 2007; Soares et al., 2011). No presente estudo todos os pacientes HIV positivos apresentaram meningoencefalite, observou-se que a neurocriptococose foi à forma predominante, representando $98,8 \%$ dos casos analisados. Achados semelhantes foram relatados por Delgado et al, (2005) em Campinas, Casali et al, (2003) em Porto Alegre; Singh et al. (2007), Perdigão, (2011) em Ceará; Almeida, (2012) em Belém do Pará. A literatura reforça que a apresentação da Criptococose tem algumas diferenças entre pacientes infectados com HIV e os não infectados. Na AIDS os pacientes geralmente apresentam febre e cefaléia, mal estar e vômitos, podendo ocorrer em 7 a $8 \%$ dos pacientes lesões cutâneas, simulando molusco contagioso (Lacaz et al., 2002). Apenas uma pequena porcentagem chega a apresentar sintomas de meningite como pescoço rígido, fotofobia e visão dupla.

Esta pesquisa apontou que a frequência de manifestações clínicas observadas nos pacientes descritos foram semelhantes as encontradas por outros autores, sendo mais proeminentes os sinais e sintomas de meningoencefalite agravada com hipertensão intracraniana. Tais achados também foram encontrados e discutidos por outros autores como Pappalardo e Melhem (2003), Andrade (2006); Pinto Júnior.,(2006); Lindembergetal, (2008); Perdigão (2010); Almeida (2012). Para Chandler et al (2002), estas manifestações clínicas são frequentemente observadas em pacientes com meningite criptocócica. Darzé et al (2000) revisaram 104 prontuários de pacientes com este diagnóstico, e os sinais e sintomas clínicos mais comuns foram cefaléia $(92,7 \%)$, febre $(84,4 \%)$, rigidez de nuca $(83,2 \%)$ e alteração da consciência (43,8\%). Nos estudos de Almeida (2012) a manifestação neurológica mais observada foi a alteração da consciência que se mostrou presente em $40,4 \%$ dos pacientes, de um total de 94 . Para Moretti et al (2008) a meningoencefalite ocorre de modo agudo, e cefaléia e febre estão presentes em $76 \%$ e $65 \%$ respectivamente e alteração da consciência ocorre em $30 \%$ dos pacientes. 
Os métodos diagnósticos utilizados para definição de caso positivo para Cryptococcus basearam-se em sua totalidade na pesquisa direta do fungo em tinta de china e cultura.O teste de aglutinação do látex para antígenos criptocócicos no LCR e soro, que tem sensibilidade de 91 a 100\%, não foi realizado em nenhum dos casos. Na casuística de Darze et al., 2000, com 104 casos o diagnóstico foi realizado através da preparação com tinta da China e cultura em quase sua totalidade com apenas uma deteç̧ão do antígeno criptocócico no LCR pelo teste de aglutinação do látex em 1 caso e pela biópsia de tumoração cerebral em outro.

Em sua quase totalidade, os casos apresentaram procedência do próprio Distrito Federal (82\%) e suas regiões administrativas, $18 \%$ dos casos apontavam procedência de regiões do entorno do Distrito Federal, evidenciando a persistência de tais fluxos populacionais para atendimento na rede hospitalar pública do Distrito Federal. Analisando-se a naturalidade dos casos, $48 \%$ foram deram naturais do Distrito Federal ou cidades do entorno (estado de Goiás) nos demais estados foram apontados a Bahia, Maranhão, Minas Gerais e Piauí como origem dos pacientes. Tendo em vista o longo período de latência da micose e que a região Norte e Nordeste do Brasil são endêmicas para $C$. gatti, é importante na história clínica do paciente o conhecimento acerca da sua procedência. Como há um forte influxo migratório de regiões endêmicas, estudos prospectivos e ambientais devem ser realizados de forma a descobrir se há realmente uma endemia local ou se tratam apenas de casos importados.

A análise epidemiológica revela uma grande discrepância na freqüência de infecções por Cryptococcus em pacientes do gênero masculino e feminino, com homens apresentando maior incidência de infecção quando comparado àsmulheres. Curiosamente, esta diferença de gênero na suscetibilidade de infecções foi observada mesmo antes do começo da epidemia do HIV, em que a incidência de Cn infecção era 2-3: 1. Tanto antes da epidemia do HIV e, recentemente, uma explicação para o aumento da incidência no sexo masculino tem sido a maior exposição aos 
esporos do Cryptococcus. Na Argentina, Bava et al (1993) descreveram 105 casos de Criptococose diagnosticados com maior acometimento do sexo masculino. Nesta casuística a Criptococose prevaleceu em $64 \%$ dos casos no gênero masculino estando de acordo com outros dados encontrados na literatura mundial e brasileira (Chen et al, 2000; Antinori et al, 2009; Mirza et al,2003; Dromer et al, 2004, Millogo et al, 2004, Almeida, 2012, Mezzari et al., 2013). O Ibero American Cryptococcal Study Group, realizado em 9 países - incluindo o Brasil, encontrou uma incidência 5,1 vezes maior em homens do que em mulheres (Meyer et al., 2003). Duppont et al (1992) já admitida em décadas passadas que pacientes do sexo masculino com AIDS apresentam maior risco à Criptococose do que os do sexo feminino, predominando no sexo masculino independentemente da forma clínica.

No presente trabalho, ao estratificar quanto ao status imunológico e a soropositividade para o HIV, o sexo masculino continuou sendo o mais acometido pela micose. Nos estudos de Dromer et al (2004) esta diferença de incidência entre os gêneros varia entre pacientes HIV positivos e negativos onde a proporção homem-mulher com infecção pelo $H I V=6,8$; versus 1.7 entre pacientes soronegativos, o que também foi demonstrado por Chen et al (2000) em quea proporção homem- mulher $=15,4: 1$ entre pacientes com AIDS versus 1,2: 1 entre pacientes sem AIDS; $P<0.001$.

No estudo de Almeida (2012) analisando a razão de chance que os homens apresentaram em relação às mulheres de contraírem a neurocriptococose que os homens apresentaram aproximadamente 1,4 vezes mais chances de contrair a neurocriptococose do que as mulheres (O.R= 1,3529; IC 95\%= 0.45-3,52).

Vários estudos relatam maior prevalência de Criptococose em homens, apesar de não existir explicação biológica para tal observação (CASADEVALL et al, 1998), acredita-se que a razão para esta diferença tem caráter multifatorial, uma vez que, a criptococose acompanha a distribuição de sexos da infecção pelo HIV, com marcado comportamento de risco para o contato com o patógeno na população masculina. Para Mitchel \& Perfect 
(1995) no início da epidemia de AIDS, o número de casos de Criptococose no gênero masculino chegava a ser oito vezes superior ao encontrado no gênero feminino, acompanhando o perfil da infecção pelo HIV. Atualmente, observa-se mudança de comportamento da infecção pelo HIV na população feminina, sendo descrito por Moreira et al (2006) como femininização da epidemia de AIDS no século XXI, o que possivelmente resultará em mudança na distribuição entre os sexos.

No presente estudo, a distribuição dos casos por faixa etária mostrou que $69 \%$ dos casos situava-se entre os 30 e 59 anos, sendo a faixa etária mais acometida dos 30 aos 39 anos, correspondendo a 32 (37\%) dos pacientes, caracterizando um grupo de adulto jovem sujeito a Criptococose. Este achado tem relação com a maior prevalência de AIDSD na faixa etária de 25 a 49 anos, em ambos os sexos, segundo dados do Ministério da Saúde.

A maior prevalência de criptococose na faixa etária entre os 30 e 59 anos tem sido relatada na literatura. Os estudos de Mezzari et al (2013) analisou 42 prontuários de pacientes, em sua maioria, do sexo masculino, com idade entre 30 e 49 anos e com principal fator de imunodepressão a SIDA. Corroborando com este achado, o estudo de Andrade (2006) realizado no Instituto de Infectologia Emílio Ribas com 34 pacientes soropositivos para o HIV,encontrou média de 35,4 anos. Segundo o estudo de Leal et al (2008), realizado com pacientes apresentando meningite criptocócica no Rio Grande do Sul, a média de idade dos pacientes analisados foi de 36,36 anos, sendo a faixa mais acometida entre 30 e 39 anos $(46,24 \%)$. Casali et al (2003) e Meyer et al (2003) relataram em seus estudos que a distribuição etária dos pacientes com Criptococose estava entre 35-40 anos. Estes resultado foram similares aos de outros estudos realizados na África por Millogo et al (2004) com média de idade de 34,25 anos, na França por Dromer et al (2004) com média de 33 anos para mulheres e 36 para homens e na Austrália com média de 36,8 anos para homens e 47,7 para mulheres segundo casuística de Jenney et al., (2004). Nossos achados corroboram com a literatura mundial quando Tintelnot et al 
(2003) descrevem que homens foram acometidos por criptococose numa faixa etária de 31 a 40 anos em sua maioria nas regiões da Áustria, Alemanha e Suíça; enquanto entre as mulheres a faixa etária esteve entre 21 a 30 anos. Observa-se que a faixa etária mais acometida em ambos o sexo tem sido aquela em que os indivíduos estão no ápice de sua contribuição socioeconômica, por suas atividades profissionais o que levanta as importantes repercussões da criptococose na dinâmica populacional e no comprometimento das atividades ocupacionais dos pacientes acometidos por esta micose.

$\mathrm{Na}$ presente análise observou-se maior proporção de casos de criptococose em pacientes com AIDS em faixas etárias menores do que os não AIDS. A predominância de criptococose em adultos jovens obedece a razões semelhantes à distribuição entre sexos. É na terceira e quarta décadas de vida em que predominam os diagnósticos de soropositividade para o HIV, bem como as épocas em que se manifesta a imunossupressão com maior freqüência, fato ressaltado por outros estudos epidemiológicos. É importante mencionar o estudo de Meyer et al (2003), em que é relatado que pacientes HIV positivos homens possuem incidência de 5.5 vezes maior de acometimento do que mulheres. No estudo de Dromer et al (2004) foi demonstrado diferença de idade entre pacientes com Criptococose com e sem AIDS. Neste estudo, entre os soropositivos para o HIV, foi descrito uma média de idade menor (36 anos) quando comparados aos soronegativos (52 anos).

Neste estudo, 2\% dos pacientes estavam na faixa etária abaixo de 10 anos sem correlação com status sorológico positivo para HIV. A literatura internacional refere que a Criptococose na infância é rara e que a freqüência da doença criptocócica entre crianças infectadas pelo HIV é muito menor do que entre pacientes adultos (Chen et al,2000). Estudo com crianças americanas com AIDS observou prevalência de 1,4\% de infecção criptocóccica, no período de 1985 a 1996 (Abadiet al,1999). Para Batista et al (2005), $70 \%$ dos casos de Criptococose ocorrem em homens adultos, com idade entre 30 a 60 anos, mostrando-se rara no grupo pediátrico. 
$\mathrm{Na}$ análise de Goldman e colaboradores (2001), que avaliou soro de 185 crianças de Bronx, em Nova Yorque, para determinar se a baixa prevalência de doença criptocóccica na infância devia-se a pouca exposição ao Cryptococcus, observaram que a idade de soroconversão para a maioria delas era inferior a 10 anos. Concluíram queos resultados sugerem que a baixa incidência de Criptococose em crianças com AIDS não se deveria à falta de exposição ao agente.

No Brasil, a meningite criptocóccica em crianças está bem descrita na região Nordeste, onde C. gattii é endêmico. Nos estudos de Martins (2003) que envolveram a análise de 53 casos com idade inferior a 14 anos; Corrêa (1999) com 19 casos menores de 13 anos e Cavalcanti (1997) com 17 casos com idade inferior a 10 anos todos os autores não constataram nenhum caso de AIDS e observaram significativo predomínio do isolamento de $C$. gattii. No nosso estudo, em decorrência da limitação do laboratório de micologia do LACEN-DF que identifica somente o fungo até o seu gênero, é provável que esses casos se devam realmente à doença causada por $\mathrm{C}$. gatti.

Com relação à contagem de CD4 em 28,5\% dos casos levantados foi possível encontrar registros da carga de linfócito TCD4 com tempo inferior a dois meses e observou-se predominância de imunodepressão. A média de células TCD4 foi de 88,8 células $/ \mathrm{mm} 3$, e apenas 02 pacientes apresentaram medida superior a 100 células $/ \mathrm{mm}$, coincidindo com o demonstrado no estudo de Andrade (2006), Dromer et al (2004), Mussini et al (2004), Vibhangool et al (2003), Antinori et al (2001). As baixas contagens de linfócitos TCD4 demonstram o nível de imunossupressão dos pacientes que desenvolvem a Criptococose. A linfometria CD4 é importante parâmetro para determinação do estado imunológico do paciente infectado pelo HIV, sendo útil, pois, para determinação do prognóstico, podendo predizer também quais as entidades oportunistas em que o paciente se encontra sob risco. Todavia este exame por inúmeras vezes não está disponível como rotina e a presença deste dado laboratorial não foi uniformemente encontrado em todos os prontuários. Gonzalez (1999) afirma que a 
neurocriptococose está relacionada a depleção dos linfócitos $\mathrm{T}$, bem como aparece quando os linfócitos TCD4 estão abaixo de 100 células/ mm3. Lane et al (1994) cita que as infecções oportunísticas mais sérias ocorrem quando o paciente apresenta, no sangue periférico, contagem de linfócitos TCD4 inferior a 200 células/ mm3, sendo necessário empregar antifúngico profilático.

Quando realizada a análise por períodos, percebeu-se oscilação no número de resultados positivos para a micose nos últimos anos. Os resultados referem-se às amostras enviadas e analisadas pelo Serviço de Micologia do Laboratório Central de Brasília o que não descarta a possibilidade de espécimes clínicos terem sido enviados a outros serviços laboratoriais o que impediu o conhecimento e acesso aos resultados.

Quanto à análise da ocupação laboral dos casos, as profissões encontradas, neste estudo, foram muito discrepantes e não permitiram realizar correlações entre a atividade profissional desenvolvida e a Criptococose. Considerando que parte dos casos possuía status sorológico positivo para o HIV, as informações de ocupação contidas nos prontuários referiam em sua maioria ao usufruto de aposentadoria pela doença não sendo possível determinar aocupação laboral anterior ao diagnóstico do HIV. Ao estratificar por gênero observou-se que construção civil foi o segmento de trabalho freqüentemente descrito para os casos do sexo masculino e as atividades domésticas foram freqüentemente encontradas em mulheres infectadas por criptococcus spp. O resultado da pesquisa com relação à infecção por cryptococcus no sexo feminino pode ser conseqüência do fato de a atividade doméstica ser a ocupação freqüente entre as mulheres acometidas pelo HIV.

No estudo de Almeida (2012), a profissão mais freqüente entre os homens foi a de pedreiro $(10,6 \%)$ sendo que a mesma freqüência da doença foi encontrada de desempregados (10,6\%). Entre pacientes do sexo feminino as principais profissões referidas foram donas de casa $(20,2 \%)$ e empregadas domésticas (17\%) havendo relatos de aposentadorias, diarista, empreiteiro civil, garçom e pescador (todos com 1\%). 
No presente estudo, observou-se que $72 \%$ dos pacientes com criptococose eram infectados pelo HIV. No Brasil, Livramento e colaboradores (1992) em São Paulo, no período de 1984 a 1992, referem que a AIDS era a doença de base em $63 \%$ dos pacientes com meningite criptocócica e Carvalho (2003), em Ribeirão Preto, entre 1980 e 2000, observou que $73,1 \%$ dos pacientes com Criptococose eram infectados pelo HIV. Na série de Rozenbaum e Gonçalves (1994) no Estado do Rio de Janeiro, de 1960 a 1989, 52,7\% dos casos tinham AIDS.

No estudo de Nishikawa et al (2003), a infecção por $C$. neoformans estava associada com AIDS nas regiões sudeste $(98,3 \%$ dos casos contra $1,7 \%$ de $C$. gattii) e nordeste $(87,5 \%$ dos casos contra $12,5 \%$ de $C$. gattii); dentre os pacientes HIV negativos, o $C$. neoformans foi o agente da Criptococose em $53 \%$ dos casos no sudeste e $9,7 \%$ no nordeste e o $C$. gattii foi o agente em $47 \%$ dos pacientes no sudeste e $90,3 \%$ nordeste. Para a presente análise, a evolução letal no grupo de pacientes com AIDS deve ser considerada elevada (61,9\%) quanto comparada aos indivíduos soronegativos (29,1\%). Ao estratificar quanto ao gênero observou-se que em pacientes soropositivos do sexo masculino a letalidade permaneceu elevada letalidade $(61,4 \%)$ enquanto que em indivíduos masculinos soronegativos a razão entre o número de óbitos e os casos existentes mostrou-se $50 \%$. Na população feminina foi observada uma letalidade de $63 \%$ nos casos de soropositividadepara o HIV e $8,3 \%$ em soronegativas.

No geral, pacientes que convivem com HIV apresentam taxas de letalidade mais elevadas por meningite criptocócica quando comparados aos pacientes soronegativos. A letalidade associada à Criptococose em pacientes HIV positivos varia de $22,2 \%$ a $76,9 \%$ na literatura existente (Rozenbaum \& Gonçalves, 1994; Cavalcanti, 1997; Millogo et al, 2004; Jenney et al,2004; Mezzani et al,2013).

Uma recente publicação apontou que dos 957.900 casos de criptococose estimados com envolvimento das meninges, 624.700 mortes ocorrem no mundo todo a cada ano devido à Criptococose, sendo esta a principal causa de morte de 30 a 60\% dos casos (Voelz \&May, 2010). 
Estudo realizado na República Central Africana, a mortalidade hospitalar foi $16,7 \%$ para os pacientes de HIV negativas e $57 \%$ para os pacientes que vivem com HIV (Bekondiet al,2006). Os trabalhos de Darzé et al (2000), na cidade de Salvador (Bahia) acusaram uma letalidade de $42,7 \%$.

Este é o primeiro estudo que descreveu as características da criptococose em pacientes com e sem HIV no Distrito Federal, contudo o estudo apresenta algumas limitações metodológicas. O delineamento metodológico utilizado para a realização deste estudo foi descrição de uma série de casos, portanto um estudo retrospectivo realizado a partir da revisão de prontuários médicos, instrumentos desenvolvidos com o objetivo de registrar assistência prestada e dar continuidade ao atendimento dos pacientes e não exclusivamente para fins de pesquisa científica. Para levantamento dos casos o ponto de partida foram os resultados positivos de amostras enviadas ao LACEN-DF após atendimento dos pacientes nas unidades hospitalares públicas do Distrito Federal, assim utilizou-se relatórios junto o serviço de micologia. Tal estratégia possivelmente limitou 0 conhecimento de possíveis casos atendidos em outras unidades hospitalares ou que por questões diversas não tiveram suas amostras enviadas ao LACEN. Este estudo permitiu conhecer os casos de criptococose sem possibilidade de diferenciar a espécie de cryptococcus devido às limitações do serviço de laboratório na identificação do patógeno.

O presente estudo evidenciou que parte significativa dos casos analisados corresponde a critpcocose primária não associada ao HIV e que novos estudos devem ser executados de se identificar em nível de espécie e tipo molecular o agente e uma possível endemia desta espécie. 


\section{CONCLUSÃO}

- O perfil clínico, epidemiológico e laboratorial dos pacientes com Criptococose atendidos nas unidades hospitalares da rede pública do Distrito Federal demonstra padrões semelhantes aos encontrados na literatura, com acometimento mais freqüente do sexo masculino tanto em indivíduos com status imunológico para HIV positivo ou negativo.

- Nos últimos 7 anos a forma clínica predominante foi a neurocriptococose;

- A AIDS apresentou relevância como doença preexistente e a comparação entre o grupo de pacientes com criptococose e AIDS e o grupo de pacientes com a micose sem AIDS mostrou-se diferente quanto à frequência de acometimento e desfecho clínico com alta letalidade entre os pacientes soropositivos para o HIV e soronegativos; assim sendo, é plausível concluir que as infecções fúngicas sistêmicas representaram importante causa de infecção oportunista e morte entre os pacientes com HIV/AIDS bem como naqueles sem fatores predisponentes evidentes, no DF. 


\section{REFERÊNCIAS BIBLIOGRÁFICAS}

Abadi, J.; Nachman, S.; Kressel, A.B. Cryptococcosis in children with AIDS.ClinInfectDis1999; 28(2): 309-313

Almeida, Jairo Cunha de. Perfil clínico-epidemiológico da Criptococose em pacientes HIV positivos atendidos em uma unidade de referência em Belém do Pará. 2012. 77 f. Dissertaçãode Mestrado - Universidade Federal do Pará, Núcleo de Medicina Tropical, Belém, 2012.

Andrade, J.M.P. Hipertensão intracraniana na meningoencefalite criptocócica em pacientes soropositivos para o vírus da imunodeficiência humana: estudo de uma série de casos. São Paulo, 2006. Dissertação de MestradoCoordenação Universidade de São Paulo, Faculdade de Medicina. 2006.

Antinori, S. Ridolfo, A.L, Fasan, M., et al. AIDS associated cryptococcosis: a comparison of epidemiology, clinical features and outcome in the pré-and post- HAART eras. Experience of a single centre in Italy.HIV Medicine. 2009; 10 (1): 6-11.

Araújo, I.B.; Brito, C.R.; Urbano, I.A.; Dominici, V.A.; Silva Filho, M.A.; Silveira, W.L.; Damasceno, B.P.; Medeiros, A.C.; Egito, E.S. Similarity between the in vitro activity and toxicity of two different fungizone/lipofundin admixtures. Acta Cir. Brás.; v. 20, p. 129-133, 2005.

Barchiesi, F.; Cogliati, M., Esposto,M.C.; Spreghini, E.; Schimizzi, A.M.; Wickes, B.L.; Scalise,G.; Viviani, M.A. Comparative analysis of pathogenicity of Cryptococcus neoformans serotypes $A, D$ and $A D$ in murine cryptococcosis. J. Infect., London, v.51, n.1, p.10-16, Jan 2005

Baroni, F.D.E.A.; Paula, C.R.; Silva, E.G.; Viani, F.C.; Rivera, I.N., Oliveira, M.T.; Gambale,W. Crytococcus neoformans strains isolated from church towers in Rio de Janeiro City, RJ, Brazil. Rev. Inst. Med. Trop. São Paulo, v. 482, p. 71-75, 2006.

Batista, L.; Silva, M.V. Criptococose In: VERONESI: Tratado de Infectologia. 3 a Ed. São Paulo: Ateneu, 2005. P.1403-1408.

Bava, A.J. et al. Características epidemiológicas de 105 casos de criptococosis diagnosticados em La Republica Argentina entre 1981- 1990. Revista do Instituto de Medicina Tropical de São Paulo. V. 34. P. 335-340, 1993

Bekondi C, Bernede C, Passone N, Minssart P, Kamalo C, Mbolidi D, et al. Primary and opportunistic pathogens associated with meningitis in adults in 
Bangui, Central African Republic, in relation to human immunodeficiency virus serostatus. Int J Infect Dis. 2006;10(5):38795.

Bivanco FC, Machado CAS, Martins EL. Criptococose Cutanea. Arq Med ABC. 2006;31 (2): 102-109.

Bose, I., Reese,A.J., Ory,J.J., Janbon, G. Doering, T.L.A yeast under cover: the capsule of Cryptococcus neoformans.Eukaryot. Cell 2: 655-663,2003

Brasil. Ministério da Saúde. Secretaria de Vigilância em Saúde. Departamento de Vigilância Epidemiológica, Coordenação geral de doenças transmissíveis, unidade de vigilância das doenças de transmissão respiratória e imunopreveníveis. Vigilância e Epidemiológica da Criptococose. Brasilia-DF, 2012

Byrnes, E.J. et al. Emergence and pathogenicity of highly virulent Cryptococcus gattii genotypes in the northwest United States. Plos Pathog, v. 6, n.4, p. e1000850,apr 2010.

Carvalho, F.S. Estudo comparativo da Criptococose em pacientes aparentemente imunocompetentes, com SIDA ou com outras formas de imunodeficiência. São Paulo. 2003. Dissertação de Mestrado - Universidade de São Paulo/Ribeirão Preto)

Casali, A.K.; Goulart, L.; Rosa E Silva, L.K.; Ribeiro, A.M.; Amaral,A.A.; Alves, S.H.; Schrank, A.; Meyer, W.; Vainstein, M.H. Molecular typing of clinical and environmental Cryptococcus neoformans isolates in the Brazilian state of Rio Grande do Sul. FEMS Yeast Res., V. 3, P. 405-415,2003.

Casadevall, A.; Perfect, J.R. Superoxide dismutase influences the virulence of Cryptococcus neoformans by affecting growth within macrophages. Infect. Immun., v. 71, p. 173-180, 2003.

Casadevall. A.; Steenbergen, J.N.; Nosanchuk, J.D. "Ready made" virulence and "dual use" virulence factors in pathogenic environmental fung-the Cryptococcus neoformans paradigm. Current Opinnion in Microbiology, v.6: 332-7,2003.

Casadevall, A.; Steenbergen, J.N.; Nosanchuk, J.D. Ready made virulence ad dual use virulence factors in pathogenic environmental fungi the Cryptococcus neoformans paradigm. Current Opinion in Microbiology, v. 6, p. 332-7, 2003.

Casadevall, A; Rosas, A.L Nosanchuk, J.D; Melanin and virulence in Cryptococcus neoformans. Cur.Opin. In. Microbiol., 3:354-358,2000. 
Casadevall, A.; Perfect, J.R. Cryptococcus neoformans. Washington: ASM Press, $1998.541 \mathrm{p}$.

Cavalcanti, M. do A.S. Criptococose sistêmica endêmica pela variedade gattii no meio norte do Brasil. Teresina 1997 (Tese - Doutorado Universidade Federal do Piauí) in Lacaz CS, Porto E, Martins JEC, HeinsVaccari, Melo NT. Criptococose. In: Tratado de Micologia Médica Lacaz. São Paulo, SARVIER, 2002.

Chakrabarti, T.; Jatana, M.; Kumar, P.; Chatha, L.; Kaushal, A.; Padhye, A.A. Isolation of Cryptococcus neoformans var gattii from Eucalyptus camadulensis in India. J. Clin. Microbiol., v. 35, p. 3340-3342, 1997.

Chandler, F.H. et al. Color Atlas and Text of the histopathology of Mycotic Diseases.Chicago: Year Book Medical Publishers, 2002.

Chayakulkeeree, M.; Perfect, J.R. Cryptococcosis. Infect Dis Clin North America. V.20, p. 507-44, 2006.

Chen, S.; Sorrell, T; Nimmo, G. et al. Epidemiology and host- and varietydependent characteristics of infection due to Cryptococcus neoformans in Australia and New Zeland. Clin Infec Dis 2000; 31: 499- 508

Chun, C.D.; Brown, J.C.; Madhani, H.D.A major role for capsuleindependent phagocytosis inhibitory mechanisms in mammalian infection by Cryptococcus neoformans. Cell Host Microbe, v. 9, n.3, p. 243-51, mar, 2011.

Coelho, C.; Boca, A.; Casadevall,A.The Intracellular Life of Cryptococcus neoformans. Annu Ver Pathol, sep 2013.

Cogliati, M. Global Molecular Epidemiology of Cryptococcus neoformans and Cryptococcus gattii: An Atlas of the Molecular Types. Scientifica (Cairo), v.2013, p.675213, 2013.

Corrêa MPSC, Oliveira EC, Duarte RRBS, Pardal PPO, Oliveira FM, Severo LC. Criptococose em crianças no estado do Pará, Brasil. Rev Soc Bras Med Trop 1999; 32 (5): 505-508.

Costa, A.K.F. Análise fenotípica e molecular de cepas de Cryptococcus spp. obtidas de fontes ambientais e clínicas. Tese (Doutorado em Ciências Veterinárias), Faculdade de Veterinária, Universidade Estadual do Ceará, 2009.

Darze, C. et al. Características clínicas e laboratoriais de 104 casos de menigoencefalite criptocócica. Revista da Sociedade Brasileira de Medicina Tropical. V. 33. P.21-6, 2000. 
Delgado, A. C.N. et al. Human cryptococcosis: relation ship of environmental and clinical sttrains of Cryptococcus neoformans var. neoformans from urban and rural areas. Mycopathologia 159: 7-11, 2005.

Dharmshale SN, Patil SA, Gohil A, Chowdhary A, Oberoi C. Disseminated cryptococcosis with extensive cutaneous involvement in AIDS. Indian J Med Microbiol.2006; 24:228-30.

Dromer F, Mathoulin-Péllissier S, Fontanet A et al. Epidemiology of HIV associatedcryptococcosis in France (1985-2001): comparison of the pre- and post-HAART era. AIDS 2004; 18(3): 555-562.

Dupont, B. et al. Fungal Infections in AIDS Patients. Journal of Medical and Veterinary Mycology, V-30: 19-28,1992.

Cox, G.M.; Mcdade, H.C.; Chen, S.C.; Tucker, S.C.; Gottfredssom, M.; Wright, L.C.; Sorrell, S.D.; Leidich,A.; Casadevall,A.; Ghannoum, M.A; Perfect, J.R. Extracellular phospolipase activity is a virulence factor for Cryptococcus neoformans. Mol. Microbiol., v. 39, p.166-175, 2001.

De Jesus, D.M.; Nicola, A.M.; Chow, S-K.; Lee, I.R.; Nong, S.; Specht, C.A.; Levitz, S.M.; Casadevall, A. glucuronoxylomannan, galactoxylomannan and mannoprotein occupy spatially separate and discrete regions in the capsule. Virulence, v. 1, n.6, p.500-508,2010.

Ehrensing, E.R.; Saag, M.S.Criptococose. In: SAROSI, G.A.; DAVIES. S.F (Eds) Doenças Fúngicas do Pulmão. Ed. Revinter, São Paulo, 2001. Cap.7. 89-101.

Ellis, D.H.; Pfeiffer T.J. Natural habitat of Cryptococcus neoformans var gattii. J. Clin. Microbiol., v. 28, p. 1642-1644, 1990.

Fries, B.C.; Taborda, C.P.; Serfass, E.; Casadevall, A.; Phenotypic switching of Cryptococcus neoformans occurs in vivo and influences the outcome of infection. J. Clin Invest, v. 108, p. 1639-48, 2001.

Garcia- Hermoso D, Jandon G, Dromer F. Epidemiological evidence for dormant Cryptococcus neoformans infection. Journal Clinical Microbiology, 37: 3204-9, 1999.

Ghannoum, M.A. Potential role of phospholipases in virulence and fungal pathogenesis. Clinical Microbiology Reviews, v. 13, n. 1, p.122-143,2000.

Goldman DL, Khine $H$, Abadi $J$ et al. Serologic evidence for $C$. neoformansinfection in early childhood. Pediatrics 2001; 107(5): 66-71 
Gordon, S.B.; Read, R.C. Macrophage defences against respiratory tract infections.Br Med Bull, v. 61, p.45-61, 2002.

Granados, D.P.; Castaneda, E. Influence of climatic conditions on the isolation of members of the Cryptococcus neoformans species complex from trees in Columbia from 1992-2004.FEMS Yeast Res., v.6,p.636-644,2006.

Graybill, J.R.; Sobel, J.; Saag, M.; Horst, C.; Powderly, W.; Cloud, G.; Riser, L.; Hamil,R.; Dismukes, W. Diagnosis and management of increased intracranial pressure in patients with AIDS and cryptococcal meningitis. Clinical Infectious Diseases, v. 30, p. 47-54, 2000.

Guimarães M.D.C. Estudo temporal das doenças associadas à AIDS no Brasil, 1980-1999. Cad Saúde Pública 2000, 16 (sup 1): 21-36

Halliday, C.L.; Carter, D.A. Clonal reproduction and limited dispersal in an environmental population of Cryptococcus neoformans var. gattii isolates from Australia. J. Clin. Microbial., v. 41, p. 703-711,2003.

Hamil, R.J.; Sobel, J.D.; El-Sadr, W.; Johnson, P.C.; Graybill, J.R.; Javaly, K.; Barker, D.E. Comparison of 2 Doses of Liposomal Amphotericin B and Conventional Amphotericin B Deoxycholate for Treatment of AIDSAssociated Acute Cryptococcal Meningitis: A Randomized, Double-Blind Clinical Trial of Efficacy and Safety HIV/AIDS. Clin Infectious Diseases, v. 51 (2), p. 225-232, 2010.

Heitman, J.; Kozel, T.R.; Kwon- Chung, K.J.; Perfect, J.R.; Casadevall, A. Cryptococcus from human pathogen to model yeast. $2^{\text {nd }}$ ed. Washington: ASM Press, 2011. 620p.

Idnurm, A.; Bahn, Y.S.; Nielsen, K.; Lin, X.; Fraser, J.A.; Heitman, J. Deciphering the model pathogenic fungus Cryptococcus neoformans. Nature Revies Microbiology, v. 3.p. 753-64, 2005.

Janbon, G. Cryptococcus neoformans capsule biosynthesis and regulation. FEMS Yeast Research, v.4, p. 765-71, 2004.

Jenney A, Pandithage K, Fisher DA, Currie BJ. Cryptococcus infection in Tropical Australia.J ClinMicrobiol 2004; 42:3865-68

Karkowska-Kuleta, J.; Rapala-Kozik, M.; Kozik,A. Fungi pathogenic to humans: molecular bases of virulence of Candida albicans, Cryptococcus neoformans and Aspergillus fumigates. Acta Biochimica Polonica, v. 56, p. 211-24,2009.

Khan, Z. U.; Ahmad, S.; Hagen, F.; Fell, J.W.; Kowshik, T.; Chandy, R.; Boekhout, T. Cryptococcus randdhawai sp. nov., a novel anamorphic 
basidiomycetous yeast isolated from tree trunk hollow of Ficus religiosa (peepal tree) from New Delhi, India. Antonie van Leeuwenhoek, v. 97,p.253259,2010 .

Kidd, S. E.; Hagen, F.; Tscharke, R.L.; Huynh, M.; Bartlett, K.H.; Fyfe, M.; Macdougall, L.; Boekhout, T.; Kwon-Chung, K.J.; Meyer,W. A rare genotype of Cryptococcus gattii caused cryptococosis outbreak on Vancouver Island (British Columbia, Canada). Proc. Natl Acad Sci USA, v.101, p. 1725863,2004 .

Kim, K.S. Mechanisms of microbial transversal of the blood- brain barrier.Nat Rev Microbiol, v.6, n.8, p. 625-634, Aug 2008.

Kim, T.A. et al. HIV-1 Tat- mediated apoptosis in human brain microvascular endothelial cells. J Immunol, v. 170, n.5, p. 2629-37, Mar 2003.

Knoke, M.; Schwesinger,G. One hundred years ago: the history of cryptococcosis in Greifswald. Medical mycology in the nineteenth century.Mycoses, v. 37,p. 229-233,1994.

Kon, A.S.; Grumach, A.S.; Colombo, A.L.; Penalva, A.C.O; Wanke, B.; Telles, F.Q.; Severo, L.C.; Aranha, L.F.; Lazera, M.S.; Resende, M.R.; Salmito, M.A.; Shikanai- Yasuda, M.A.; Moretti, M.L.; Ferreira, M.S.; SilvaVergara, M.L.; Andrade, N.M.P.; Trabasso, P.M.; Rinaldo, P.; Martinez, R.; Ponzio, V. Consenso em Criptococose. Rev Soc Bras Med Trop. V.41, p. 524-44, 2008.

Kronstad J.W; Attarian R; Cadieux B; Choi J; D'Souza CA; Griffiths E.J, et al. Expanding fungal pathogenesis: Cryptococcus breaks out of the opportunistic box. Nat Rev Microbiol 2011 Mar; 9(3):193-203.

Kurtzman, C.P.; Fell, J.W.; Boekhout, T. Cryptococcus. In: _. The yeasts: a taxonomic study . 5 th ed. New York: ACM Press, 2011. P. 16611662.

Kwon-Chung, K.J.A new genus, Filobasidiella, the perfect state of Cryptococcus neoformans.Mycologia, V. 67, p. 1197-1200,1975.

Kwon-Chung, K.J.; Boekhout,T.; Fell, J.W.; Diaz, M. Proposal to conserve the name Cryptococcus gattii against $C$. hondurianus and $C$. bacillisporus (Basidiomycota, Hymenomycetes, Tremellomycetidae). Taxon, V. 51, p. 804806, 2002.

Kwon- Chung, K. J.; Varma, A. Do major species concepts support one, two or more species within Cryptococcus neoformans? FEMS Yeast Research v.6. p. $574-587,2006$. 
Lacaz, C.S.; Negro, G. Drogas antifúngicas: Terapêutica das micoses. In: Lacaz, C.S.; Porto, E.; Martins, J. E. C. Micologia médica fungos, actinomicetos e algas de interesse médico. São Paulo: Savier, 1991

Lacaz, C.S.; Porto, E.; Martins, J.E.C.; Heins-Vaccari, E.M.; Melo, N.T. Tratado de Micologia Médica. 9 ed. São Paulo: Savier; 2002.

Larsen, R.A.; Leal, M.A.; Chan, L.S. Fluconazol compared with amphotericin $B$ plus flucytosine for Cryptococcal meningitis in AIDS: a randomized trial. Ann Intern Med, v. 113, p. 183-187, 1990.

Larsen, R.A.; Bozzette, S.A.; Jones, B.E. et al. Fluconazol combined with flucytosine for treatment of cryptococcal meningitis in patients with AIDS. Clin Infect Dis, v. 19, p. 741-745, 1994

Lazéra, M.S.; Igreja, R.P.; Wanke, B. Criptococose. In: Sidrim, J. J. C.; Rocha, M .F. G. Micologia médica à luz de autores contemporâneos. Rio de Janeiro: Guanabara Koogan, 2004. Cap.24, p.252-264.

Lazera, M.S.; Gutierrez-Galhardo, M.C.; Cavalcanti, M.A.S.; Wanke, B. Criptococose. In: JR Coura, organizador. Dinâmica das Doenças Infecciosas e Parasitárias. 1 st Ed. Rio de Janeiro: Guanabara Koogan; v. 11.p. 1223-35, 2005.

Lazera, M.S.; Cavalcanti Salmito, M.A.; Londero,A.T.; Trilles,L.; Nishikama, M.M.; Wanke,B. Possible primary ecological niche of Cryptococcus neoformans. Med. Mycol.; v. 38, p. 379-383,2000.

Lin, X.; Heitman, J.The biology of the Cryptococcus neoformans Species Complex.Annual Review of Microbiology,v.60, p.69-105, 2006.

Leal AL, Faganello J, Fuentefria AM, Boldo JT, Bassanesi MC, Vainstein MH. Epidemiological Profile of Cryptococcal Meningitis Patients in Rio Grande do Sul, Brazil. Mycopathologia 2008; 166:71-75.

Lee, S.J., Choi, H,K., Son, J., Kim, K.H, Lee, S.H. Cryptococcal Meningitis in Patients with or without Human Immunodeficiency Virus: Experience in a Tertiary Hospital. Yonsei Med J, v. 52(3):482-487, 2011

Lindenberg ASC, Chang MR, Paniago AMM, Lazera MS, Moncada PMF, Bonfim GF, et al. Clinical and epidemiological features of 123 cases of cryptococcosis in Mato Grosso do Sul, Brazil. Rev Inst Med Trop S Paulo. 2008; 50 (2): 75-78.

Lindsley, M.D.; Mekha, N.; Baggett, H.C.; Surinthong, Y.; Autthateinchai, R.; Sawatwong, P.; Harris, J.R.; Park, B.J.; Chiller, T.; Balajee, S.A.; 
Poonwan, N. Evaluation of a Newly Developed Lateral Flow Immunoassay for the Diagnosis of Cryptococcosis. Clinical Infectious Diseases.V.53 (4), p. 321-325, 2011.

Littman, M.L.; Zimmerman, L.E. Cryptococosis: Torulosis or European blastomycosis. New York: Grune and Stratton., 1956.p. 303-307,1995.

Liu, O.W.; Chun, C.D.; Chow, E.D.; Chen, C.; Madhani, H.D.; Noble, S.M. Systematic genetic analysis of virulence in the human fungal pathogen Cryptococcus neoformans. Cell, v.135, p. 174-188, 2008.

Livramento, J.A, Machado L.R, Nóbrega J.P.S et al. CSF in 85 patients with AIDSand CNS cryptococcosis.ArqNeuro-Psiquiatr (São Paulo) 1992; 50 (4): 491-496

Luberto, C.; Martinez-Marino, B.; Taraskiewicz, D.; Bolanos, B.; Chitano, P.; Toffaletti, D.L, Cox, G,M, Perfect, J.R.; Hannun, Y.A, Balish, E.; Del Poeta, $M$. Identification of App 1 as a regulator of phagocytosis and virulence of Cryptococcus neoformans.Journal of Clinical Investigation, 112: 1080$94,2003$.

Lupetti, A.; Nibbering, P. H.; Campa, M.; Tacca, M. D.; Danesi, R. Molecular targeted treatments for fungal infections: the role of drug combinations. Trend in Mol. Med., v. 9, n. 6, jun. 2003.

Lupo,P., Chang, Y.C., Kelsall,B.L., Farber,J.M., Pietrella,D., Vecchiarelli,A., Leon,F., Kwon-Chung, K.J. The presence of capsule in Cryptcoccus neoformans influences the gene expression profile in dendritic cells during interaction with the fungus. Infect. Immun. 76: 1581-1589, 2008.

Ma H; May Rc. Virulence in Cryptococcus species.Advances in Applied Microbiology, 67: 131-90, 2009.

Martinez, L.R.; Garcia- Rivera,J.; Casadevall, A. Cryptococcus neoformans var. neoformans (serotype D) strains are more susceptible to heat than $C$. neoformans var. grubii (serotype A) strains. J Clin Microbiol, v.39 (9), p. 3365-67, 2001.

Martins LMS. Epidemiologia da Criptococose em crianças e diversidade da Cryptococcusneoformans no meio norte do Brasil. 2003 (Tese - Mestrado Fundação Oswaldo Cruz).

McClelland EE, Hobbs LM, Rivera J, Casadevall A, Potts WK, et al. (2013) The Role of Host Gender in the Pathogenesis of Cryptococcus neoformansinfections. PLOS ONE 8(5): e63632. doi:10.1371/journal.pone.0063632 
Menezes, E.A.;Monteiro, M.N.R.; Angelo, M.R.F. et al. Cryptococcus neoformans causing meningitis in AIDS patients. Rev Soc Bras Med Trop 2002; v.35(5): 537-539.

Meyer, A.; Castaneda, A.; Jackson, S.; Huynh, M.; Castaneda, E. Molecular typing of Ibero American Cryptococcus neoformans isolates. Emerg Infectious Diseases, v.9, p.189-95, 2003.

Mezzari, A., Wliebbelling, A. M. P., Freitas, G.S.O., May, G.G., Albe, G.C., et al. Criptococose em um Hospital Público de Porto Alegre: dados epidemiológicos. Journal of Infection Control.V.2 (3), p. 135-139, 2013.

Millogo A, Ki-Zerbo GA, Andonaba JB, Lankoandé D, Sawadogo A, Yameogo I et al. Cryptococcal meningitis in HIV-infected patients at BoboDioulasso hospital (Burkina Faso). Bull SocPatholExot 2004; 97:119-21.

Ministério da Saúde, Departamento de DST, AIDS e Hepatite Virais, Portal sobre AIDS, doenças sexualmente transmissíveis e hepatites virais. AIDS no Brasil.Disponível em: URL: http://www.AIDS.gov.br/ pagina/AIDS-no-Brasil. 2015.

Ministerio da Saúde. Vigilância Epidemiológica da Criptococose. Brasília, 2012.

Mirza, S.; Phelan, M.; Rimland, D.; Graviss, E.; Hamil, R.; Brandt, M.E.; Gardner, T.; Sattah, M.; De Leon, G.P.; Baughman, W.; Hajjeh, R.A. The changing epidemiology of cryptococcosis: An update from population based active surveillance in 2 large metropolitan areas, 1992-2000. Clinical Infectious Diseases, v. 36, p. 789-794, 2003.

Mitchell D.H, Sorrell TC, Allworth AM, Heath CH, McGregor AR, et al. (1995) Cryptococcal disease of the CNS in immunocompetent hosts: influence ofcryptococcal variety on clinical manifestations and outcome. Clin Infect Dis 20:611-616.

Mitchell T.G, Perfect JR. Cryptococcosis in the era of AIDS - 100 years after the discovery of Cryptococcus neoformans.ClinicalofMicrobiologyReview.V.8(4), p. 515-548,1995

Montenegro, H.; Paula, C.R. Environmental Isolation of Cryptococcus neoformans var gattii and $C$. neoformans var. neoformans in the city of São Paulo, Brazil.Med. Mycol., v. 38, p. 385-390, 2000.

Moreira, T. A. et al. Criptococose: estudo clínico- epidemiológico, laboratorial e das variedades do fungo em 96 pacientes. Revista da Sociedade Brasileira de Medicina Tropical. Uberaba, vol.39.p.255-258,2006. 
Moretti, M.L. et al. consenso em Criptococose 2008. Revista da Sociedade Brasileira de Medicina Tropical. V. 41, p.695, 2008.

Murakawa GJ, Kerschmann R, Berger T. Cutaneous cryptococcus infection and AIDS. Report of 12 cases and review of literature. Arch Dermatol. 1996:132-5.

Mussini C, Pezzotti P, Miro JM, et al. Discontinuation of maintenance therapy for cryptococcal meningitis in patients with AIDS treated with highly active antiretroviral therapy: an international observational study. Clin Infect Dis. V.38: $565-571,2004$

Nadrous, H. F.; Antonios,V.S.; Terrell, C.L.; Ryu,J.H. Pulmonary cryptococcosis in nonimmunocompromised patients. Chest. 2003;124(6):2143-7. Comment in: Chest. 2003;124(6):2049-51.

Nishikawa, M.M., et al. Serotyping of 467 Cryptococcus neoformans isolates from clinical and environmental sources in Brazil: analysis of host and regional patterns. JournalClinicalMicrobiology. 41: 73-77.2003.

Noverr, M.C.; Cox, G.M.; Perfect, J.R.; Huffnagle, G.B. Role of PLB1 n pulmonary inflammation and cryptococcal eicosanoid production.Infect. Immun., v. 71, p. 1538-1547,2003.

Odds, F. C.; Brown A. J.P.; Gow, N.A.R. Antifungal agents: mechanisms of action. Tren.Microb., v. 11, n. 6, p. 272-279, 2003.

Odom, A.; Muir, S.; Lim, E.; Toffaletti, D.L.; Perfect, J.R.; Heitman, J. Calcineurin is required for virulence of Cryptococcus neoformans. EMBO Journal, v. 16, p. 2576-89, 1997.

Olszewski, M.A. et al. Urease expression by Cryptococcus neoformans promotes microvascular sequestration, thereby enhancing central nervous system invasion. Am J Pathol, v. 164, n.5, p. 1761-71, may, 2004.

Ong E.L. Common AIDS-associated opportunistic infections. Clin Med 2008; 8:539-43.

Pappalardo, M.C.S.M.; Melhem, M.S.C. Cryptococcosis: a review of the Brazilian experience for the disease. Revista do Instituto de Medicina Tropical de São Paulo, v. 45, p.299-305,2003.

Park B.J, Wannemuehler KA, Marston BJ, Govender N, Pappas PG, Chiller TM. Estimation of the current global burden of cryptococcal meningitis among persons living with HIV/AIDS. AIDS2009; 23 (4):525-530. 
Passoni, L.F.C.; Wanke, B.; Nishikama, M.M.; Lazera, M.S. Cryptococcus neoformans isolated from human dwellings in Rio de Janeiro, Brazil: an analysis of the domestic environment of AIDS patients with and without cryptococccosis. Med. Mycol., v. 36, p.305-11, 1998.

Pauw, B.E. New antifungal agents and preparations. International Journal of Antimicrobial Agents, Nijmegen, v.16, p. 147-150, 2000.

Perfect, J.R.; Dismukes, W.E.; Dromer, F., Goldman, D.L.; Graybill, J.R.; Hamill, R.J.; Harrison, T.S.; Larsen, R.A.; Lortholary, O.; Nguyen,,M.H.; Pappas, P.G.; Powderley, W.G.; Singh, N.; Sobel,J.D.; Sorrell, T. C. Clinical Practice Guidelines for the Management of Cryptococcal Disease: 2010 Update by the Infectious Diseases Society of America. Clinical Infectious Diseases, v.50, p. 291-322, 2010.

Perfect, J.R. Cryptococcus neoformans: A sugar-coated killer with designer genes. FEMS Immunol Med Microbiol,n. 45, p.395-404,2005.

Perfect, J.R.; Casadevall,A. Cryptococcosis.Infectious Disease Clinics North America, v.16, p. 837- 874,2002.

Perfect, J.R.Cryptococcus neoformans. In: Mandell, G.L.; Bennett, J.E.; Dolin,R. Principles and Practice of Infectious Diseases. Philadelphia: Elsevier,2010. cap. 263,p. 3287-3303.

Perfect, J.R. Cryptococcus neoformans: the yeast that likes it hot. FEMS Yeast Res 2006, v. 6(4), p. 463-8.

Pfaller, M.A.; Mcginnis, M.R.; Anaissie, E.J. Clinical Mycology. $2^{\text {nd }}$ ed. New York:Churcill Livingstone, 2009. 688 p.

Pfeiffer, T.J.; Ellis, D. Environmental isolation of Cryptococcus neoformans var. gattii from Eucalyptus tireticornis.J. Med. Vet. Mycol., v. 30, p. 407408,1992.

Pfeiffer, T.; Ellis, D. Environmental isolation of Cryptococcus neoformans var. gattii from California. J. Infect. Dis., v. 163, p. 929-930,1991.

Pinto Junior, V.L. Criptococose associada à AIDS. Análise da casuística do Instituto de Pesquisa Clínica Evandro Chagas - Fiocruz - entre 1987 e 2002. Instituto Oswaldo Cruz, Fiocruz, Dissertação de Mestrado, 2003.

Pongsai, P.; Atamasirikul, K.; Sungkanuparph, S. The role of serum cryptococcal antigen screening for the early diagnosis of cryptococcosis in HIV- infected patients with different ranges of CD4 cell counts. Journal of Infection, v. 60, n.6, p. 474-7, 2010 
Portela, M.B.; Souza, I.P.; Abreu, C. M.; Bertolini, M.; Holandino, C.; Alviano, C.S.; Santos, A.L.; Soares, R.M. Effect of serine- type protease of Candida spp. Isolated from linear gingival erythema of HIV- positive children: critical factors in the colonization. Journal of Oral Pathology Medicine, v. 39, n.10, p.753-760, 2010.

Prado, M. et al. Mortality due to systemic mycoses as a primary cause of death or in association with AIDS in Brazil: a review frow 1996 to 2006. Mem Inst Oswaldo Cruz, V.104, n.3, p. 513-21, May 2009.

Rambach, G.; Dum, D.; Mohsenipour, I.; Hagleitner, M.; Wurzner, R.; LassFlorl, C.; Speth, C. Secretion of a fungal protease represents a complement evasion mechanism in cerebral aspergillosis. Molecular Immunology, v. 47, p. 1438-49, 2010.

Refojo, N.; Perrotta, D.E.; Brudny, M.; Abrantes, R.; Hevia, A.I.; Davel,G. Isolation of Cryptococcus neoformans and Cryptococcus gattii from trunk hollows of living trees in Buenos Aires City, Argentina. Med. Mycol., v. 47, p. 177-184, 2009.

Rodrigues, M. L. et al. Extracellular vesicles produced by Cryptococcus neoformans contain protein componets associated with virulence. Eukaryot Cell, v. 7, n. 1, p.58-67, jan 2008.

Robinson, R.A.; Bauer, M.; Leal, M.A.E.; Evans, S.G.; Holtom, P.D.; Diamond, D.M.; Leedom, J.M.; Larsen, R.A. Early Mycological Treatment Failure in AIDS-Associated Cryptococcal Meningitis. Clin Infectious Diseases, v.28(1), p. 82-92, 1999.

Rosa e Silva, L.K. Identificação de genes regulados pela temperatura na levedura patogênica Cryptococcus neoformans. Dissertação de mestrado, Universidade Federal do Rio Grande do Sul, Programa de Pós Graduação em Biologia Celular e Molecular, 49p.,2006

Rosa e Silva, L.K.; Staats, C.C., Goulart, L.S., Morello, L.G., Pelegrinelli Fungaro, M.H., Schrank, A., Vainstein, M.H. Identification of novel temperature regulated genes in the human pathogen Cryptococcus neoformans using representational difference analysis. Research Microbiology, 159:221-9, 2008.

Rozenbaum, R.; Gonçalves, A.J.; Wanke, B.; Vieira, W. Cryptococcus neoformans var gattii in Brazilian AIDS patient.Mycopathologia, v. 112, p.3334,1990 .

Rozembaum R, Gonçalves AJ. Clinical epidemiological study of 171 cases of cryptococcosis. ClinlnfectDis 1994 Mar; 18(3): 369-80 
Ruma-Haynes, P.; Brownlee, A.G.; Sorrel, T.C.A rapid method for detecting extracellular proteinase activity in Cryptococcus neoformans and a survey of 63 isolates.J. Med. Microbiol., v. 49, p.733-737,2000

Saag, M.S.; Graybill, R.V.; Larsen, R.A.; Pappas, P.G.; Perfect, J.R.; Powderly, W.G.; Sobel, J.D.; Dismukes, W.E. Practice Guidelines for the Management of Cryptococcal Disease. Clinical Infectious Disease. V. 30, p. 710-18,2000.

Sabiiti, W.; May, R.C. Mechanisms of infection by the human fungal pathogen Cryptococcus neoformans. Future Microbiology, p. 1297-1313, 2012

Santangelo, R. et al. Role of extracellular phospholipases and mononuclear phagocytes in dissemination of Cryptococcossis in a murine model. Infect Immun, v.72, n.4, p 2229-39, Apr, 2004

Santos LO. Criptococose no estado do Amazonas: estudo de 75 casos diagnosticados na Fundação de Medicina Tropical/FMT/IMTM, Manaus, AM (1988-1998), Dissertação de Mestrado, Instituto Oswaldo Cruz-Fiocruz, Rio de Janeiro 154 pp. 2000.

Severo, C; Oliveira, F.M; Silva, V.B. Diferenças Clínicas, epidemiológicas e ecológicas entre as duas variedades de Cryptococcus neoformans. Ver. Médica Sta Casa, 9: 1672-1686,1998.

Severo, C, et al. Capítulo 3: Criptococose pulmonar. Jornal Brasileiro de Pneumologia. Vol. 35, n.11, p. 1136-1144,2009.

Shi, M. et al. Real-time imaging of trapping and urease-dependent transmigration of Cryptococcus neoformans in mouse brain.J Clin Invest, v. 120, n.5, p. 1683-93, May 2010.

Siafakas, A.R.; Wright, L.C.; Sorrell, T.C.; Djordjevic, J.T. Lipid rafts in Cryptococcus neoformans concentrate the virulence determinants phospholipase B1 and $\mathrm{Cu} / \mathrm{Zn}$ superoxide dismutase. Eukaryot.Cell.; v.5, p.488-498,2006.

Sidrim, J.J.C. Micoses oportunistas. In: Sidrim, J.J.C.; Moreira, J.L.B. Fundamentos Clínicos e Laboratoriais da Micologia Médica. Rio de Janeiro: Guanabara Koogan, 1999. Cap.15, p.179-182.

Sidrim, JJC, Rocha MFG. Micologia Médica à Luz de Autores Contemporâneos. Rio de Janeiro, R.J.: Editora Guanabara Koogan LTDA; 2010.

Silva B.K.S. Caracterização de linhagens do complexo Cryptococcus neoformans isoladas de pacientes atendidos na Fundação de Medicina 
Tropical do Amazonas. Dissertação de Mestrado. Manaus: Universidade do Estado do Amazonas 2009: 92 pp.

Singh N, Alexander BD, Lortholary O, Dromer F, Gupta KL, John GT, et al. Cryptococcus neoformans in organ transplant recipients: impact of calcineurin- inhibitor agents on mortality. J. Infect Dis.2007; 195: 756-64.

Soares, M.C.B.; Paula, C.R.; Dias, A.L.T.; Caseiro, M.M.; Costa, S.O.P. Enviromental Straits of Cryptococcus neoformans variety grubbii in the city of Santos, SP, Brazil. Revista do Instituto de Medicina Tropical de São Paulo, v. 47, p. 31-37,2005.

Sloan, D.J; Parris, V. Cryptococcal meningitis: epidemiology and therapeutic Options. Clinical Epidemiology.V.6. p. 169-182. 2014.

Soares, D.A.; Andrade, R.V.; Silva, S.S.; Bocca, A.L.; Soares, F.S.M.; Petrofeza, S. Extracellular Paracoccidioides brasiliensis phospholipase B involvement in alveolar macrophage interaction. BMC Microbiology, v.10, p.241, 2010.

Soares, L.R.; Siqueira, L.B.; Silva, M.S. Meningite criptocócica na gravidez: revisão de aspectos terapêuticos. FEMINA, V.39, p. 325-328, 2011.

Steenbergen, J.N.; Casadevall, A.The origin and maintenance of virulence for the human pathogenic fungus Cryptococcus neoformans. Microbes and Infection, v. 5, p. 667-675, 2003.

Stevens, D. A. Diagnosis of fungal infections: Current status. Journal of Antimicrobial Chemotherapy, V. 49 Sup.1, p. 11-19, 2002.

Swinne-Desgani, D. Cryptococcus neoformans of saprophytic origin.Sabouraudia, v. 13, p. 303-308,1975.

Tintelnot, K., Schar, G., Polar, A. Epidemiological data of cryptococcosis in Áustria, Germany and Switzerland: part of yhe ECMM survey in Europe. European Confederation of Medical Mycology.Mycoses 2001; 44 (9-10): 34550.

Trilles L, Lazéra MS, Wanke B et al. Regional pattern of the molecular types of Cryptococcus neoformans and Cryptococcus gattii in Brazil. Mem Inst Oswaldo Cruz 2008; 103:455-462

Tucker, S.C.; Casadevall, A. Replication of Cryptococcus neoformans in macrophages is accompanied by phagosomal permeabilization and accumulation of vesicles containing polysaccharide in the cytoplasm. Proc Natl Acad Sci USA, v. 99, n.5, p. 3165-70, mar, 2002. 
Van Duin, D.; Casadevall, A.; Nosanchuk, J.D. Melanization of Cryptococcus neoformans and Histoplasma capsulatum reduces their susceptibilities toamphotericin B and caspofungin. Antimicrob Agents Chemother, v. 46, n.11, p.3394-400, nov, 2002.

Velagapudi, R. et al. Spores as infectious propagules of Cryptococcus neoformans. Infect Immun, v.77,n.10, p. 4345-55, oct 2009.

Vibhagool A, Sungkanuparph S, Mootsikapun P, et al. Discontinuation of secondary prophylaxis for cryptococcal meningitis in human immunodeficiency virus-infected patients treated with highly active antiretroviral therapy: a prospective, multicenter, randomized study. Clin Infect Dis. 2003;36:1329-1331.

Vilcins, I.; Krockenberger, M.B.; Agus, H.; Carter, D.A. Environmental sampling for Cryptococcus neoformans var. gattii from the Blue Mountains National Park, Sidney, Australia. Med. Mycol., v. 41, p. 383-390,2002.

Voelz, K., May, R.C. Cryptococcal interactions with the host immune system. Eukaryot Cell. V.9, p. 835-846, 2010.

Wasan, K.M.; Conklin, J.S. Enhanced amphotericin B nephrotoxicity in intensive care patients with elevated levels of low- density lipoprotein cholesterol. Clin. Infect. Dis. V.24, p.78-80,1997.

World Health Organization.Rapid Advice: diagnosis, Prevention and Management of Cryptococcal disease in HIV-Infected Adults, Adolescentes and Children. Geneva: WHO; 2011.

Zaragoza, O.; Rodrigues, M.L.; De Jesus, D.M.; Frases, S.; Dadachova, E.; Casadevall, A. The capsule of the fungal pathogen Cryptococcus neoformans.Adv Appl. Microbiol.; v. 68, p.133-216,2009.

Zaragoza, O.; Casadevall, A. Experimental modulation of capsule size in Cryptococcus neoformans.Biological Procedures Online, v.6, n.1, p.1015,2004 .

Zaragoza, O. et al. Capsule enlargement in Cryptococcus neoformans confers rsistence to oxidative stress suggesting a mechanism for intracellular survival. Cell Microbiol, v. 10, .10, p.2043-57, oct,2008. 


\section{ANEXOS}

\subsection{QUESTIONÁRIO}

Projeto: CARACTERÍSTICAS CLÍNICAS, EPIDEMIOLÓGICAS E LABORATORIAIS DA CRIPTOCOCOSE NO DISTRITO FEDERAL NO PERÍODO DE 2006 A 2013.

Ficha:

1)INICIAIS:

2) PRONT:

2)DATA DE NASC:

3)SEXO:

4)NATURALIDADE:

5)PROCEDÊNCIA

6)OCUPAÇÃO:

7)UNIDADE DE ATENDIMENTO:

8) DATA DE DIAGNÓSTICO:

9)MANIFESTAÇÕES CLÍNICAS:
( ) Cefaléia
( ) Febre
( ) Vômitos
( ) Convulsão
( ) Desorientação
( ) Tontura
( ) Rigidez de Nuca
( ) Coma
( )Tosse
( ) dor pleurítica 
( ) Sudorese

( ) Emagrecimento

( ) Lesão de pele

( ) Outras:

DIAGNÓSTICO LABORATORIAL:

10)EXAME DIRETO POSITIVO: ( ) SIM NÃO

11)MATERIAL:（）LÍQUOR （）ESCARRO （） OUTROS

12)CULTIVO POSITIVO DE ESPÉCIMES CLÍNICOS :

( ) SIM （）NÃO

13)MATERIAL:

（）LÍQUOR （）SANGUE （）URINA（）ESCARRO

( ) LAVADO BRONCOALVEOLAR （） FRAGMENTOS DE BIÓPSIA

14)PESQUISA DE ANTÍGENO CAPSULAR POSITVO

( ) SIM ( ) NÃO

15)MÉTODO:

( ) LÁTEX

( ) FITA (imunocromotografia)

COMORBIDADES/ FATORES DE RISCO

16) HIV: ( ) SIM ） NÃO

17)LINFÓCITO TCD4 ( NÚMERO/MM3):

18) CARGA VIRAL (LOG):

19) DATA DO EXAME:

20) CORTICOTERAPIA:

( ) SIM N NÃO 
21) OUTROS FÁRMACOS IMUNOSUPRESSOR:

( ) SIM ( ) NÃO

22) DOENÇA HEPÁTICA:

( ) SIM ( ) NÃO

23) DIABETES:

( ) SIM ( ) NÃO

24) Insuficiência renal:

( ) SIM ( ) NÃO

25) DOENÇA AUTO IMUNE:

( ) SIM ( ) NÃO

26) GRAVIDEZ:

( ) SIM ( ) NÃO

27) DOENÇA NEUROLÓGICA

( ) SIM ( ) NÃO

28) NEOPLASIAS:
( ) SIM
( ) NÃO

29) OUTRAS COMORBIDADES:

( ) SIM ( ) NÃO

ESPECIFICAR:

30) CONDUTA TERAPÊUTICA

( ) ANFOTERICINA- DEOXICOLATO

( ) ANFOTERICNA- LIPOSSOMAL

( )FLUCONAZOL

( ) ITRACONAZOL

( ) VORICONAZOL

( ) 5- FLUOCITOSINA 
31) EVOLUÇÃO:

Alta hospitalar:( ) SIM

（ ) NÃO

ÓBITO:( ) SIM

( ) NÃO 
9.2. PARECER DO COMITÊ DE ÉTICA 


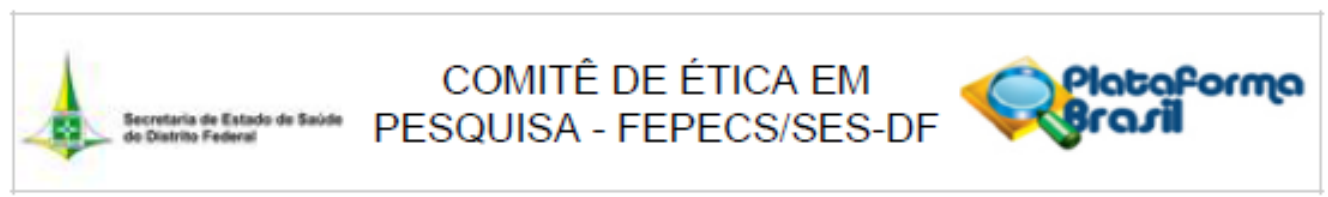

\section{PARECER CONSUBSTANCIADO DO CEP}

\section{DADOS DO PROJETO DE PESQUISA}

Título da Pesquisa: CARACTERÍSTICAS CLÍNICAS, EPIDEMIOLÓGICAS E LABORATORIAIS DA CRIPTOCOCOSE NO DISTRITO FEDERAL NO PERÍODO DE 2006 A 2013.

Pesquisador: juliana soares de frança

Área Temática:

Versão: 1

CAAE: 35795814.2 .0000 .5553

Instituição Proponente:Secretaria de Estado de Saúde do Distrito Federal / FEPECS/ SES/ DF

Patrocinador Principal: Financiamento Próprio

\section{DADOS DO PARECER}

Número do Parecer: 799.605

Data da Relatoria: 22/09/2014

\section{Apresentação do Projeto:}

A criptococose é uma micose emergente e cosmopolita causada pelas leveduras capsuladas Cryptococcus neoformans e Criptococcus gattii, onde a

primeira possui caráter predominantemente oportunista, causando um milhão de casos de meningoencefalite por ano em pacientes com AIDS em

todo o mundo, com aproximadamente 625.000 óbitos. C.gattii é o responsável por micose sistêmica em indivíduos aparentemente normais,

endêmico nas regiões Norte (Amazônia) e Nordeste do Brasil, incluído o semiárido, atingindo crianças, adolescentes e adultos jovens, HIVnegativos.

No Brasil, a letalidade pelos dois agentes ainda é inaceitavelmente elevada, de $45 \%$ a $65 \%$ em casos de meningite, seja associada ou

não à Aids. $A$ emergência de criptococose por $C$. gattii evidencia-se em dados mundiais robustos sobre a incidência crescente desta micose

primaria, através de surtos em humanos e animais e clara expansão geográfica no continente americano. No Brasil faltam estudos epidemiológicos

sistematizados sobre a criptococose, cujo diagnostico tardio é marcante. Esta proposta tem por objetivo promover o levantamento do perfil

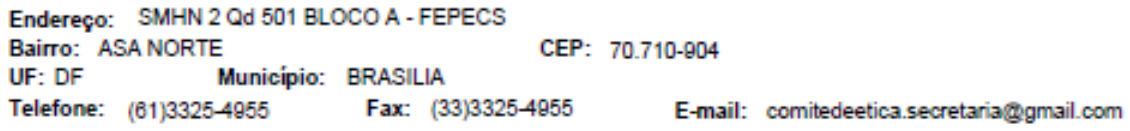




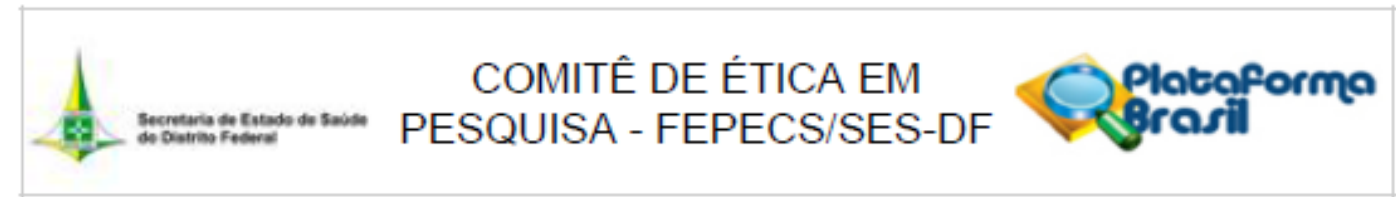

Continuaç̧̃o do Parecer. 799.605

epidemiológico desta micose no Distrito Federal de forma sistemática. Trata-se de um estudo descritivo de base hospitalar de pacientes com

diagnóstico laboratorial de criptococose. A captação de indivíduos ocorrerá através do levantamento de dados laboratoriais e hospitalares e abrange

indivíduos com criptococose primária (criptococose gattii) e criptococose oportunística, com os subgrupos de doença associada: Aids, transplante de

órgãos, diabetes, etc. Será utilizado instrumento de Coleta de dados padronizado

Objetivo da Pesquisa:

Objetivo Primário:

Descrever os casos de criptococose entre os anos de 2006 a 2013, estudando as características clínicas, epidemiológicas, diagnósticas e

terapêuticas.

Objetivo Secundário:

Determinar as características clínicas e laboratoriais da criptococose em hospedeiro com e sem fatores predisponentes associados no DF. Estudar o

perfil epidemiológico e a evolução clínica dos casos de criptococose primária e oportunística no Distrito Federal, identificando fatores determinantes

associados aos diversos desfechos clínicos. Caracterizar formas clínicas e distribuição geográfica da Criptococose no Distrito Federal

Avaliação dos Riscos e Benefícios:

Riscos:

Considerando que todo estudo envolve riscos, o presente estudo assume como principal risco a extrapolação indevida dos dados coletados para

além dos propósitos estabelecidos pela pesquisa configurando-se como um risco para a amostra.

Benefícios:

Melhoria do conhecimento epidemiológico sobre a doença no Distrito Federal o que poderá viabilizar o diagnóstico precoce da doença, manejo

terapêutico e por consequência o prognóstico dos pacientes acometidos

Comentários e Considerações sobre a Pesquisa:

4.1: Delineamento do Estudo: Estudo clínico epidemiológico descritivo, para levantamento e caracterização dos casos de criptococose no Distrito

Federal, tendo como base os registros hospitalares (prontuários e bases laboratoriais) de pacientes

Endereço: SMHN 2 Qd 501 BLOCO A - FEPECS

Bairro: ASA NORTE

UF: DF Município: BRASILIA

CEP: $70.710-904$

Telefone: (61)3325-4955

Fax: $(33) 3325-4955$

E-mail: comitedeetica.secretariaggmail.com

Pagins 02 de of 


\section{PESQUISA - FEPECS/SES-DF}

Continuaçăo do Parecer. 799.605

com diagnóstico de criptococose e os dados do

Sistema de Informação da Vigilância Epidemiológica. O período proposto para esse estudo compreenderá os anos de 2006 a 2013. 4.2: Coleta de

dados: Os dados clínico-epidemiológicos e laboratoriais serão obtidos após aprovação do projeto pelo Comitê de Ética; a partir da revisão de

prontuários dos pacientes com diagnóstico de criptococose, atendidos em todas as unidades hospitalares do Distrito Federal por meio dos seguintes

instrumentos: registros hospitalares disponiveis através do prontuário eletrônico ou impresso; bases eletrônicas do Laboratório Central (LACEN)

bases eletrônica disponivel na rede SUS de saúde do Distrito Federal (TRACK CARE); Será utilizado questionário de pesquisa (ANEXO A) para

coleta das variáveis a serem analisadas. 4.3: População do Estudo Serão incluidos indivíduos de ambos os sexos e todas as faixas etárias, com

diagnóstico clínico - laboratorial de criptococose primária ou associada a co-infecção pelo HIV ou a outros fatores predisponentes - doenças

malignas, transplantes, diabetes, uso de corticóide e/ou outros imunossupressores e imunobiológicos (rituximab, etc), cirrose, doenças inflamatórias

crônicas, tuberculose, gravidez e outros). Em vista do fato de que a criptococose não é de notificação compulsória no país, a estimativa da

população amostral baseou-se em diversas fontes de dados chegando ao número de 300 casos/ ano no Brasil.

Consideraçôes sobre os Termos de apresentação obrigatória:

Foram analisados os Termos de Apresentação Obrigatoria e considerados adequados,a pesquiasdora solicita dispensa do TCLE, considerando sa caracteristicas da pesquisa-Aceito

Recomendaçöes:

Apresentar Relatorio com o desenvolvimento do Projeto.

Conclusões ou Pendências e Lista de Inadequações:

Projeto aprovado

Situação do Parecer:

Aprovado

Necessita Apreciação da CONEP:

Não

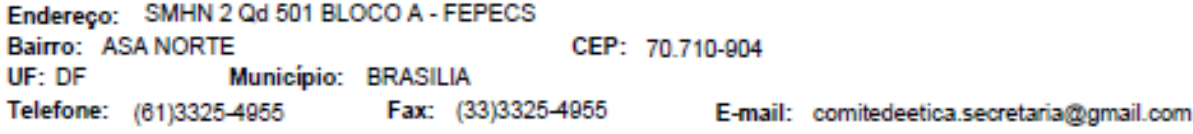




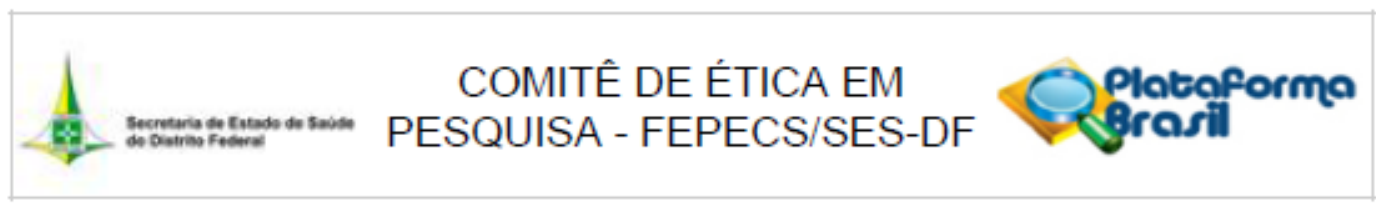

Continuaçăo do Parecer. 799.605

Considerações Finais a critério do CEP:

BRASILIA, 22 de Setembro de 2014

Assinado por:

LUIZ FERNANDO GALVÄO SALINAS

(Coordenador) 